\author{
University of Szeged \\ Department of Image Processing and Computer \\ Graphics
}

\title{
A Pixel-based Discrete Tomographic Technique and Its Applications
}

\author{
Ph.D. Thesis
}

by

Zoltán Kiss

Thesis advisor

Attila Kuba, Ph.D.

\author{
University of Szeged \\ Ph.D. School in Computer Science
}

Szeged

2011 

Dedicated to my parents Irén and Imre and my wife Mariann 



\section{Acknowledgments}

I would like to express my thanks to the Department of Informatics at the University of Szeged for providing me with the environment and financial support for my research work.

I am heartily thankful to my great supervisor and wonderful teacher, Professor Attila Kuba, whose advice and guidance enabled me to realize this thesis.

I owe my deepest gratitude to my former colleagues Antal Nagy Ph.D. and Péter Balázs Ph.D. for their advice, proofreading, encouragement, and the great atmosphere of our productive collaborations. I am grateful to colleagues Lajos Rodek, László Ruskó, and László Nyúl Ph.D. for their co-operation in discrete tomography studies. And I would like to show my gratitude to Zoltán Kató Ph.D. for his advice, comments, and the constructive discussions we had together. Moreover, this thesis would also not have been possible without the fruitful co-operation of Márton Balaskó Ph.D. and the physical experimental data provided by him.

I cannot express my thanks enough to my wife, Marianna Imre, who has always provided me with the tranquil conditions necessary for study, who encouraged me even in difficult times, and helped me to achieve my goals.

I would also like to thank David P. Curley for checking this thesis from a linguistic point of view.

This work was supported by the NSF grant DMS 0306215 (Aspects of Discrete Tomography) and the OTKA grant T 048476 (New Aspects and Applications of Discrete Tomography in Neutron Radiography). 



\section{Abbreviations}

\begin{tabular}{|c|c|}
\hline ART & Algebraic Reconstruction Techniques \\
\hline ASCII & American Standard Code for Information Interchange \\
\hline BP & Back Projection \\
\hline DIRECT & DIscrete REConstruction Techniques \\
\hline DT & Discrete Tomography \\
\hline FBP & Filtered Back Projection \\
\hline FT & Fourier Transformation \\
\hline HTML & HyperText Markup Language \\
\hline MAP & Maximum a Posteriori \\
\hline MART & Multiplicative Algebraic Reconstruction Technique \\
\hline ML & Maximum Likelihood \\
\hline NDT & Non-destructive Testing \\
\hline NSF & National Science Foundation \\
\hline OTKA & Országos Tudományos Kutatási Alapprogramok \\
\hline PC & Personal Computer \\
\hline PGM & Portable Greymap \\
\hline RME & Relative Mean Error \\
\hline ROI & Region of Interest \\
\hline SART & Simultaneous Algebraic Reconstruction Technique \\
\hline SA & Simulated Annealing \\
\hline SIRT & Simultaneous Iterative Reconstruction Technique \\
\hline XML & Extensible Markup Language \\
\hline
\end{tabular}


XML Schema Definition

XSLT

XSL Transformations

XSL

Extensible Stylesheet Language 


\section{Contents}

Acknowledgments iii

1 Introduction $\quad 1$

2 Preliminary background 3

2.1 Classical reconstruction techniques .............. 4

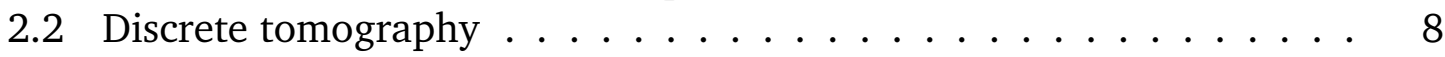

2.2 .1 Historical overview . . . . . . . . . . . . . 8

2.2.2 Fan- and parallel-beam geometry . . . . . . . . . . . 10

2.2 .3 The discretized model . . . . . . . . . . . . . . . . . . 11

2.2.4 Consistency and uniqueness . . . . . . . . . . . . . 12

2.3 The pixel-based reconstruction method . . . . . . . . . . . . . 15

2.3.1 Simulated annealing . . . . . . . . . . . . . 16

2.3.2 The reconstruction strategy . . . . . . . . . . . 17

2.4 Summary ............................. 20

3 Simulations 21

3.1 The simulation system . . . . . . . . . . . . . . . 21

3.1.1 Generation of projections . . . . . . . . . . . 21

3.1 .2 Reconstruction ................. 22

3.1.3 Evaluation and visualization . . . . . . . . . . . . 22

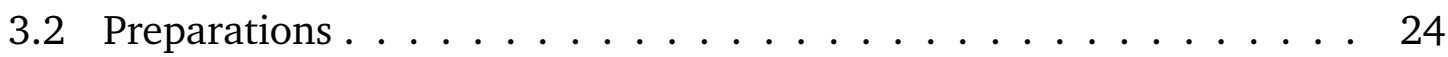

3.2.1 The test environment and protocol . . . . . . . . . . 24

3.2.2 The binary phantoms . . . . . . . . . . . . 25

3.2 .3 Initial reconstruction parameters . . . . . . . . . . 26

3.3 Simulation studies . . . . . . . . . . . . . . . . 27

3.3.1 Number of projections . . . . . . . . . . . . . . . 27

3.3.2 Geometrical properties . . . . . . . . . . . 30

3.3.3 The termination criterion ............ 31

3.3 .4 Initial temperature .................... 34

3.3 .5 Cooling factor . . . . . . . . . . . . . . . 36

3.3 .6 Effect of noise . . . . . . . . . . . . 36

3.4 Reduction of the noise effects . . . . . . . . . . . . 39

3.4 .1 Noise reduction results . . . . . . . . . . . . . . 41

3.5 Multi-level reconstruction . . . . . . . . . . . . . . . . . . 43

3.5.1 Noiseless simulation results . . . . . . . . . . . 45 
3.5.2 Noisy simulation results $\ldots \ldots \ldots \ldots \ldots$. . . . . . . 45

3.6 Summary $\ldots \ldots \ldots \ldots \ldots \ldots \ldots \ldots \ldots \ldots$

4 Physical background and pre-processing 49

4.1 Projection acquisition . . . . . . . . . . . . . . . . . . . . 49

4.2 Radiation sources . . . . . . . . . . . . . . . . . 50

4.2 .1 X-ray radiation $\ldots \ldots \ldots \ldots \ldots \ldots$

4.2 .2 Neutron radiation . . . . . . . . . . . . . . 51

4.2 .3 Gamma-ray radiation . . . . . . . . . . . . . . . . . 52

4.3 The acquired projection $\ldots \ldots \ldots \ldots \ldots \ldots \ldots$

4.4 Imaging artifacts $\ldots \ldots \ldots \ldots \ldots \ldots \ldots \ldots \ldots$

4.5 Pre-processing steps . . . . . . . . . . . . . . . . 54

4.6 Pre-processing of VIDICON tube projections . . . . . . . . . 58

4.7 Summary . . . . . . . . . . . . . . . . . 60

5 Reconstructions of physical phantoms 63

5.1 Reconstruction of a Plexiglas cylinder from X-ray projections . . . . . 64

5.1 .1 Pre-processing . . . . . . . . . . . . . . . . . 64

5.1.2 Determination of intensity levels . . . . . . . . . . 66

5.1 .3 Reconstruction results . . . . . . . . . . . . . . 67

5.2 Reconstruction of an aluminum cylinder from neutron projections . . 69

5.2 .1 Pre-processing . . . . . . . . . . . . . . 70

5.2 .2 Determination of intensity levels $\ldots \ldots \ldots \ldots$. . . . 72

5.2 .3 Reconstruction results . . . . . . . . . . . . . . 72

5.3 Reconstruction of an iron cylinder from gamma-ray projections . . . 74

5.3 .1 Pre-processing . . . . . . . . . . . . . . . . 74

5.3.2 Determination of intensity levels _ . . . . . . . . . 75

5.3 .3 Reconstruction results . . . . . . . . . . . . . . 75

5.4 Summary . . . . . . . . . . . . . . . . . 77

6 Reconstructions of physical objects 79

6.1 Reconstruction of a cardiac pacemaker battery . . . . . . . . . . 79

6.1 .1 Reconstruction results . . . . . . . . . . . . . . . . 80

6.2 Reconstruction of a boron-carbide control rod . . . . . . . . . 82

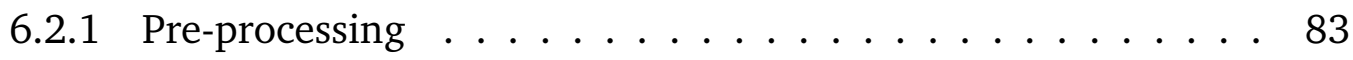

6.2 .2 Reconstruction results . . . . . . . . . . . . . . . . 84

6.3 Summary . . . . . . . . . . . . . . . . 86

7 The DIRECT framework $\quad 89$

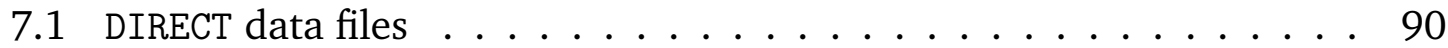

7.2 DIRECT instruction files . . . . . . . . . . . . . . . . 93

7.3 The Web interface . . . . . . . . . . . . . . . . . 93

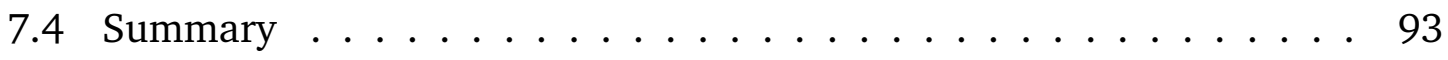

8 General summary $\quad 95$

\section{Appendices}


$\begin{array}{ll}\text { A Noisy binary reconstructions } & 97\end{array}$

B Noisy multi-level reconstructions $\quad 101$

$\begin{array}{ll}\text { C SNARK command files } & 105\end{array}$

$\begin{array}{ll}\text { Bibliography } & 107\end{array}$

$\begin{array}{ll}\text { Summary in English } & 113\end{array}$

Összefoglaló magyar nyelven 119 



\section{Chapter 1}

\section{Introduction}

In physics and image processing, a common problem is how to obtain information about the interior of an object in a non-destructive manner (non-destructive testing, NDT); that is, without damaging it in any way. For this purpose, several kinds of physical methods have been developed like X-ray, gamma-ray and neutron imaging. In industrial metallic material examinations, neutron and gamma-ray sources are generally used, while X-ray sources are often applied for non-metallic objects. The imaging tool for reconstructing objects from their projection images, obtained from some radiation source, is called tomography.

In practice, the acquisition of such projections can be a costly and time consuming procedure, so one of the main efforts is to attempt to minimize the number of projections used for the reconstruction. One way of doing this is by restricting the type of objects for reconstruction, and applying a customized tomographic method that exploits some a priori knowledge to compensate for having a reduced number of projections.

Discrete tomography (DT) is a special field of tomography where the object to be reconstructed consists of a small number of homogeneous materials/regions that can be characterized by finitely many known absorption values. It means that, using DT, only a special class of objects can be reconstructed. Accordingly, the result of a DT reconstruction is a discrete image, having values only corresponding to the known absorption coefficients. Moreover, in many cases some a priori information is also available about the object under investigation. For example, its structure is similar to a template object, or the object is made of materials that are nearly homogeneous. Since industrial objects are usually made of just a few materials, DT plays an important role in industrial NDT, where the internal configuration of a specimen needs to be determined.

For instance, if the object is made of pure iron, the number of regions is 2 (iron and air) and the reconstructed function can have only two values: the absorption coefficients of iron and air. In DT one cleverly uses the information that the function has a known discrete range. This is the main difference between the DT and classical computed tomography, as in the latter case the function/object can in general have arbitrary (non-negative) values. (A comparison with other reconstruction techniques can be found in [42].) A knowledge of discrete absorption values can allow one, using DT methods, to reconstruct objects like these from a small number 
of projections (e.g. 4-10) and/or to improve the quality of the reconstruction. A general overview on DT theory, algorithms and applications of DT can be found in $[35,37]$.

In the thesis a new DT method is presented that reconstructs objects from their parallel projections. The method treats the object being investigated as a digital image, and the reconstruction problem is handled as an optimization task that is solved by simulated annealing. After a presentation of the fundamentals of DT and the method in Chapter 2, the results obtained using the latter in phantom experiments are introduced in Chapter 3.

In order to assess the efficiency of the technique, several simulation experiments were performed. We were also interested to know how a certain reconstruction parameter (e.g. the number of projections) or the amount of noise affects the reconstructed image. These results and conclusions are presented in Section 3.2.3. Next, we introduce an extension and experiments for the DT technique in Section 3.5, which can be applied to reconstruct multi-level discrete images (i.e. their range contains more than two values) from their projections.

We also had the opportunity to test the algorithms for reconstructing real, and not necessarily binary objects. Chapter 4 introduces the physical background of the acquisition apparatus. Since the measured projection images were usually distorted by several different effects, it is common practice to apply some correction techniques before making any reconstruction from the projections. These effects are usually due to the incorrect settings of the image acquisition apparatus and the physical properties of the radiation used (e.g. non-uniform sensitivity during acquisition and on the detector plane, bright specks and the presence of statistical noise). These distorting effects and a description of the proposed pre-processing techniques are given in Section 4.5, while the benefits of using them are outlined in Section 4.6.

The reconstruction results with acquired data are given in chapters 5 and 6 . Chapter 5 discusses the reconstructions of three physical phantoms, while the latter presents two applications and shows how the new DT method can be applied when the materials constituting the object cannot be assumed to be homogeneous. That is, a reconstruction was attempted for cross-sections that are neither discrete nor continuous images, but may lie somewhere between the two.

The method was integrated into the system called DIRECT (DIscrete REConstruction Techniques) $[3,53]$. DIRECT is a programming environment available on-line. It incorporates various DT methods as well as testing and visualization tools that are being developed at the Department of Image Processing and Computer Graphics at the University of Szeged. The DIRECT framework is presented in Chapter 7. 


\section{Chapter 2}

\section{Preliminary background}

In 1917 Johann Radon presented the following transformation, which can be regarded as the fundamental theorem of parallel tomography [65]. Let us assume $s$ and $u$ denote the real variables of the Cartesian coordinate system rotated by the angle $\vartheta$, and let us assume that $f: \mathbb{R}^{2} \rightarrow \mathbb{R}$ is an integrable function in the Euclidean space. $\mathcal{R} f$ is the Radon transformation of $f$ if

$$
[\mathcal{R} f](s, \vartheta)=\int_{-\infty}^{\infty} f(s \cos \vartheta-u \sin \vartheta, s \sin \vartheta+u \cos \vartheta) d u
$$

or equivalently

$$
[\mathcal{R} f](s, \vartheta)=\int_{-\infty}^{\infty} f(x, y) \delta(x \cos \vartheta+y \sin \vartheta-s) d x d y,
$$

where $\delta(x)$ is the Dirac delta function. The Radon transformation data is often called a sinogram because the Radon transformation of a Dirac delta function is a distribution supported on the graph of a sine wave. Furthermore, $[\mathcal{R} f](s, \tilde{\vartheta})$ for a fixed angle $\tilde{\vartheta}$ is the $\tilde{\vartheta}$ angle parallel projection of $f$ or $\tilde{\vartheta}$ projection of $f$ (see Figure 2.1).

Mathematically, there is an interesting inverse problem of how to find the function $f$ for a given $\mathcal{R} f$ that satisfies the inverse transformation

$$
f(x, y)=\int_{0}^{\pi}[\mathcal{R} f](x \cos \vartheta+y \sin \vartheta, \vartheta) d \vartheta
$$

of Eq. 2.1. This theoretical way of inversion usually requires infinitely many projections, whose condition does not hold after discretization, and $\mathcal{R}$ can no longer be considered injective. Other problems arise when $\mathcal{R}^{-1}$ is applied to the perturbed version of $[\mathcal{R} f](s, \vartheta)$. Therefore, the inverse problem has to be rephrased as follows.

Given $g_{f}: \mathbb{R}^{2} \rightarrow \mathbb{R}, g_{f}=\mathcal{R} f$, the Radon transformation of an unknown $f: \mathbb{R}^{2} \rightarrow$ $\mathbb{R}$ function. The Tomographic Reconstruction Problem is to find a function $\tilde{f}$ (not necessarily equal to $f$ ) that fulfills the equation $\tilde{f}=\mathcal{R}^{-1} g_{f}$. In other words, the goal is to find a function $\tilde{f}$ such that its projections are equal to some given function 


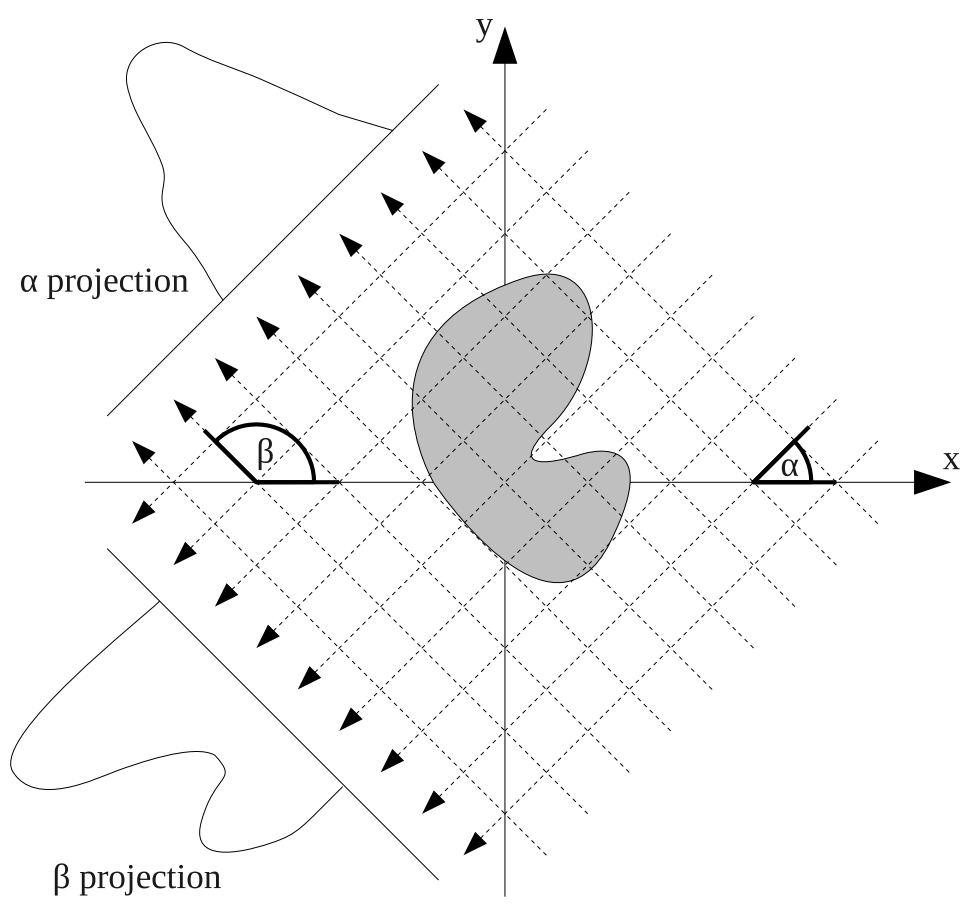

Figure 2.1: A homogeneous object (grey area) and its two continuous parallel projections taken at angles $\alpha$ and $\beta$.

$g(s, \vartheta)$. The technique used to calculate $\tilde{f}$ is called the tomographic reconstruction, and the functions $f$ and $\tilde{f}$ are sometimes called the original and reconstructed image functions or simply images.

\subsection{Classical reconstruction techniques}

Although several different classifications of tomographic techniques can be given, over the past few decades three widely accepted families of reconstruction methods have emerged in tomography. They approach the problem from different mathematical aspects and try to tackle it with the suboptimal conditions arising in real applications. They are the following:

\section{The direct analytical approach}

Back Projection (BP) is the most obvious analytic reconstruction technique deduced directly from Eq. 2.1. BP and its discrete form can be viewed as the inverse Radon transformation, where the line integrals are smeared back onto the Euclidean plane at the respective angles, in accordance with Eq. 2.3.

Since, in practice, BP performs well only under ideal circumstances (e.g. no distortion in the acquired projections and an unlimited number of projections are available), Filtered Back Projection (FBP), an extended variant of the direct inverse 
method is commonly used. FBP is based on the result of the Fourier slice theorem [39], which says that the 1-dimensional Fourier transformation (FT) of a parallel projection taken at angle $\tilde{\vartheta}$ equals the central radial slice at angle $\tilde{\vartheta}$ in the 2-dimensional FT of the original object. This statement allows one to apply frequency filters on the projection data in the frequency domain. Accordingly, the FBP technique involves the following steps:

- Fourier transformation of the 1-dimensional projections.

- Multiplication by a suitable frequency domain filter.

- Taking the inverse FT.

- Back projection of filtered projection profiles.

One may ask why it is necessary to transform the projection data into the frequency domain, when we know that a convolution in the spatial domain gives the same results as a pointwise multiplication in the frequency domain (see convolution theorem in [18]). The answer is more practical than theoretical. The transformations between spatial and frequency domains plus the pointwise operations in frequency space usually require less computation than a convolution in the spatial domain.

$\mathrm{BP} / \mathrm{FBP}$ has several advantages. For instance, it is the fastest tomographic reconstruction technique, it is easy to understand, and not hard to implement. However, it is quite sensitive to distorting effects (e.g. a big amount of noise) that cannot be eliminated by frequency filters. These artifacts usually appear as strong streaks in the reconstruction, degrading the quality of the resultant image.

\section{The algebraic approach}

The Algebraic Reconstruction Technique (ART), first proposed by Gordon et al. in [32] and Herman in [33], is an iterative reconstruction method. It treats the reconstruction problem as the solution of a linear system of equations (Figure 2.2) given below.

Let $f_{i}$ denote the value belonging to the $i$ th picture element in the image $f$, and let $N$ be the total number of cells in $f$. Let us define

$$
p_{i}=\sum_{j=1}^{N} w_{i, j} f_{j},
$$

where $i=1,2, \ldots, M$ ( $M$ is the number of lines in all the projections) and $w_{i, j}$ is the weighting factor that represents the contribution of the $j$ th element to the $i$ th line integral. It yields the equation system defined in Eq. 2.5. 


$$
\begin{gathered}
w_{1,1} f_{1}+w_{1,2} f_{2}+\cdots+w_{1, N} f_{N}=p_{1} \\
w_{2,1} f_{1}+w_{2,2} f_{2}+\cdots+w_{2, N} f_{N}=p_{2} \\
\vdots \\
w_{M, 1} f_{1}+w_{M, 2} f_{2}+\cdots+w_{M, N} f_{N}=p_{M}
\end{gathered}
$$

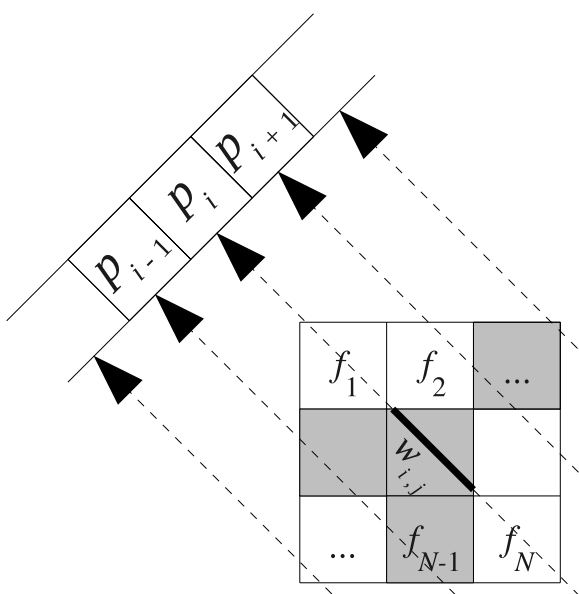

Figure 2.2: Scheme of the algebraic reconstruction technique.

Each equation here determines a hyperplane in the $N$-dimensional space. When a unique solution exists, all the hyperplanes intersect at a single point and provide the solution. In order to find this point a recast of the iterative Kaczmarz method [38] was suggested in [32]. That is, the solution is iteratively converged with the sequence of $f^{(0)}, f^{(1)}, \ldots$ images, where

$$
f^{(i)}=f^{(i-1)}+\frac{p_{i}-q_{i}}{\sum_{k=1}^{N} w_{i, k}^{2}} w_{i, j}
$$

and

$$
q_{i}=\sum_{k=1}^{N} w_{i, k} f_{k}^{(i-1)}
$$

assuming an initial guess of $f^{(0)}$ and $i \geq 1$. In other words, for each iteration the difference between $p_{i}$ and $q_{i}$ is distributed between the pixels hit by the $i$ th projection line, where the distribution is proportional to the length of intercepted line segments. In this manner, the method projects the $f^{(i-1)}$ point onto the hyperplane represented by the $i$ th equation in Eq. 2.5. 
ART gives acceptable reconstructions even when only a limited number of projections are available, but it produces results of worse quality when the projections are corrupted by statistical noise. This can be moderated by applying a smoothing operator during the reconstruction, but this removes the image details as well.

A number of algebraic reconstruction techniques have evolved besides ART, such as Simultaneous Iterative Reconstruction Technique (SIRT) [30], the ART variant Multiplicative Algebraic Reconstruction Technique (MART) [32], and Simultaneous Algebraic Reconstruction Technique (SART)[10]. The latter combines the best aspects of ART and SIRT.

\section{The probabilistic approach}

ART and FBP do not give satisfactory results if the reconstruction is performed using just a few noisy projections. So is there a mathematical method that solves this problem and provides acceptable results under such circumstances? In general, the answer to this question is no. However, if the original reconstruction problem is approached in a different way, there is some hope. One possible answer to the challenge of image reconstruction from noisy projections is hidden in standard probability theory.

Maximum likelihood (ML) [22] and maximum a posteriori (MAP)-based image reconstruction methods have their roots in Bayesian probability theory. According to Bayes' theorem, the posterior distribution of an image $f$ given a $P$ set of projections can be calculated via the formula

$$
\mathcal{P}(f \mid P)=\frac{\Pi(f) L(P \mid f)}{\mathcal{P}(P)},
$$

where $\Pi(f)$ denotes the a priori knowledge on $f, \mathcal{P}(P)$ is the probability of projections $P$, and $L(P \mid f)$ is the likelihood function having the probability of $P$ given the image $f$. The task is to find the location $f^{\star}$, where Eq. 2.8 is maximal. Since $\mathcal{P}(P)$ is constant for a fixed set of projections and independent of $f$, the optimization problem can be formulated as

$$
\max _{f} \Pi(f) L(P \mid f),
$$

upon which the essence of the MAP technique is based.

The a priori information contained in $\Pi(f)$ usually expresses the expectations against the reconstruction result like smoothness, big contiguous regions, minimal total length of edges, or other local properties. Geman and Geman [29] and Matej et al. [60] extensively discuss how such information can be incorporated into $\Pi(f)$ using the Gibbs distribution. $L(P \mid f)$ establishes the connection between the $P$ set of projections and the candidate image $f$; in addition, it includes a noise model. In [21], Chan et al. apply the Gaussian prior of the $\sigma$ standard deviation

$$
L(P \mid f)=\frac{1}{{\sqrt{2 \pi \sigma^{2}}}^{N}} e^{-\sum_{i=1}^{N} \frac{\left(p_{i}-r_{i}\right)^{2}}{2 \sigma^{2}}},
$$

whereas Frese et al. [25] suggest the Poisson noise model 


$$
L(P \mid f)=\prod_{i=1}^{N} L\left(p_{i} \mid r_{i}\right)=\prod_{i=1}^{N} e^{-r_{i}} \frac{r_{i}^{p_{i}}}{p_{i} !},
$$

assuming that $p_{i}$ denote the $i$ th measurement in $P$, and $r_{i}$ is the $i$ th measurement in the $R$ set of projections of $f$. Here, $p_{i}$ (or $r_{i}$ ) is defined according to Eq. 2.4.

The expression in Eq. 2.9 can be computed in numerous ways:

- Analytically, if the posterior probability can be expressed in a closed form.

- By employing the expectation-maximization algorithm.

- By choosing a numerical optimization method.

- Via a stochastic optimizer like a Monte Carlo method.

As Eq. 2.9 rarely has a simple form, the stochastic optimization procedure is often unavoidable. In practice, Monte Carlo or Gibbs samplers [60] are normally used to find the optimal solution.

Fisher's model fitting ML method [24] is closely related to MAP, but it utilizes a reduced optimization objective that omits the a priori distribution. Due to the lack of a priori information, ML apparently underperforms MAP, which is demonstrated in [21] quantitatively. Generally speaking, MAP can be easily adapted to the needs of DT, which gives a technique that is robust against additive Gaussian noise.

\subsection{Discrete tomography}

Historically, discrete tomography was born when researchers sought to address the following problem. Let us consider the domain of an unknown discrete function $f$ as a finite set of ordered pairs of integers. Let us suppose that the range of $f$ is a known finite discrete set, and then assume that the row and column sums of $f$ are also known. The task is to find a method that reconstructs $f$. For example, the row sums of a $13 \times 13$ discrete image are depicted in Figure 2.3.

The name discrete tomography, as a branch of tomography dealing with such problems, was introduced by Larry Shepp, who organized the first meeting on this topic in 1994. Here the author will introduce and discuss a new DT method that is capable of performing reconstructions using a set of (at least two) weighted sums.

\subsubsection{Historical overview}

Since 1994 several interesting mathematical problems in this field have been raised and solved, and numerous others are still waiting to be studied. Since then this branch of computer science has evolved into a separate field, whose mathematical tools and methods are independent of its tomography ancestor. The theory of DT is based on discrete mathematics, but it has connections with combinatorics and function analysis as well. 


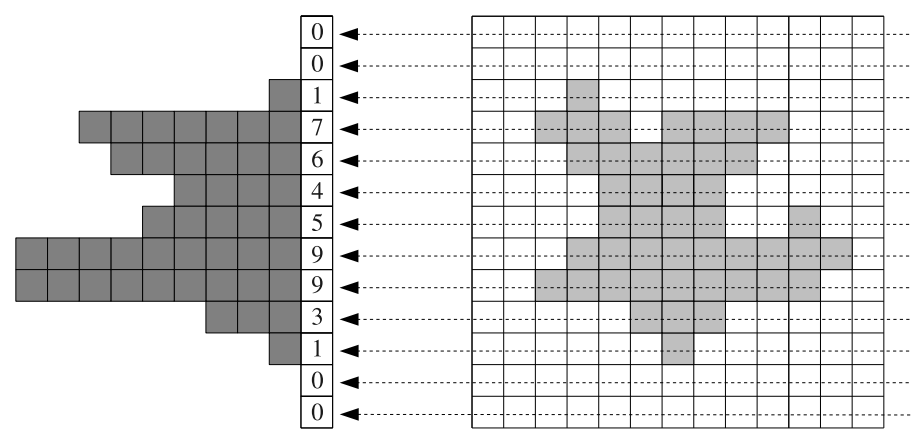

Figure 2.3: A homogeneous object (denoted by light grey rectangles) and its row sums. The sums are calculated by summing the number of light grey rectangles along the projection lines. The dark grey rectangles depict the projection presented as a bar diagram.

Its foundation and first results date back to 1949 [59], when a necessary and sufficient condition was given by Lorentz to decide if a function-pair are the projections of a 2-dimensional measurable set. Lorentz also proved that there always exist two different bounded sets that have the same $k$ projections for any integer $k$. Then in the 1950s Ryser [67] provided another necessary and sufficient condition for a pair of integral vectors being the row and column sums of a special kind of measurable set, namely the binary $(0,1)$-matrix, and much later Kaneko and Huang discussed the relation between discrete and continuous cases in [40].

The authors of [28] and [26] focused on the geometric aspects of tomography like the reconstruction of planar convex bodies in the continuous and discrete cases. They pointed out that all such bodies can be reconstructed using four suitable projections. This theorem had a very important impact on DT reconstruction problems as well. It was shown that an arbitrary discrete set, in general, cannot be reconstructed from a finite number of projections. However, if the number of points in the discrete set is known, a unique solution can be produced from the finitely many projections. Actually, there are three cornerstone problems in DT, namely consistency, uniqueness and image reconstruction. These will be discussed later on.

In the past few years a number of theoretical DT methods were elaborated. Each of them approaches the reconstruction problem in different ways. Matej, Vardi, Herman, and Vardi [60] suggested representing the image function $f$ by a hexagonal grid, which is assumed to have a Gibbs distribution with known local properties, as described in [29]. Other reconstruction methods are based on Bayesian probability principles, and apply maximum a posteriori expectation maximization $[34,58]$ or maximum likelihood [68] techniques. Kuba, Nagy and Balogh were interested in the reconstruction of hv-convex binary patterns and published reconstruction algorithms [46, 48-50] using two orthogonal projections. Adaptations of ART and its variants are also applicable for DT reconstruction, and provide promising results even when there are few projections available. A detailed summary of the theory, algorithms, and applications of DT is given in [35]. 


\subsubsection{Fan- and parallel-beam geometry}

Two types of projection systems are commonly employed in tomography. The difference lies in the arrangement of the projection lines and the number of their origin. As these arrangements originate from radiography, their terminology is often used in tomography as well. Accordingly, the projection lines are usually called radiation beams or projection beams. The origin of a radiation beam is knwon as the radiation source, which is the origin of projections lines in tomography. Next, the device that measures the radiation passing through the object being investigated (giving line integrals after some transformation) is called the detector bin, or detector for short.

In the fan-beam projection system the projection lines originate from a pointwise source and diverge radially. A typical layout for this can be seen in Figure 2.4, where the beams are set up equiangularly in the same plane, and the line integrals are measured by the detectors. This arrangement is widely used in practice, such as in medical examinations.

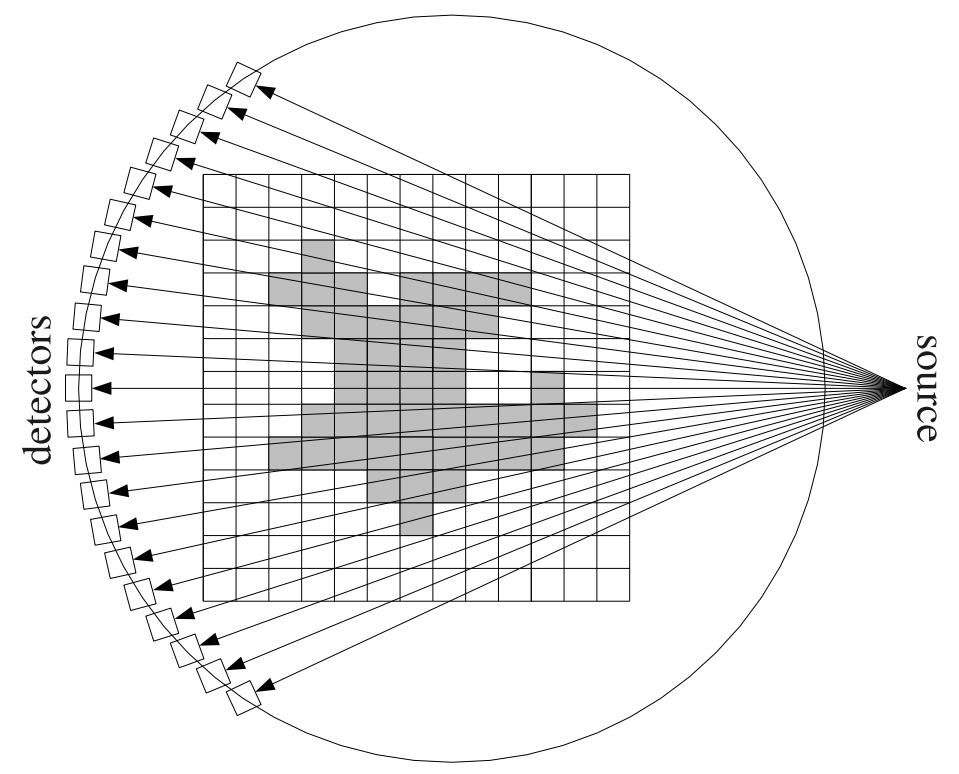

Figure 2.4: Scheme of a fan-beam projection system.

The other family of projection systems is the parallel-beam configuration, where each projection line has its own source. They are parallel and have the same direction. This solution is depicted in Figure 2.5. It is realizable only if the source of the beams in a fan-beam arrangement is located infinitely far from the object to be projected; then the system yields the same integral measurements as the parallel-beam set-up. A parallel-beam scheme describes the imaging system of research reactors well, where usually just a narrow radiation beam is produced.

Here we assume that every projection is produced by a parallel-beam projection system. For research results and reconstruction experiments concerning the fanbeam system, see Nagy and Kuba's article [62]. 


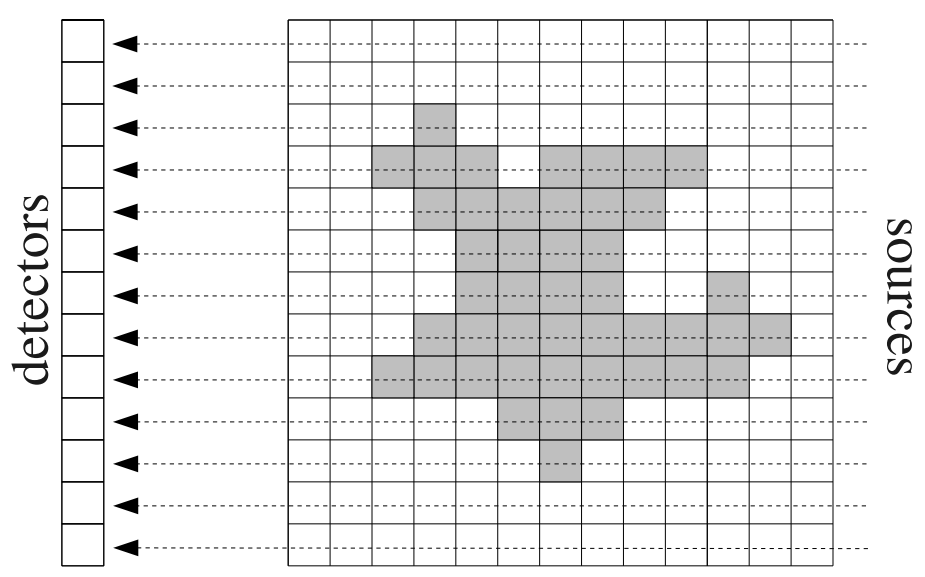

Figure 2.5: Scheme of a parallel-beam projection system.

\subsubsection{The discretized model}

With continuous functions, the parallel-beam Radon transformation is applied using Eq. 2.1. However, in the case of discrete spaces it is necessary to turn the model into a discrete form. Hence we will consider $f$ as a discrete function over a regular lattice set $W$ having the size $h \times h(h \in \mathbb{Z}, h \geq 1)$, where each element takes a value from $D=\left\{k_{1}, \ldots, k_{n}\right\},\left(k_{i} \in[0,1], 1 \leq i \leq n, n \geq 2\right)$. It is seen that the simplest situation is when $n=2$; that is, the range of $f$ consists of two values only. In this special case $f$ is called the binary digital image, or binary image for short.

Let us define

$$
[\mathcal{R} f](s, \vartheta)=\sum_{(i, j) \in W} w_{i, j, s, \vartheta} f(i, j)
$$

where $i, j \in \mathbb{Z}^{0,+}$, and $w_{i, j, s, \vartheta}$ is a non-negative real number. $w_{i, j, s, \vartheta}$ is non-zero if and only if the projection line $(s, \vartheta)$ crosses the lattice element $(i, j)$ in $f$, and expresses the length of the line segment intercepted by the edges of $(i, j)$, as depicted in Figure 2.6. Other measures can also be applied instead of using line integrals. For instance, Nagy calculates 'strip' (area) integrals in [63]. Here the author will only use line integrals, and not other approaches that are just as valid.

In addition, let

$$
w_{s, \vartheta}=\sum_{(i, j) \in W} w_{i, j, s, \vartheta},
$$

which can be interpreted as the length of the intersection of $W$ and the projection line $(s, \vartheta)$. Consequently, the values of $[\mathcal{R} f](s, \vartheta)$ can be regarded as weighted sums of values in $f$ intersected by the corresponding projection lines. Recall that $[\mathcal{R} f](s, \vartheta)$ is called the sinogram of $f$, which can be discretized and represented as a 2-dimensional matrix and visualized as a grey-level map. The sinogram in 


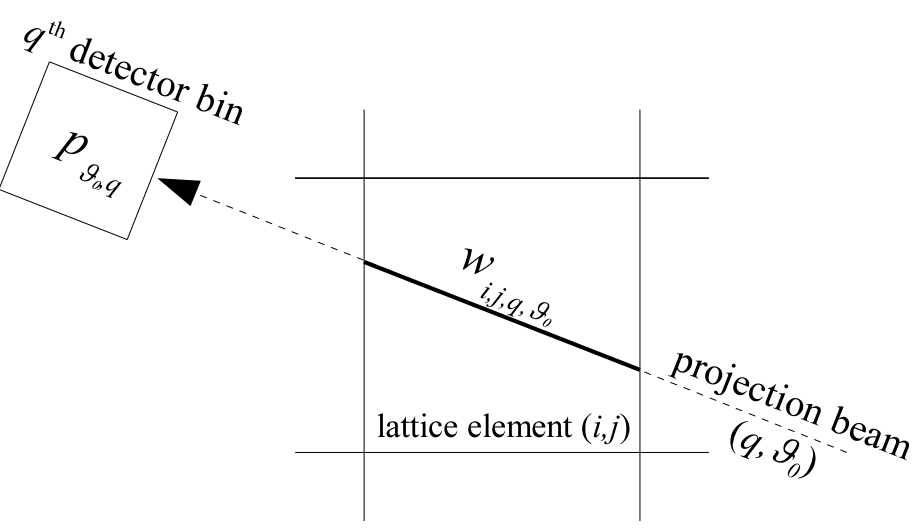

Figure 2.6: Interception of the projection beam $\left(q, \vartheta_{0}\right)$ and lattice element $(i, j)$.

Figure 2.7(c) contains 180 projections, while Figure 2.7(d) contains only one tenth of them. The grey-level values represent the sums calculated along the projections lines, where a brighter pixel means a greater sum. If a sinogram is treated as a 2-dimensional function, $s$ and $\vartheta$ lie on the horizontal and vertical axes, respectively.

For a fixed angle $\vartheta_{0} \in \mathbb{R}$ the 1-dimensional vector $[\mathcal{R} f]\left(s, \vartheta_{0}\right)$ is called the $\vartheta_{0}$ projection of $f$. For the sake of brevity, it will be denoted by $P_{\vartheta_{0}}^{f}$ or $P_{\vartheta_{0}}$ if $f$ is unambiguous. A $\vartheta_{0}$ projection of $f$ is a 1-dimensional (column) vector

$$
P_{\vartheta_{0}}^{f}=[\mathcal{R} f]\left(\vartheta_{0}\right)=\left(p_{\vartheta_{0}, 1}^{f}, p_{\vartheta_{0}, 2}^{f}, \ldots, p_{\vartheta_{0}, d}^{f}\right)^{T},
$$

where $d \in \mathbb{Z}^{+}, d \geq 1$, and

$$
p_{\vartheta_{0}, q}^{f}=\sum_{(i, j) \in W} w_{i, j, q, \vartheta_{0}} f(i, j)
$$

is the line integral measured by the $q$ th detector bin, as shown in Figure 2.6. The superscript $f$ may be dropped when there is no ambiguity.

The definitions above imply that each column (or row if rotated) of a sinogram is a projection vector. Such a vector, actually the $270^{\circ}$ projection of the image in Figure 2.7(a), is shown as a bar diagram in Figure 2.7(b).

\subsubsection{Consistency and uniqueness}

After the image reconstruction problem, consistency and uniqueness are the most important issues of DT. Their exact definitions are not provided here, but can be found in [47]. These issues can be summarized by asking the following questions.

- Consistency problem. Given a $\left\{P_{\vartheta_{1}}, \ldots, P_{\vartheta_{m}}\right\}$ set of projections, does there exist a discrete image $f$, where $P_{\vartheta_{i}}=[\mathcal{R} f]\left(s, \vartheta_{i}\right), i=1, \ldots, m$ ? In other words, does there exist an image $f$ that satisfies the given projections? 


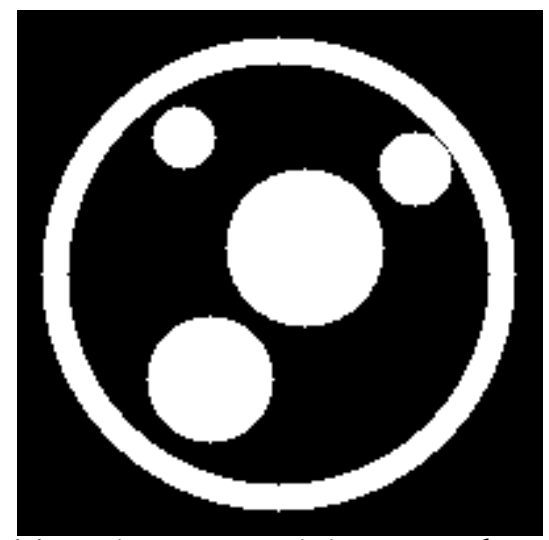

(a) An image containing two values: 0 (black), and 1 (white).

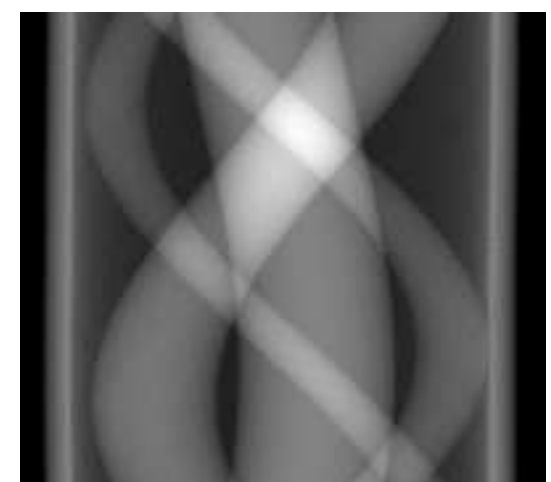

(c) A sinogram of (a) containing 180 projection vectors represented as a grey-level map.

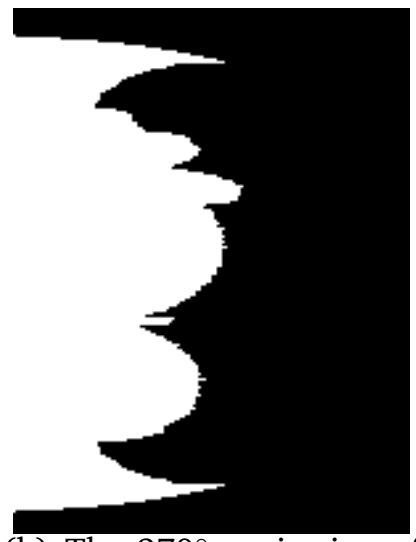

(b) The $270^{\circ}$ projection of (a) represented as a bar diagram

(d) A sinogram of (a) containing

18 projection vectors represented as a grey-level map. Horizontal axis: number of measurements. Vertical axis: projection angle. Each row may be regarded as a projection vector represented as a grey-level map.

Figure 2.7: A projection vector and two sinograms of a binary image.

It is trivial to see that one can construct a sinogram $\tilde{g}=\left[\tilde{P}_{\vartheta_{1}} \ldots \tilde{P}_{\vartheta_{m}}\right]$, where an image $f$ such that $f=\mathcal{R}^{-1} \tilde{g}$ does not exist. In this case $\tilde{g}$ is said to be inconsistent, while $\tilde{g}$ is considered consistent otherwise. Examples of inconsistent projections are shown in Figure 2.8.

Clearly, a necessary condition of consistency is that $\sum_{l=1}^{d} p_{\vartheta_{i}, l}=\sum_{l=1}^{d} p_{\vartheta_{j}, l}$ holds for all $\vartheta_{i}$ and $\vartheta_{j}$ projections; otherwise no suitable image can be constructed for the given sums. As this condition is commonly violated by the physical measurements, the reconstruction techniques used in practice have to take the inconsistency case into account.

- Uniqueness problem. Given an image $f$ and a set $P=\left\{P_{\vartheta_{0}}, \ldots, P_{\vartheta_{m}}\right\}$ of its (consistent) projections, do there exist other images that satisfy $P$, but are different from $f$ ?

In general, a number of images may satisfy a fixed set of consistent projections. If a reconstruction has already been calculated, other images can be constructed by applying switching components. When considering the image $f$ 


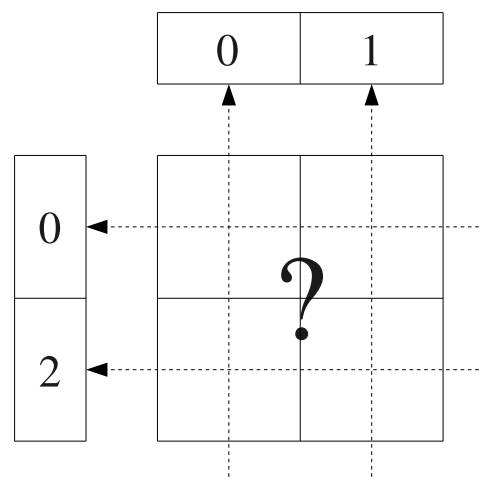

Figure 2.8: Two inconsistent natural (a column and a row) projection vectors.

and the set of its projections, applying a switching component means changing $f$ without resulting in any changes in $P$. Switching components are dependent on the number of intensity levels, number of projections, and their directions, but independent of other properties of the image. For example, a switching component pair for binary images and two natural (a column and a row) projection vectors are shown in Figure 2.9. This topic is discussed at length in [35].

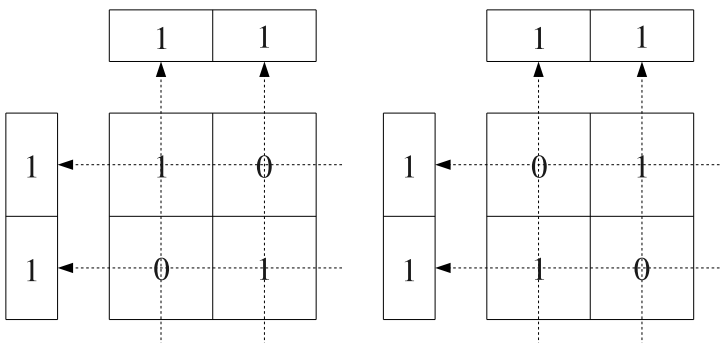

Figure 2.9: A switching component pair for binary images with column and row projection vectors.

Reconstruction techniques usually provide only one resultant image, but do not produce every possible image that fits the given projections. However, by using switching components other solutions can also be constructed. Nevertheless, the question arises of how the image from which the projections were taken can be chosen from the variety of possible solutions. For this purpose, some additional properties known about the image to be reconstructed need to be incorporated into the image reconstruction model. In the next section, a stochastic technique will be introduced that can handle inconsistency problems and apply a priori expectations for selecting the desired image reconstruction from the number of possible solutions.

The definitions and a detailed discussion of consistency, uniqueness and complexity can be found in $[27,44,47]$. 


\subsection{The pixel-based reconstruction method}

Here an alternative method is presented that treats the image reconstruction problem in a different way from ART, FBP and MAP. While classical methods give good reconstruction results when there are a lot of projections available, the method described here can produce good results even with 10 or fewer projections. In order to compensate for the loss of information caused by reducing the number of projections, this method needs to know the range (intensity levels) of the image function to be reconstructed. Recall that it is a basic condition of DT. Besides the range, other additional a priori information is also often included for a successful reconstruction. This information may be the number of homogeneous regions appearing in the image to be reconstructed, the size of the image or some geometric information about the objects contained in the image (e.g. a prototype function [63] or a parametric description [42]).

The new pixel-based method (published by the author in [17, 42]) essentially turns the reconstruction problem into an optimization task, and minimizes the objective functional

$$
\Phi(f)=\sum_{\vartheta}\left\|[\mathcal{R} f](\vartheta)-P_{\vartheta}\right\|^{2}+\gamma \phi(f),
$$

where $P_{\vartheta}$ denotes the $\vartheta$ projection, $f$ is the 2-dimensional image function that approximates the solution, $[\mathcal{R} f](\vartheta)$ denotes the projection of image $f$ calculated at the angle $\vartheta,\|$.$\| is the Euclidean norm, \phi(f)$ is the so-called regularization (or penalty) term, and $\gamma \geq 0$ is the regularization parameter.

In Eq. 2.16 the first term is a functional, which represents the distance between the projections of $f$ and the given projection data $P_{\vartheta}$. This term tells us how well the projections of $f$ approximate the given projections.

As mentioned above, the fewer the number of projections used, the more a priori information should be exploited. Some pieces of information can be incorporated into the regularization term, which helps one choose the right solution from the number of possible reconstructions. (The existence of more than one solution can be accounted for by the phenomenon of switching components, as described in Section 2.2.4.) For example, if the regularization term contains the so-called prototype image, it has the form

$$
\phi(f)=\left\|f-f_{0}\right\|^{2},
$$

where $f_{0}$ is the prototype function or object. $f_{0}$ is an image function like $f$ that has the same domain and range, and is similar to the expected reconstruction result. Evidently, Eq. 2.17 describes the difference between $f$ and a given prototype object $f_{0}$. For instance, if $f_{0}$ is a non-zero image, the penalty term prefers images being similar to $f_{0}$. Should $f_{0}$ be the zero image, solutions are sought that have a small norm. Several studies have been published that employ this regularization approach. For more details, see [63].

Next, the positive regularization parameter $\gamma$ is used to control the relative importance of the first and second terms. If $\gamma$ is big, the reconstruction procedure 
should return a solution that fits the a priori information, but it is less suitable for the given projection data. It is not hard to see that different values of $\gamma$ need to be adjusted for different reconstruction goals. As usual for energy minimization methods, there exists no general rule on the selection of regularization parameters, so $\gamma$ has to be suitably chosen based on specific requirements.

The formulation in Eq. 2.16 clearly reveals the difference between the pixelbased method and MAP. While MAP uses the Bayesian probabilistic model presented in Section 2.1, the pixel-based method employs a general functional and does not require probabilistic tools.

A key question is, of course, what optimization method should be chosen for the minimization of $\Phi(f)$ defined in Eq. 2.16. Since we usually have no information about the properties of the objective functional, and there is no technique available that tells us how to find a good initial point that is close to a global minimum, the method used must be chosen from the family of discrete global optimizers like the greedy randomized adaptive search procedure (GRASP) [23], genetic algorithms [31] or simulated annealing [41, 61]. Here the author opted for simulated annealing.

\subsubsection{Simulated annealing}

Simulated annealing (SA) $[61,70]$ is a procedure that originates from models which describe the annealing process in metallurgy. The procedure is applied in order to let the material reach a defect-free crystal state via heating and controlled annealing. Heating causes the atoms to wander from their initial positions, whereas a slow annealing provides the possibility of finding a new position of a lower energy than the initial one.

From an optimization point of view, SA is a statistical iterative technique and it performs well for arbitrary discrete functions. Firstly, SA was a reasonable choice because it did not require the variation of the objective functional in Eq. 2.16, whose calculation would have been rather complicated to perform. Secondly, heuristic optimizers were soon excluded, as the search space was quite big, and it was difficult to define the neighbourhood of a heuristic step.

It is also widely known for SA that finding a global minimum of an arbitrary discrete function has a probability of 1 , but this statement is only true if infinitely many iteration steps are performed. It may sound intractable, but these days computers are fast enough to speedily execute a sufficient number of iterations.

SA has already been successfully applied to other fields of image processing like the segmentation of images [29]. This should really come as no surprise, because there is a close connection between DT and segmentation. If the result of a DT technique is regarded as a globally labelled image, where each contiguous region of the same intensity belongs to the same segment, a segmentation of $f$ immediately follows. However, while the image segmentation is based on $f$, a DT reconstruction is carried out using $\mathcal{R} f$. 


\subsubsection{The reconstruction strategy}

The reconstruction method was mainly based on the article [66], and was developed in the way shown by the flow chart in Figure 2.10, which can be described as follows.

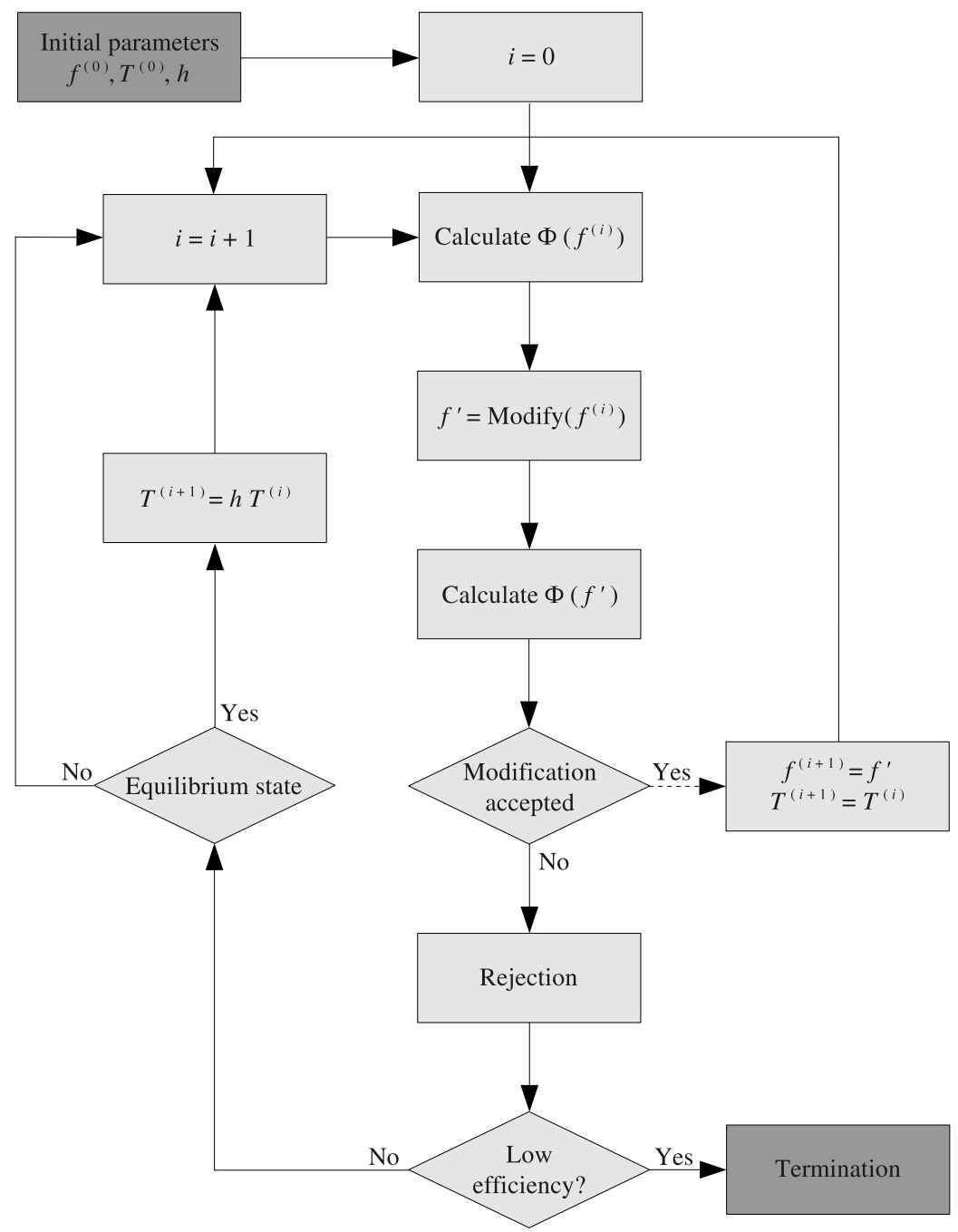

Figure 2.10: Flow chart for the homogeneous SA method.

\section{Iterative core}

A reconstruction result is obtained via a sequence of approximating image functions $f^{(0)}, f^{(1)}, \ldots$ such that $\left|\Phi\left(f^{(i)}\right)-\Phi\left(f^{\star}\right)\right| \rightarrow 0$ when $i \rightarrow \infty$, where $f^{(i)}$ denotes the image function in the $i$ th iteration, $i \in \mathbb{Z}^{0,+}$, and $f^{\star}$ is a minimum locus of $\Phi$. For each iteration step, the $(i+1)$ th image function is constructed by perturbing the $i$ th image according to a predefined modification rule. 


\section{Perturbation of $f^{(i)}$}

The simplest example for the modification process is when the range of the function $f^{(i)}$ consists of two values only, such as 0 and 1 . The rule for changing the binary image function $f^{(i)}$ is quite simple. Let us randomly choose a pixel of $f^{(i)}$, and switch its ( 0 or 1$)$ intensity to the other intensity value. In this way we get the new image $f^{\prime}$, differing from $f^{(i)}$ by one pixel only.

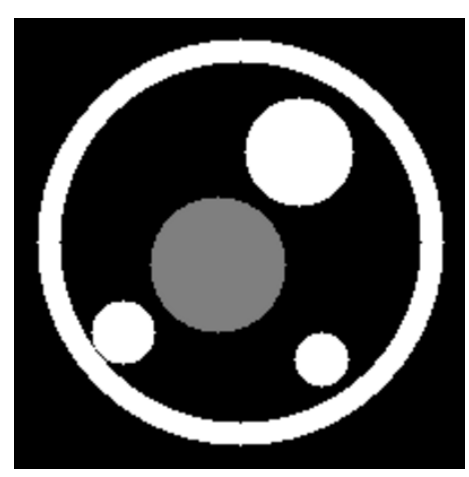

Figure 2.11: A 3-level discrete image.

When $f^{(i)}$ contains more than two values, $f^{(i)}$ is a so-called multi-level image function (see Figure 2.11). A multi-level image takes its values from a known $D=$ $\left\{k_{1}, k_{2}, \ldots, k_{n}\right\}$ discrete set of intensity values, where $n(\geq 3)$ is an integer, namely the cardinality of the range of $f^{(i)}$. Hence the modification rule also differs from the one used for binary images. If $f^{(i)}$ has the value $k_{j}(1 \leq j \leq n)$ at the randomly selected position, then set its new value to $k_{l}$ in $f^{\prime}$, where $l$ is randomly picked from the discrete set $\{1, \ldots, n\}$. An alternative modification strategy might be when $k_{l}$ is calculated according to the following formula:

$$
k_{l}=\left\{\begin{array}{ll}
k_{j-1}, & \text { if } 2 \leq j \leq n-1 \text { and } \xi<0.5 \\
k_{j+1}, & \text { if } 2 \leq j \leq n-1 \text { and } \xi \geq 0.5 \\
k_{j-1}, & \text { if } j=n \\
k_{j+1}, & \text { if } j=1
\end{array},\right.
$$

where $\xi$ is a probability variable of the uniform distribution taking its value from $[0,1)$.

\section{Acceptance criterion}

An $f^{\prime}$ perturbation of $f^{(i)}$ is accepted if $\Phi\left(f^{\prime}\right) \leq \Phi\left(f^{(i)}\right)$ (dashed arrow in Figure 2.10). After, let $f^{(i+1)}=f^{\prime}$; that is, the optimization procedure carries on with the newly created $f^{\prime}$ image in the next iteration. Otherwise, if $\Phi\left(f^{\prime}\right)>\Phi\left(f^{(i)}\right), f^{\prime}$ can still be accepted with a certain probability depending on $\Delta \Phi=\Phi\left(f^{\prime}\right)-\Phi\left(f^{(i)}\right)$, the current temperature, and a randomly generated $z$ value of the uniform distribution from the interval $(0,1)$, allowing the optimizer to escape from local minima. 
The acceptance condition for bad configurations is given by the Metropolis criterion, namely

$$
e^{-\Delta \Phi / \kappa T^{(i)}}>z
$$

where $\kappa$ is the Boltzmann constant $\left(11.3805 \times 10^{-23} \mathrm{~m}^{2} \mathrm{~kg} \mathrm{~s}^{-2} \mathrm{~K}^{-1}\right)$ and $T^{(i)}$ is the temperature in the current iteration. The denominator in the exponent is the product of $\kappa$ and $T^{(i)}$, reflecting the fact that the individual values here are irrelevant from an algorithm point of view. It allows us to fix $\kappa=1$, instead of using the original miniscule value of the Boltzmann constant, thus avoiding the need for having extremely high temperatures to get reasonable $\kappa T^{(i)}$ products.

\section{Temperature scheduling}

$T^{(i)}$ decreases during the iterations according to a suitable schedule, but as seen in the flow chart, the temperature is not reduced for each iteration. It is only reduced in the case where the optimizer attains an equilibrium state at the current temperature level. By equilibrium, we mean that the optimizer is unable to reduce the objective values any further due to the many accepted bad configurations at a given $T^{(i)}$ level. This variant of SA is called homogeneous simulated annealing.

A pitfall of the technique is how 'equilibrium' should be defined mathematically. For this purpose, an easily computable indicator was chosen, which is based on the variance of the last $\Phi$ s. Formally, the method attains equilibrium when

$$
\sigma_{1}^{2}<\sigma_{0}^{2}
$$

where $\sigma_{t}^{2}$ is the variance calculated from $\Phi_{i-t v}, \Phi_{i-t v-1}, \ldots, \Phi_{i-(t+1) v+1}, \Phi_{i}=\Phi\left(f^{(i)}\right)$, and $v$ denotes the sample size the variance is calculated from. That is, a session terminates at a given temperature level if the variance of $\Phi$ s is greater in the last $v$ than in the preceding $v$ iterations.

Another interesting question is how the temperature should be reduced every time the equilibrium state is attained. For this,

$$
T^{(i+1)}=T^{(i)} \cdot h
$$

is generally used, where $h$ is called the cooling factor, taking its value from the interval $(0,1)$. In other words, $T^{(i)}$ is decreased by $(1-h) \cdot 100 \%$ each time $T^{(i)}$ is reduced.

For the sake of completeness, the inhomogeneous form of SA lowers the temperature for each iteration. Experience tells us that this sort of SA terminates faster, but it usually gives worse results than the homogeneous scheduling process. Hence the optimizer developed applies the above-mentioned homogeneous annealing schedule.

\section{Termination condition}

Since the optimization process could run endlessly, a termination criterion has to be included in the algorithm. The most obvious termination condition is when 
some $f$ configuration is found where the first term of $\Phi(f)$ attains 0 . However, especially under noisy circumstances, the projections are usually inconsistent, and no such $f$ satisfying the projections exists (see Section 2.2.4). Such situations have been extensively analyzed in [21]. A better solution is to compute an efficiency measure, which indicates that no further improvements can be perceived in the recent objective values. It is defined by the ratio

$$
\frac{N_{r e j}}{N_{a t t}} .
$$

Here $N_{\text {rej }}$ denotes the number of rejected configurations in the last $N_{\text {att }}$ iterations.

Table 2.1 summarizes the five parameters needed for the optimizer, and it also specifies the domains the values should be selected from. In the next chapter this list will be supplemented with arguments describing the input data, and the enlarged list will be used in the image reconstruction.

\begin{tabular}{lcc}
\hline Parameter & Notation & Domain \\
\hline initial temperature & $T^{(0)}$ & $\mathbb{R}^{+}$ \\
cooling factor & $h$ & $(0,1) \subset \mathbb{R}$ \\
number of iterations for the variance calculation & $v$ & $\mathbb{Z}^{+}$ \\
number of modifications in a run & $N_{a t t}$ & $\mathbb{Z}^{+}$ \\
number of rejected modifications in a run & $N_{r e j}$ & $\mathbb{Z}^{+}$ \\
\hline
\end{tabular}

Table 2.1: Parameters of SA.

\subsection{Summary}

After giving a brief survey of tomography and DT, the chapter introduced the new pixel-based stochastic reconstruction technique that was designed for the reconstruction of digital images by using a limited number of projections, and where the range of the reconstructed image function contains just a small number of known intensity levels. Here the author presented the objective functional whose minimum location provides the reconstruction result, and described how the SA optimizer was employed for the minimization of the objective. In addition, as the original technique was devised for binary images only, he also provided two possible extensions to allow the method to reconstruct images containing more than two intensity values. 


\section{Chapter 3}

\section{Simulations}

In this chapter we present the simulation system developed to test the reconstruction technique in a simulation environment. It incorporates the experiences gained using software phantoms under both noiseless and noisy circumstances. In addition, we introduce the image reconstructions for the multi-level extension.

The author published his results and achievements in [17, 42, 43].

\subsection{The simulation system}

In order to examine the properties of the new pixel-based technique introduced in Section 2.3, a complete simulation system was implemented. The system has three main components related to the three major tasks encountered during the study. These are the

- generation of projections,

- image reconstruction,

- evaluation and visualization of the results.

The way these tasks are related to each other and what data flows between them will be described in Chapter 7 in more detail. Chapter 7 will also present the format of the DIRECT file interface, which was designed to contain all the data necessary to control the components and to enable inter-component communication.

\subsubsection{Generation of projections}

In the early stage of the research work, neither simulated nor real projections were available, but it was necessary to have input data to perform the simulation tests. To resolve this problem, a software component was developed that allowed one to generate parallel projections of an arbitrary digital image by accepting the digital image $(f)$ itself, a list of projection angles (see $\vartheta$ in Eq. 2.1) and the number of projection lines per projection as input parameters. Based on these arguments, this component calculated the set of corresponding $P_{\vartheta_{1}}, P_{\vartheta_{2}}, \ldots, P_{\vartheta_{m}}$ projection vectors. 
In real life conditions the projections are mostly taken equiangularly, so from here on it will be assumed that $\vartheta_{i}-\vartheta_{i+1}=\Delta_{\vartheta}$ and $m \cdot \Delta_{\vartheta}=180^{\circ}$ for all $i=$ $1,2, \ldots, m-1$. In practice, the neighbouring parallel projection lines are usually considered to be equidistant too, hence they will be calculated accordingly as well.

\section{Statistical noise}

In order to simulate the physical conditions, this component was designed to simulate the biggest degrading effect the physical projections are distorted by, hence here some noise was added to the generated projections. The proper noise model depends on the way the measurements in the physical projections are acquired (radiation type, detector type, physical filters, etc.), which is the subject of the very active field of signal processing. In this study the author settled for additive Gaussian noise, which can be characterized by its standard deviation $\sigma$, while the mean value of the distribution is conventionally set to 0 .

In the case where $\sigma$ is a non-zero number, a noise generator routine produces the vectors $\Xi_{1}, \Xi_{2}, \ldots, \Xi_{m}$, where $\Xi_{i}=\left(\xi_{i, 1}, \xi_{i, 2}, \ldots, \xi_{i, d}\right)$ and $\xi_{i, j}(1 \leq j \leq d, 1 \leq i \leq m)$ is a probability variable of the Gaussian distribution type having 0 mean and $\sigma$ standard deviation. Next, the routine creates the new set of $P_{\vartheta_{1}}^{\prime}, P_{\vartheta_{2}}^{\prime}, \ldots, P_{\vartheta_{m}}^{\prime}$ projections, where $P_{\vartheta_{i}}^{\prime}=P_{\vartheta_{i}}+\Xi_{i}$.

The list of parameters needed for generating noisy projections and their domains is summarized in Table 3.1.

\begin{tabular}{lcc}
\hline Parameter & Notation & Domain \\
\hline 2-dimensional digital image & $f$ & $\mathbb{Z}^{+} \times \mathbb{Z}^{+} \rightarrow D$ \\
angles of the projections & $\vartheta_{1}, \vartheta_{2}, \ldots \vartheta_{m}$ & $\mathbb{R}$ \\
& & $\left(m \in \mathbb{Z}^{+} \backslash\{1\}\right)$ \\
number of projection lines per projection & $d$ & $\mathbb{Z}^{+}$ \\
standard deviation of Gaussian noise & $\sigma$ & $\mathbb{R}^{0,+}$ \\
\hline
\end{tabular}

Table 3.1: Parameters of the projection generator.

\subsubsection{Reconstruction}

The input parameters of the reconstruction component can be divided into two groups. First, the module receives the projections and its parameters coming from the projection generation phase (see Table 3.2). Second, some additional parameters have to be set for the optimizer. The latter parameters and the corresponding domains were given in Table 2.1. When the reconstruction procedure terminates, the component produces the reconstruction result denoted by $\dot{f}$ in earlier sections.

\subsubsection{Evaluation and visualization}

After completing the reconstruction, the third task is the visualization of the results and the extraction of quantitative measurements that verify the goodness of the 


\begin{tabular}{lc}
\hline Parameter & Notation \\
\hline angles of the projections & $\vartheta_{1}, \vartheta_{2}, \ldots \vartheta_{m}$ \\
number of projection lines per projection & $d$ \\
projections & $P_{\vartheta_{1}}, P_{\vartheta_{2}}, \ldots, P_{\vartheta_{m}}$ \\
\hline
\end{tabular}

Table 3.2: Parameters of the projection set.

resultant images as well as the efficiency of the technique. The data visualization options are given in Chapter 7. It is just mentioned here that the image reconstructions in this thesis are presented in a popular 256-level lossless image format.

In order to measure the accuracy of the reconstruction quantitatively, three error indicators were tested, namely the mean square error, relative mean error and shape error [36]. It was found that the relative mean error (RME for short) is the most suitable indicator for showing the discrepancy between the original image and its reconstruction.

\section{RME for binary images}

Let $f^{\circ}$ and $f^{\mathrm{r}}$ be two discrete functions over a $h \times h$ lattice set, where $f^{\mathrm{o}}$ has at least one non-zero element. The RME for binary images is defined by the formula

$$
\operatorname{RME}\left(f^{\mathrm{o}}, f^{\mathrm{r}}\right)=\frac{\sum_{i}\left|f_{i}^{\mathrm{o}}-f_{i}^{\mathrm{r}}\right|}{\sum_{i} f_{i}^{\mathrm{o}}} \cdot 100 \%,
$$

where $i=1, \ldots, h^{2}$, and $f_{i}^{\mathrm{o}}, f_{i}^{\mathrm{r}} \in\{0,1\}$ denote the value of the $i$ th pixel in the original image and reconstructed image, respectively. It is obvious that RME $\geq 0$, and $\mathrm{RME}=0$ holds if and only if $f_{i}^{\mathrm{o}}=f_{i}^{\mathrm{r}}$. It is also clear that a smaller value of RME indicates a better reconstruction result, and that the RME can exceed $100 \%$. The latter can be deduced directly from the formula when there are more misplaced pixels in $f^{\mathrm{r}}$ than the number of non-zero ones in $f^{\circ}$.

\section{RME for multi-level images}

The goodness of multi-level reconstructions was measured by an adapted variant of RME. A customization of Eq. 3.1 was necessary since the calculated value was dependent on the total intensity in the original image. This can be seen by assuming that $f^{\mathrm{o}_{1}}, f^{\mathrm{O}_{2}}$ and their reconstructions $f^{\mathrm{r}_{1}}, f^{\mathrm{r}_{2}}$ are such that $f_{i}^{\mathrm{O}_{1}}+c=f_{i}^{\mathrm{o}_{2}}$ and $f_{i}^{\mathrm{r}_{1}}+c=$ $f_{i}^{\mathrm{r}_{2}}$ for a fixed $c$ integer $\left(i=1, \ldots, h^{2}\right)$. That is, there is no discrepancy in the quality of the two reconstructions $f^{\mathrm{r}_{1}}$ and $f^{\mathrm{r}_{2}}$, and the numerator of $\operatorname{RME}\left(f^{\mathrm{o}_{1}}, f^{\mathrm{r}_{1}}\right)$ is equal to the numerator of $\operatorname{RME}\left(f^{\mathrm{o}_{2}}, f^{\mathrm{r}_{2}}\right)$. Under such a condition, if

$$
\sum_{i} f_{i}^{\mathrm{o}_{1}}<\sum_{i} f_{i}^{\mathrm{o}_{2}},
$$

then

$$
\operatorname{RME}\left(f^{\mathrm{o}_{1}}, f^{\mathrm{r}_{1}}\right)>\operatorname{RME}\left(f^{\mathrm{o}_{2}}, f^{\mathrm{r}_{2}}\right)
$$


indicating that $f^{\mathrm{r}_{2}}$ is a better result than $f^{\mathrm{r}_{2}}$.

To prevent it being dependent on the total intensities, the following formula was applied for multi-level images.

$$
\operatorname{RME}^{\mathrm{m}}\left(f^{\mathrm{o}}, f^{\mathrm{r}}\right)=\frac{\sum_{i}\left|f_{i}^{\mathrm{o}}-f_{i}^{\mathrm{r}}\right|}{\sum_{i}\left\lceil f_{i}^{\mathrm{o}}\right\rceil} \cdot 100 \%,
$$

where $\lceil$.$\rceil is the ceiling function, and it is used to compute the number of non-zero$ pixels in the original image. It is readily seen that $\mathrm{RME}^{\mathrm{m}}$ measures the ratio of intensity differences between the original and resultant images with the number of non-zero intensities in the original image. The smaller the pixelwise intensity differences between the original and result images, the lower an $\mathrm{RME}^{\mathrm{m}}$ is calculated.

\subsection{Preparations}

Since [66] only provides a rough guide for the parameter set-up used in the optimizer, a lot of effort went into the determination of suitable settings. In this section we will show how the initial parameter values were determined in an analytical fashion. We will also present the test environment, the test protocol, and the considerations made before constructing the two different software phantoms that were applied in the simulation tests.

\subsubsection{The test environment and protocol}

The simulation tests were run on a dual processor computer. Both processors were a $3.06 \mathrm{GHz}$ Intel ${ }^{\circledR} \mathrm{Xeon}^{\mathrm{TM}} \mathrm{CPU}$ with a $512 \mathrm{kB}$ cache. The PC had a $2 \mathrm{~GB}$ physical memory, but the reconstruction never used more than $100 \mathrm{MB}$ during the simulations.

As mentioned above, the reconstruction method is a statistical one, hence its robustness and efficiency cannot be judged from a single reconstruction. Accordingly, each parameter set-up was executed 50 times, so the author's simulation experience was based on average reconstruction results. It led to a remarkable amount of statistical data. For example, over 170 parameter configurations were examined just for the two-valued images, which meant that over 8500 binary reconstructions were performed.

Here for each parameter set-up the average timing information and the average RME of the resultant and original images are provided in terms of the varying parameter. Using the averages of these indicators helps shed light on the problematic hidden features of the reconstruction technique. However, in order to get a visual understanding of the charts and numeric data, some average resultant images are also presented. 


\subsubsection{The binary phantoms}

The first tests were performed for the simplest case, namely the class of binary images. Two kinds of phantom images with different geometrical properties were constructed, one of which can be seen in Figure 3.1(a). It contained circular shapes and had no edges parallel to the projection beams. The other one (Figure 3.1(b)) contained a square that had defects of varying sizes on its edges.

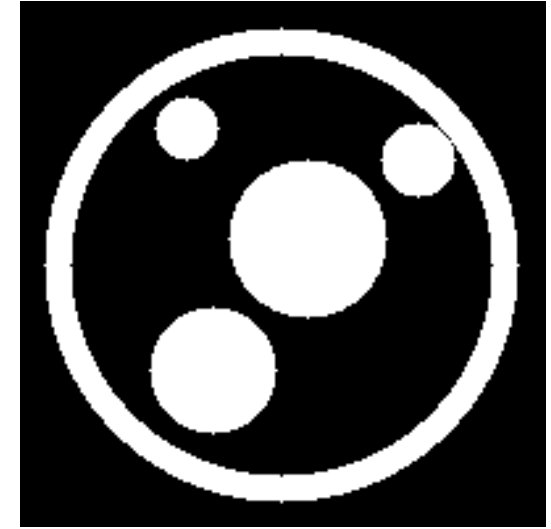

(a) Binary phantom image containing circle-shaped objects.

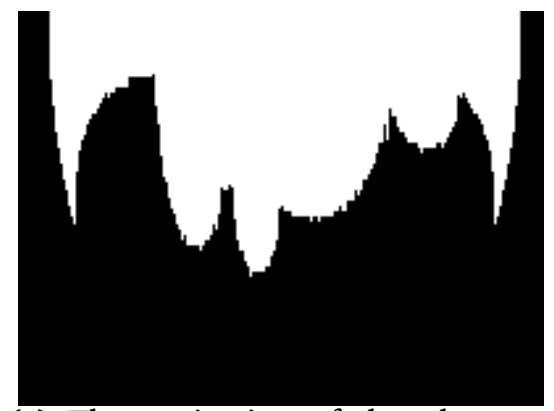

(c) The projection of the phantom seen in (a) taken at $180^{\circ}$.

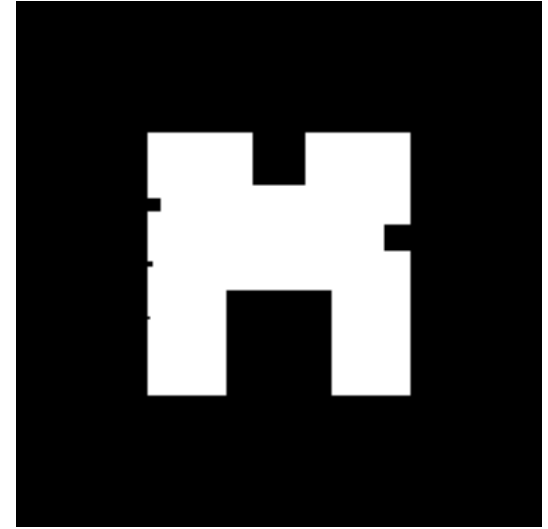

(b) Binary phantom image containing square-shaped objects.

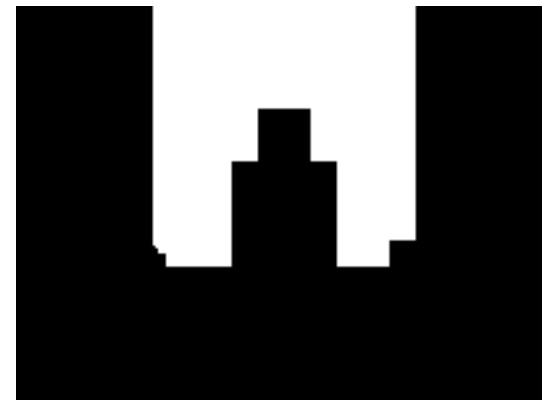

(d) The projection of the phantom seen in (b) taken at $180^{\circ}$.

Figure 3.1: The binary phantom images and one of their projections used for tests.

The reason why two phantoms were created comes from the following consideration: an object having edges parallel to the beams results in sharp gaps in the objective that may be easily discovered by the optimizer, even in the case of a suboptimal parameter set-up. (One such projection is shown in Figure 3.1(d).) In other words, when the phantom image comprises shapes with smooth projections, as in Figure 3.1(c), the optimizer has an uphill task due to the probably larger number of shallow local minima. Hence, the expectation was that the method would reveal a significant deviation in both performance (given by average run-time) and quality (measured by RME) depending on the phantom used, and a strong sensitivity should be observed for type of geometrical structure. It should confirm why the circular phantom is generally regarded as nearly the worst-case binary phantom. We had another goal with the square-shaped phantom. The defects in the edges could be used to see how the technique was able to cope with small details. 
Both phantom images were of dimensions $200 \times 200$. The circular one contained an annulus (with diameters 160 (inner) and 180 (outer) pixels) involving four disks (with diameters 60, 50, 30 and 25 pixels), as seen in Figure 3.1(a). The second image (see Figure 3.1(b)) comprised a square-shaped object and fulfilled the second aim, where the sizes of the defects were $40 \times 40,20 \times 20,10 \times 10,5 \times 5,2 \times 2$, and $1 \times 1$ in descending order.

It should also be noted here that the pixel intensities in the phantom images will be normalized to the $[0,1]$ interval, while the visualizations depict the natural grey-level image representation utilizing 256 values. That is, the phantom object itself is visualized by white pixels (intensity value 1), as long as the background is denoted by black ones (intensity value 0 ).

\subsubsection{Initial reconstruction parameters}

There is no general rule on the optimal SA parameter settings, so the initial tests were carried out by applying the values suggested below.

\section{Boltzmann constant and initial temperature $\left(\kappa, T^{(0)}\right)$}

Recalling Section 2.3, it was already found that $f^{\prime}$ is always accepted if $\Delta \Phi \leq 0$. Otherwise, $f^{\prime}$ is accepted according to the probability determined by the inequality

$$
e^{-\frac{\Delta \Phi}{\kappa T^{(i)}}}>\operatorname{RAND}(0,1)
$$

As for SA, in the case where $\Delta \Phi>0$, the optimizer should accept $f^{\prime}$ with a higher probability at the beginning of the optimization process. It means that the magnitude of $\kappa T^{(i)}$ in the exponent must be close to $\Delta \Phi$ to accept a sufficient number of bad configurations in the initial phase.

For this purpose, let us examine the parameters on the left hand side. $\Delta \Phi=$ $\Phi\left(f^{\prime}\right)-\Phi\left(f^{(i)}\right)$ tells us the difference caused by changing a single pixel intensity from 0 to 1 , or vice versa. The value of the difference is dependent on the number of beams crossing the pixel, the corresponding weights, and the intensity differences. (This latter is 1 for binary images made up of 0s and 1s.) When the distance between two neighbouring parallel projection beams is equal to the length of pixel edges in $f$, a rough upper bound can be determined for $\Delta \Phi$. Making this assumption, at most two beams cross a pixel. In this way, their aggregated weight cannot be greater than $2 a \sqrt{2}$; that is $0 \leq|\Delta \Phi|<2 a \cdot m \sqrt{2}$, where $a$ and $m$ denote the length of pixel edges and the number of projections, respectively. In the case of $a=1$ and 8 projections, $0 \leq|\Delta \Phi|<23$.

The expectation for Eq. 3.5 is that the left hand side should be sufficiently close to 1 in the initial iterations; that is, the quotient $\Delta \Phi / \kappa T^{(i)}$ should approach 0 at the beginning of the optimization. For instance, the choice of $\kappa T^{(i)}=10$ and $\Delta \Phi=23$ gives a value of 2.3. Then the left hand side of Eq. 3.5 has the value $\approx 0.1$, resulting in the acceptance of approximately $10 \%$ bad configurations.

It was mentioned in the preceding chapter that the separate specification of $\kappa$ and $T^{(0)}$ is unimportant, because only their product is involved in the optimization, 
and neither $\kappa$ nor $T^{(0)}$ is used at other points in the reconstruction algorithm. Hence the Boltzmann constant $\kappa$ can be set to 1 , while $T^{(0)}$ is the initial temperature value. In the binary tests, a value of $T^{(0)}=10$ was applied.

\section{Cooling factor $(h)$}

It is a good idea not to reduce the temperature too fast as it can cause the optimizer to get stuck in a local minimum. At the same time, $h$ should be kept as low as possible, otherwise the program will run for a long time. Therefore a 5-15\% reduction in temperature seems to be acceptable when the optimizer reaches an equilibrium state. We used $h=0.95$ for the simulation tests, but a higher value could be used for reconstructions from noisy projections.

For example, making the assumptions given in previous section, $h=0.95$ results in the acceptance of about $10 \%, 8.9 \%, 7.8 \%, 6.8 \%, 5.9 \%$ of bad configurations for the first five temperature levels.

\section{Number of $\Phi s$ used for equilibrium detection $(v)$}

This input parameter determines the number of recent objective values the variance has been calculated from (see Section 2.3.2). Needless to say, $v$ should be big enough to let the variances be stable values and reflect the equilibrium well. The choice was $v=5000$, which appeared to be satisfactory in practice.

\section{Efficiency parameters $\left(N_{a t t}, N_{r e j}\right)$}

Recall that these two parameters specify the termination criterion for the optimizer, and it means that the optimizer stops if at least $N_{r e j}$ configurations were rejected in the recent $N_{\text {att }}$ iterations. This criterion could also be expressed in other ways, but the original one described in [66] was employed in the technique. We chose $N_{a t t}=15000$ and $N_{r e j}=14999$. The efficiency is less than $10^{-4} \%$ in this case.

\subsection{Simulation studies}

It was necessary to examine the behaviour of the DT technique when the input parameters are adjusted within reasonable ranges. Becoming familiar with the nature of the parameters will enable one to see how to fine-tune the reconstruction when a poor result is obtained. In the analysis, the binary phantom images introduced in Section 3.2.2 were used. Apart from varying the values of a given parameter, the reconstruction technique was configured using the set-up given in Table 3.3.

\subsubsection{Number of projections}

Here, the author investigated how the number of projections influences the reconstruction results. To this end, 50 reconstructions were performed from $2,4,8,10$, $12,14,16$ and 18 projections using the circle-shaped binary phantom. 


\begin{tabular}{lcc}
\hline Parameter & Notation & Value \\
\hline number of projections used & $m$ & 16 \\
projection lines per projection & $d$ & 400 \\
initial temperature & $T^{(0)}$ & 10.0 \\
cooling factor & $h$ & 0.95 \\
number of iterations for the variance calculation & $v$ & 5000 \\
number of modifications in a run & $N_{a t t}$ & 14999 \\
number of rejected modifications in a run & $N_{r e j}$ & 15000 \\
noise & $\sigma$ & 0.0 \\
\hline
\end{tabular}

Table 3.3: Reconstruction parameters for simulation tests.

It was interesting to see how the objective values changed in terms of the iteration steps in the case of different numbers of projections being used. In Figure 3.2 each diagram contains 50 curves, and each of them belongs to a reconstruction. It is immediately apparent that the objective was nearly attained, but it never reached 0 (the perfect reconstruction) using 14 or fewer projections. That is, the method gets stuck in a local minimum, and the reconstruction terminated before it got out of it. Probably a smaller $N_{r e j} / N_{\text {att }}$ ratio would have been the remedy to this problem, but it would have resulted in a dramatic increase in the run-time. Nevertheless, 16 or more projections were already enough to recover the original phantom, which was clearly indicated by the curves reaching 0 in Figure 3.2(d). As seen, most of the reconstructions terminated in 20-50 million iteration steps, giving 200-1250 pixel modifications per reconstruction for a $200 \times 200$ image. It should also be remarked here that using a different reconstruction set-up and/or another phantom can result in a different number of projections needed for perfect reconstruction.

However, the diagrams in Figure 3.2 do not offer a ready comparison of the goodness of results for the different parameter configurations because the objective values greatly depend on the current parameter set-up and input data being investigated. For instance, a smaller objective value can also be achieved by reducing the number of projections, but it will probably lead to a marked drop in the reconstruction quality. Another problem is that 50 curves cannot be properly displayed on the same plot, so from now on goodness will be depicted by the average RME as a function of the parameter being investigated. One such diagram is shown in Figure 3.3(a).

Figure 3.3(a) tells us that by decreasing the number of projections to 16, the technique still gives perfect results for the circle-shaped object, while the reconstruction from 6 or fewer projections shows an increasingly marked discrepancy between the original and reconstructed objects. Between 8 and 16 projections, the RME increases, but remains at a moderate level, and the technique produces visually acceptable results (Figure 3.4). (A discussion of the square-shaped phantom results is given in the next section.)

A visualization of the results for $4,8,14$, and 16 projections can be seen in Figure 3.4. Evidently, the method was unable to give perfect reconstructions using 


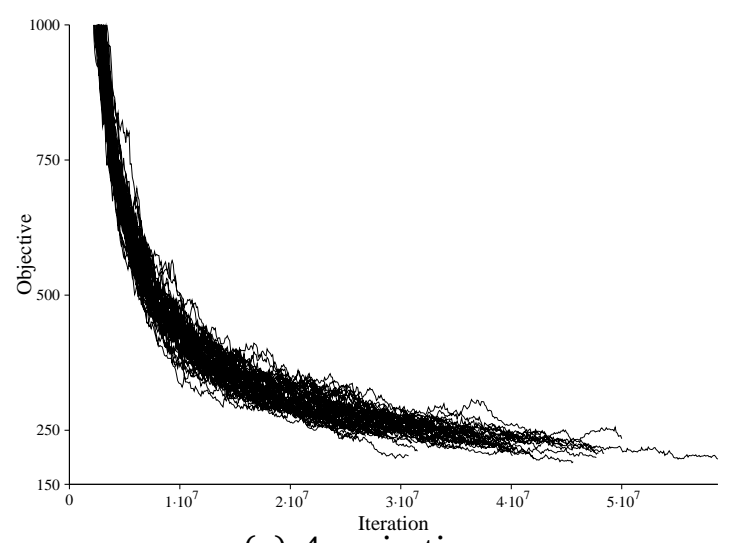

(a) 4 projections

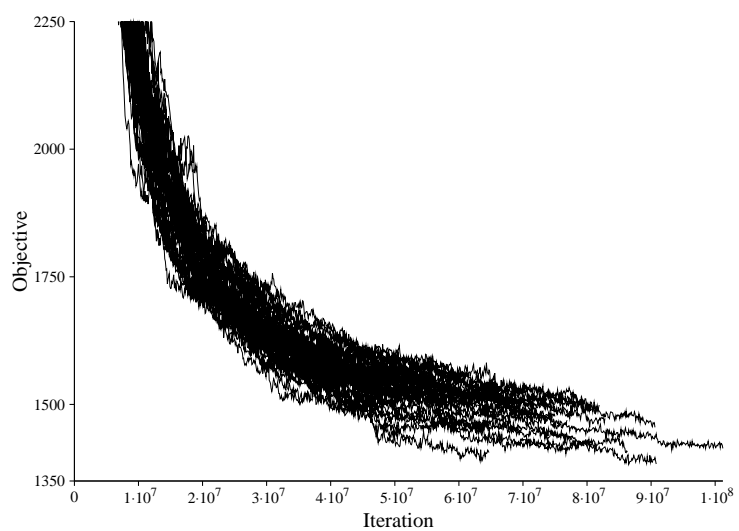

(c) 14 projections

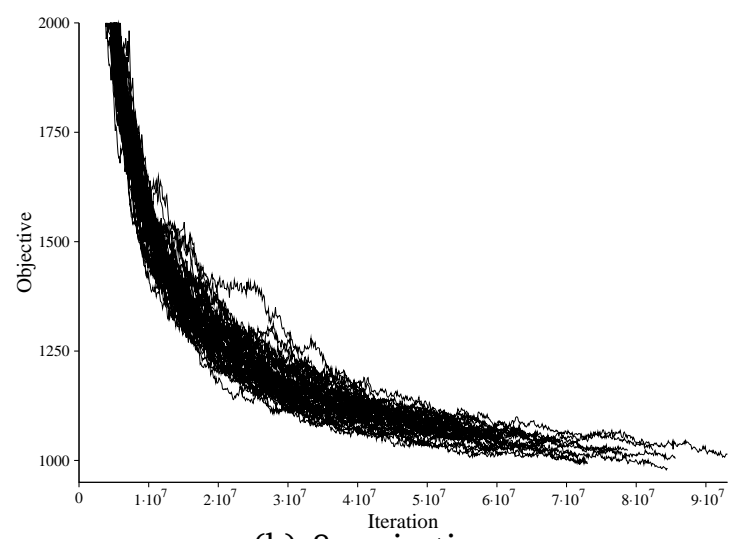

(b) 8 projections

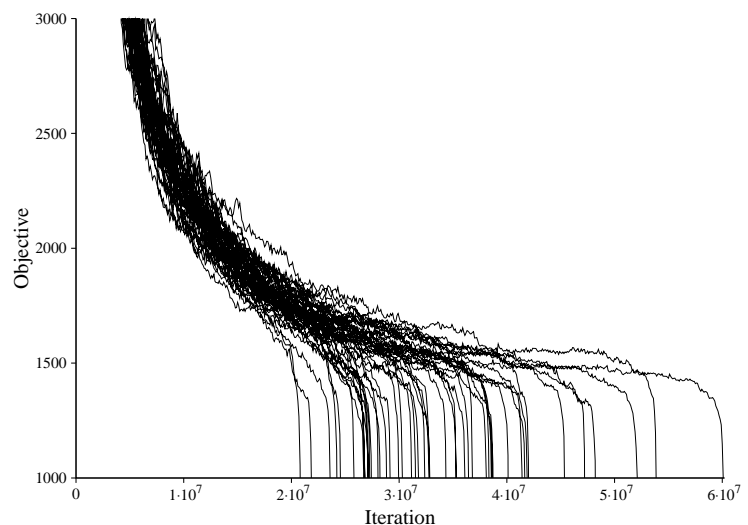

(d) 16 projections

Figure 3.2: Objective values as a function of iteration steps for different number of projections used for reconstruction.

4 or 8 projections, and even the projection directions could be determined for the images obtained from 4 projections. However, 14 and 16 projections were more than ample to provide 50 acceptable results.

From a timing point of view, Figure 3.3(b) indicates that the method terminated rapidly $(\approx 100$ seconds) when too few projections were used. A possible explanation for this might be that the objective functional was quite smooth using 2-6 projections. As mentioned above, a smaller $N_{a t t} / N_{r e j}$ would have been a solution to the problem, but it caused a significant rise in the reconstruction time. Thus efficiency involves a trade-off between the reconstruction time and quality.

Increasing the number of projections to 14 , the average reconstruction time rose to its maximum ( $\approx 600$ seconds). The amount of computations involved allows one to draw the conclusion that the optimizer often got stuck in local minima, but it eventually escaped from the valleys by finding better and better extrema. After reaching the peak value, the run-time drops to 100 seconds again. Noting the nearly perfect results, the optimizer has an easy task using an increased number of projections, which suggests that the objective has a deep and definite global minimum besides having several smaller local ones. 


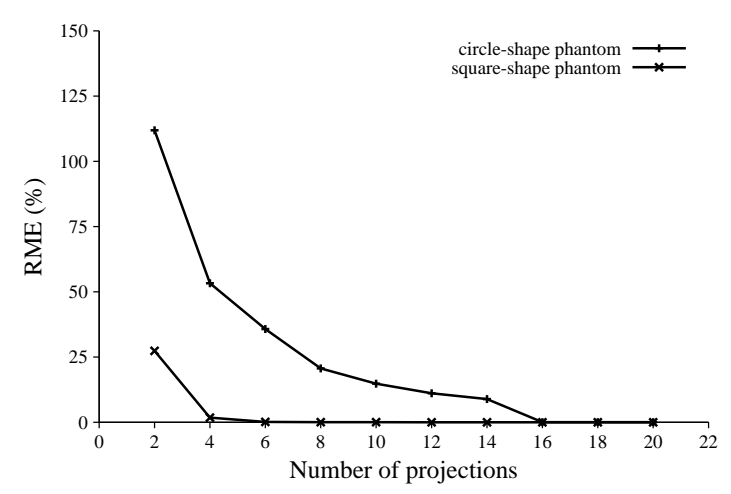

(a) Average RMEs of the reconstructions as a function of the number of projections.

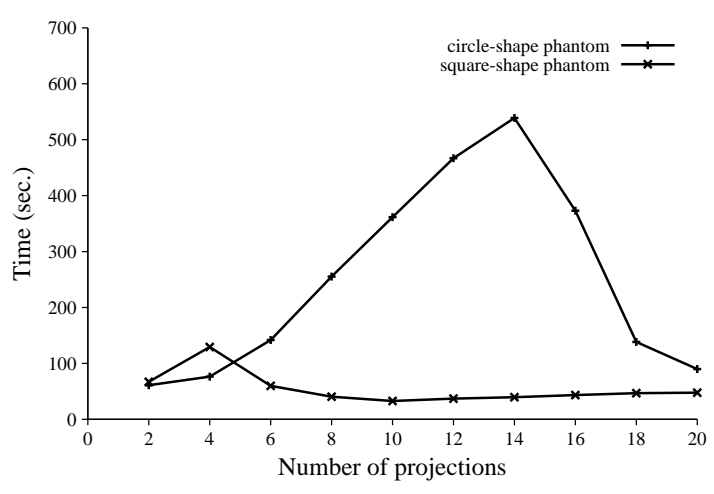

(b) Average run-time of the reconstruction as a function of the number of projections.

Figure 3.3: The average RME and run-time of both phantoms as a function of the number of projections.

\subsubsection{Geometrical properties}

In order to see how sensitive the method is to the geometrical properties of the object to be reconstructed, 'projection number' tests were also performed for the square-shaped phantom. The result was quite convincing when we observe the average image reconstructions in Figure 3.5 and the related parameter curves in figures 3.3(a)-(b). It can readily be seen that in the case of the square-shaped object the RME almost reaches 0 (a perfect reconstruction) just by using 6 projections, unlike the case of the other phantom, where at least 16 projections were necessary to achieve the same image quality. An explanation for this notable discrepancy lies in the geometrical properties. In figures 3.1(c)-(d) one sees that the projections of the circle-shaped phantom are smoother than those for the projections of the square-shaped phantom. In the latter case, there are big gaps in the projections, which can be easily found by the optimizer. The same effect was also observed in the timing data. The average run-times of square-shaped tests always remained below the values of circle-shaped phantom, apart from two cases $(m=2$ and $m=4)$. In general, the more projections there are parallel to the edges of the object, the easier it is for the optimizer to find a good solution. For instance, in Figure 3.4, the $0^{\circ}$ and $90^{\circ}$ projections are parallel to the vertical and horizontal edges for the directions specified in the definition of the Radon transformation.

The author's efforts to construct another phantom, which shows significantly worse reconstructability than the images containing circle-shaped objects, was unsuccessful. The same experience was also published in [71], hence the circle-shaped phantom can be reasonably considered to be practically a worst-case object for reconstruction.

As for its ability to resolve small details, the method was able to recover all the defects at the edges using just 6 projections, even the one that had the size of $1 \times 1$ pixel (see Figure 3.5(c)). This result offers hope that the method should always provide perfect noiseless reconstruction results if enough input data is available. 

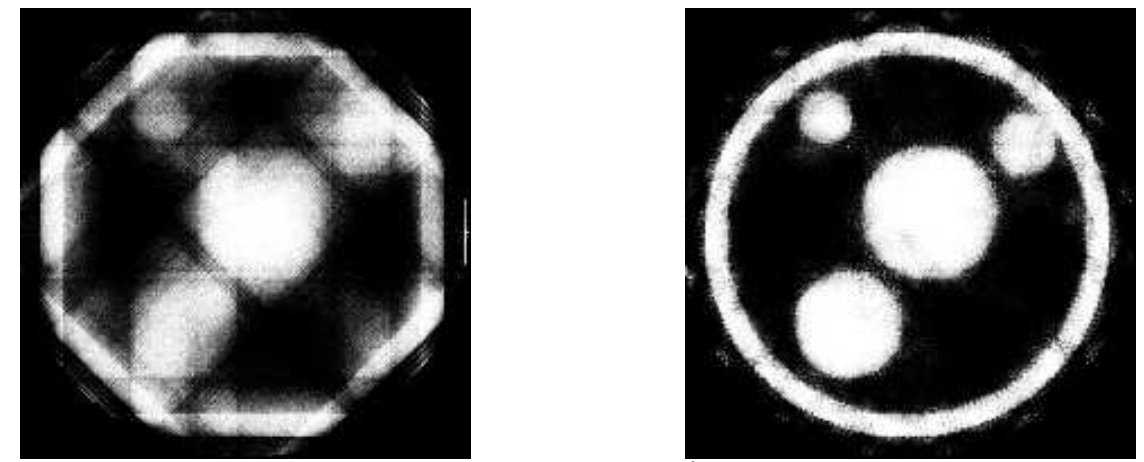

(a) 4 projections, average $\mathrm{RME}=53.2846$.
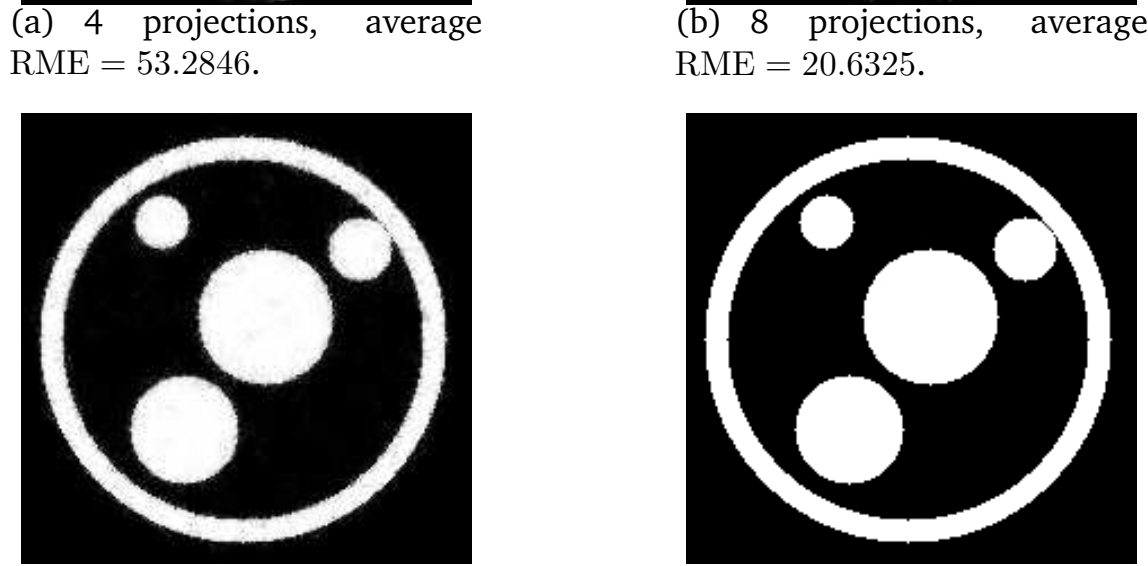

$\mathrm{RME}=20.6325$.

(c) 14 projections, average $\mathrm{RME}=8.8816$.

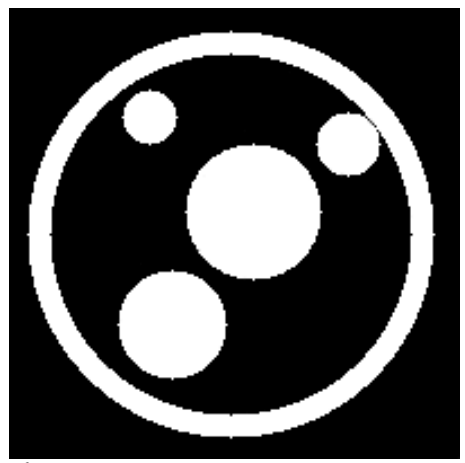

(d) 16 projections, average $\mathrm{RME}=0.0328$.

Figure 3.4: Average reconstruction results of circle-shaped phantom using different numbers of projections by the pixel-based DT method ( $\sigma=0$ noise, 400 measurements/projection).

\subsubsection{The $N_{r e j}$ and $N_{a t t}$ parameters}

An examination of the termination criterion was unavoidable as an improper choice of values could have adversely affected the termination of optimizer (i.e. premature termination), while the result might not be optimal. Therefore 13 tests were carried out using the circle-shaped phantom. $N_{a t t}$ was set to 15000 and $N_{r e j}$ took the values listed in the first column of Table 3.4. The third column gives the efficiency criterion, the ratio of rejected configurations (Eq. 2.22) in the last 15000 iterations.

The results in figures 3.6 and 3.7(a) indicate that the method provided good results when $N_{r e j}=13000$; that is, the optimizer terminated immediately when over $86.667 \%$ of the configurations were rejected. The timing data was also promising because the average run-time was always below 400 seconds. In addition, it clearly demonstrates that a better efficiency entails a longer reconstruction time.

It seems $N_{r e j}$ can be chosen from a relatively wide range such that $N_{r e j} / N_{a t t}$ is greater than about $85 \%$, and less than or equal to $100 \%$. Nevertheless, the result of this wide interval can be quite misleading, if we ignore a possible correlation among the reconstruction parameters. The fact that even an efficiency of $99.993 \%$ was insufficiently low for a good reconstruction from 4 projections (see Figure 3.4(a)) 


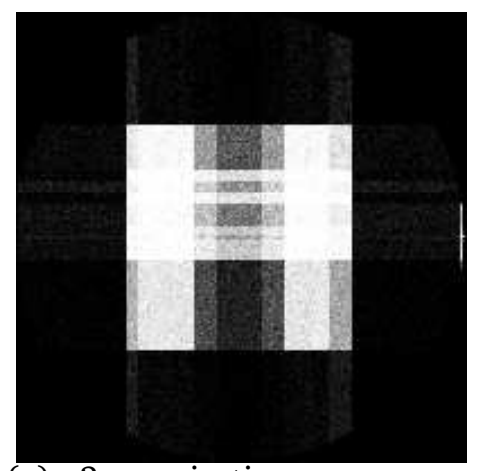

(a) 2 projections, average $\mathrm{RME}=27.3461$.

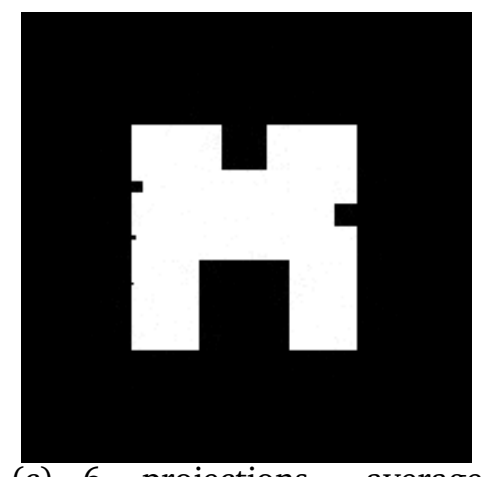

$\mathrm{RME}=0.1471$

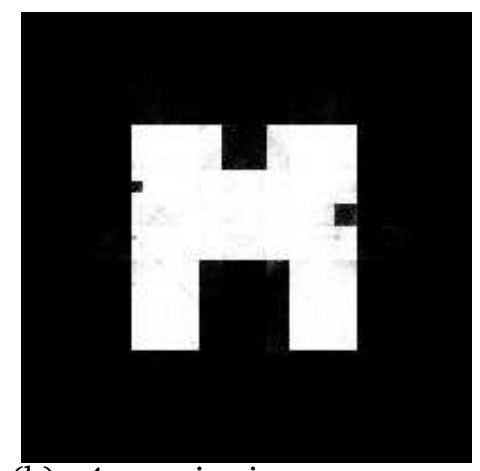

(b) 4 projections, average $\mathrm{RME}=1.7921$.

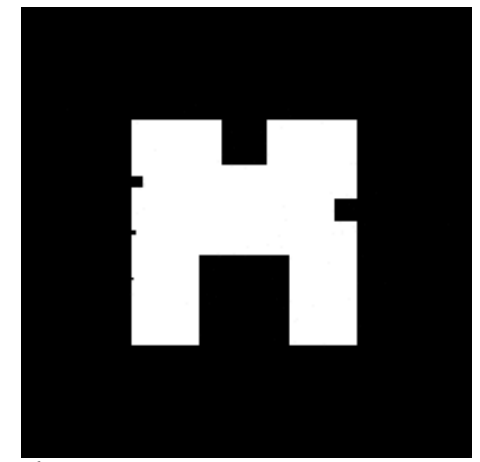

(d) 8 projections, average $\mathrm{RME}=0.0244$.

Figure 3.5: Average reconstruction results of the square-shaped phantom (using different numbers of projections) got by using the pixel-based DT method ( $\sigma=0$ noise, 400 measurements/projection).

\begin{tabular}{lcc}
\hline$N_{r e j}$ & $N_{\text {att }}$ & $\begin{array}{c}\text { Termination criterion } \\
\left(\frac{N_{\text {rej }}}{N_{a t t}} \cdot 100 \%\right)\end{array}$ \\
\hline 500 & 15000 & 3.333 \\
1000 & 15000 & 6.667 \\
2500 & 15000 & 16.667 \\
5000 & 15000 & 33.333 \\
7500 & 15000 & 50.000 \\
10000 & 15000 & 66.667 \\
13000 & 15000 & 86.667 \\
14000 & 15000 & 93.333 \\
14500 & 15000 & 96.667 \\
14900 & 15000 & 97.333 \\
14990 & 15000 & 99.933 \\
14995 & 15000 & 99.967 \\
14999 & 15000 & 99.993 \\
\hline
\end{tabular}

Table 3.4: Termination criteria investigated in simulation tests. 
leads one to conclude that the smaller number of projections requires a higher efficiency, and the $N_{r e j} / N_{a t t}$ ratio should be set as high as practically possible. Empirically, $N_{r e j}=14999$ appeared to be a good value assuming that $N_{a t t}=15000$.

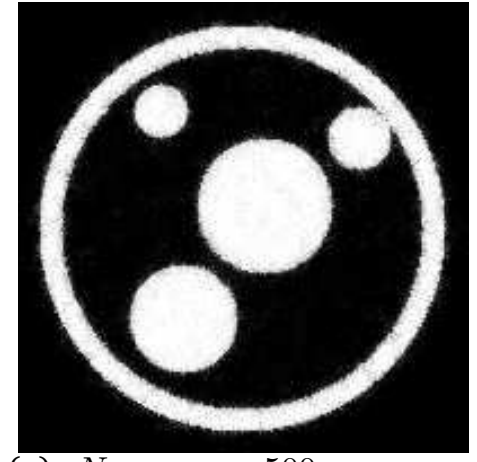

(a) $N_{r e j}=500$, average $\mathrm{RME}=13.3809$.

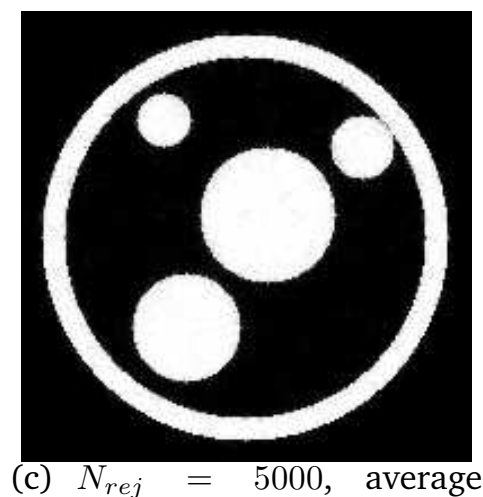

$\mathrm{RME}=5.5738$.

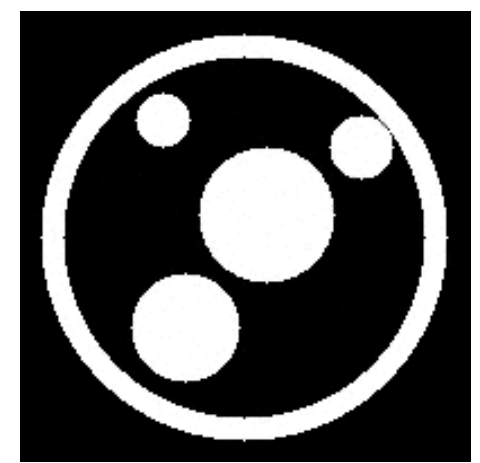

(e) $N_{r e j}=14990$, average $\mathrm{RME}=0.1677$.

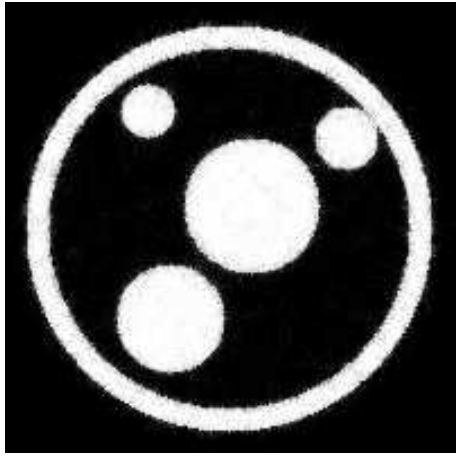

(b) $N_{r e j}=1000$, average $\mathrm{RME}=11.1922$.

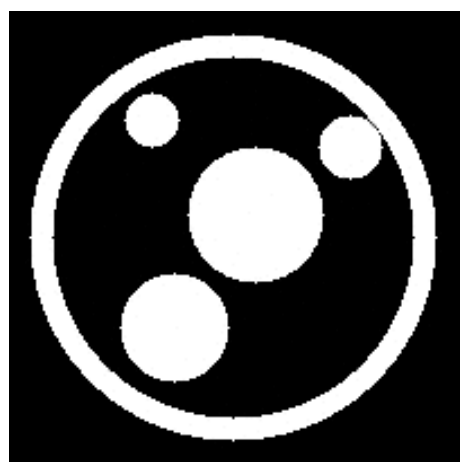

(d) $N_{r e j}=13000$, average $\mathrm{RME}=0.001791$.

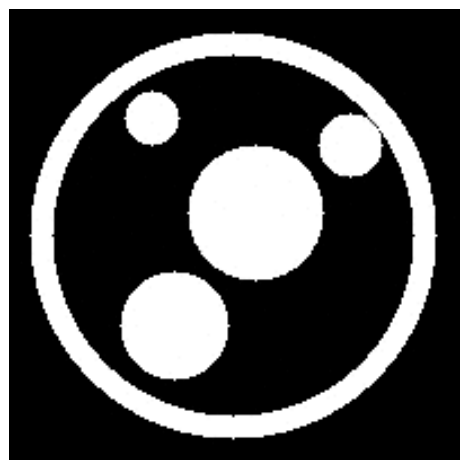

(f) $N_{r e j}=14999$, average $\mathrm{RME}=0.1331$.

Figure 3.6: Average reconstruction results of a circle-shaped object in the case of different values of $N_{r e j}$ for a fixed value of $N_{\text {att }}=15000$. ( $\sigma=0$ noise, 16 projections, 400 measurements/projection). 


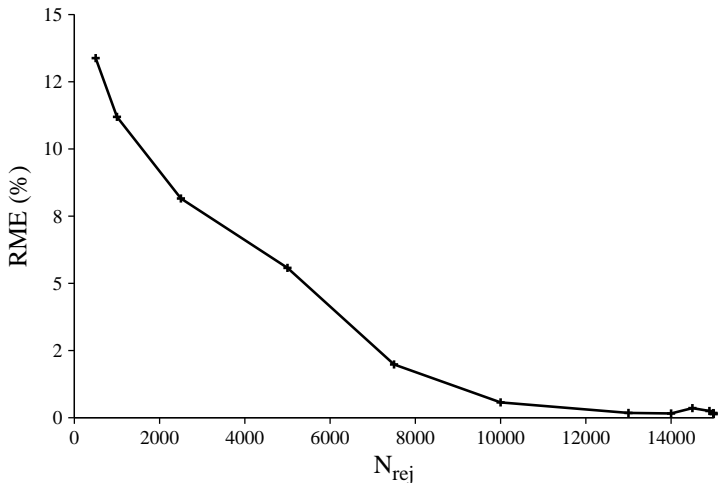

(a) Average RME as a function of $N_{r e j}$.

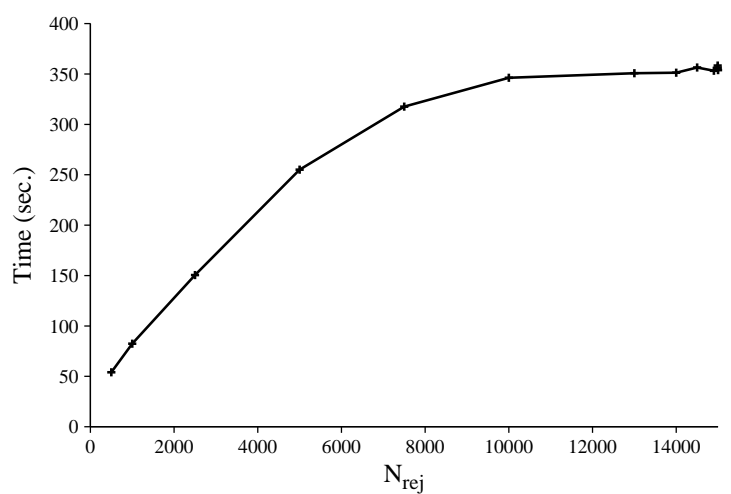

(b) Average run-time as a function of $N_{r e j}$.

Figure 3.7: The average RME and run-time as a function of $N_{r e j}$ using the circle-shaped phantom.

\subsubsection{Initial temperature}

In the tests, values of $0.000001,0.001,0.5,1.0,2.0,3.0,4.0,10.0,20.0,50.0$, 100.0 and 1000.0 degrees centigrade were applied as the initial temperature. Our early consideration was the following. If the initial temperature is high, the method runs for a long of time. However, if $T^{(0)}$ is too low, the optimizer gets stuck in a local minimum and this yields a bad result. The danger of the latter is more apparent when the phantom is a multi-level image. To verify the above-mentioned intuitions, we plotted the average RME and the reconstruction time as the function of the initial temperature on a log-scaled horizontal axis in Figure 3.8. In addition, the average reconstructions for $T^{(0)}=0.000001,0.001,0.5,1.0$ are displayed in Figure 3.9.

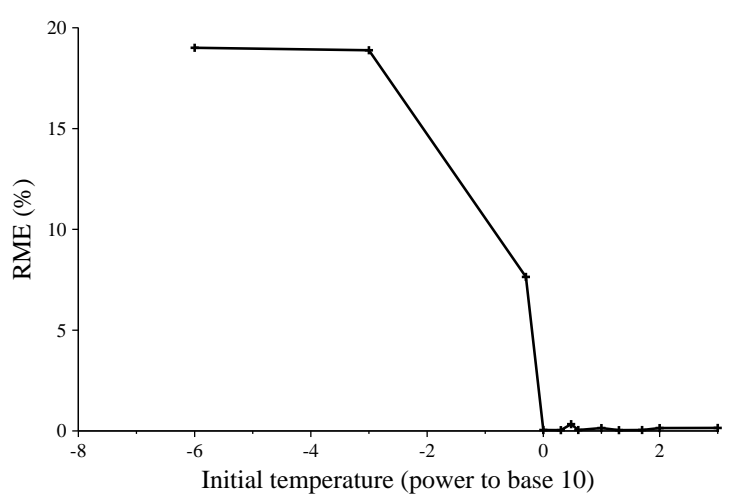

(a) Average RME as a function of the initial temperature.

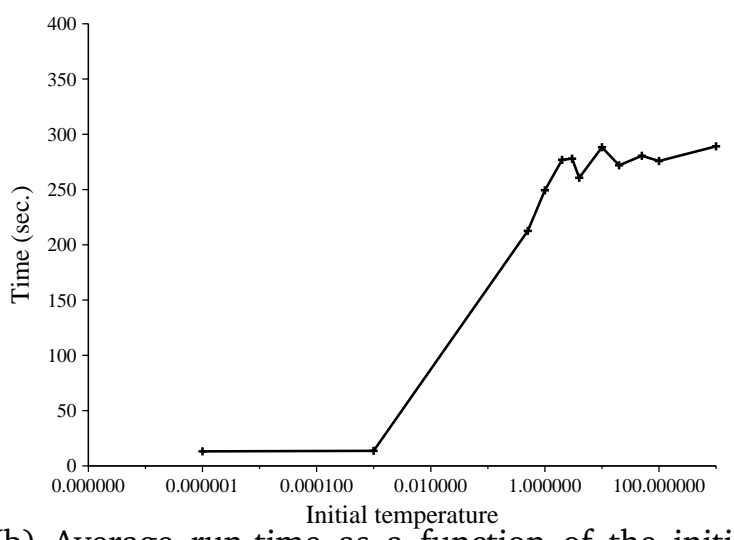

(b) Average run-time as a function of the initial temperature using a log-scaled horizontal axis.

Figure 3.8: The average RME and run-time as a function of the initial temperature.

From (a) and (b) in Figure 3.8, the conclusion can be drawn that a temperature of less than one centigrade leads to unsuccessful reconstructions because the op- 
timizer gets stuck in a local minimum, and the temperature was not high enough for the optimizer to get out of it. However, it was unusual that the run-time did not go up dramatically when the initial temperature was increased in steps to 1000 centigrade. This can be attributed to the fact that the equilibrium state is attained relatively quickly at a higher temperature than at a lower one, and $T^{(i)}$ falls rapidly at the beginning.

The sudden rise in the reconstruction time between $T^{(0)}=0.001$ and $T^{(0)}=1.0$ (Figure 3.8(b)) shows that there is a critical level for the initial temperature where the technique can perform a worthwhile optimization. At the same time, if the optimizer gets stuck in deep local minima, it may take many iterations to get out of them due to the relatively low initial temperature.

Overall, it can be said that the minimum initial temperature is about 1-10 degrees centigrade for binary images, but it is still alright if a higher initial temperature value is chosen.

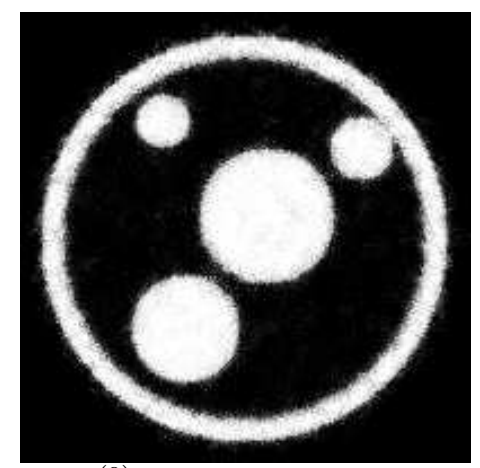

(a) $T^{(0)}=0.000001$, average $\mathrm{RME}=19.0067$.

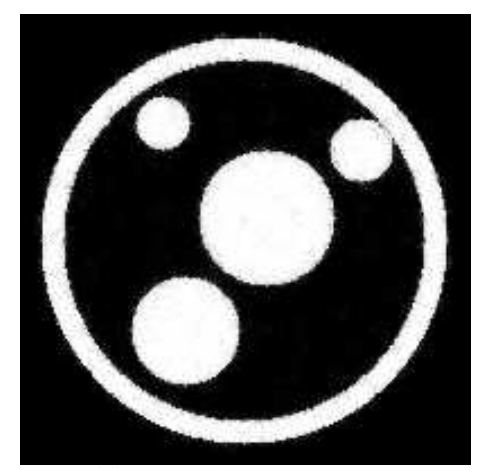

(c) $T^{(0)}=0.5$, average $\mathrm{RME}=$ 7.6389.

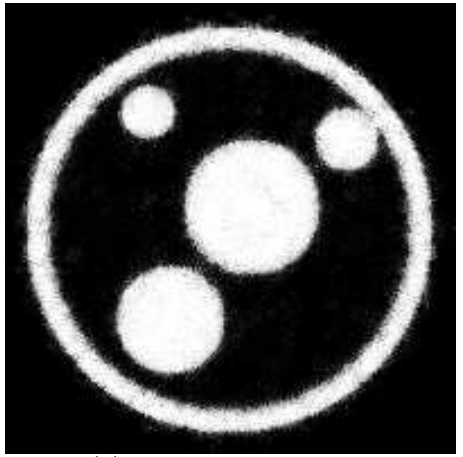

(b) $T^{(0)}=0.001$, average $\mathrm{RME}=18.8843$.

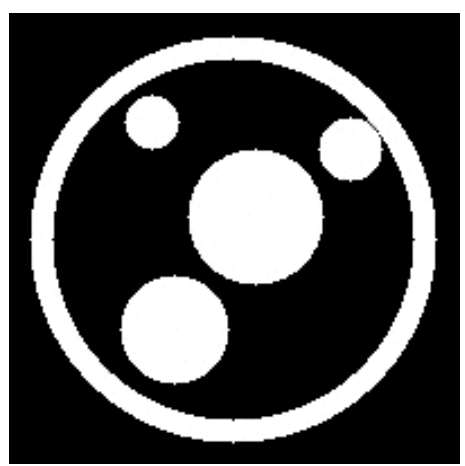

(d) $T^{(0)}=1.0$, average $\mathrm{RME}=$ 0.0426 .

Figure 3.9: Average reconstruction results of a circle-shaped object using different initial temperatures ( $\sigma=0$ noise, 16 projections, 400 measurements/projection). 


\subsubsection{Cooling factor}

Another essential parameter that affects the optimizer's performance is the cooling factor $h$. When $h$ is small, the temperature falls too quickly, and the optimizer can easily find itself stuck in a local minimum, providing a solution that is different from the global optimum (i.e. the solution is a sub-optimal). In contrast, if $h$ is big, the temperature falls slowly, and it leads to a long-running reconstruction process. Since $h \in(0,1)$, a small/big $h$ means a value near to $0 / 1$, respectively. It is not hard to see that $h=1.0$ leaves $T^{(i)}$ unchanged, while $h=0$ quickly turns the technique into a deterministic optimization, hence it was reasonable to exclude these values from the investigations. Nonetheless, for the sake of curiosity and completeness, the RME and timing results also include the $h=1.0$ case.

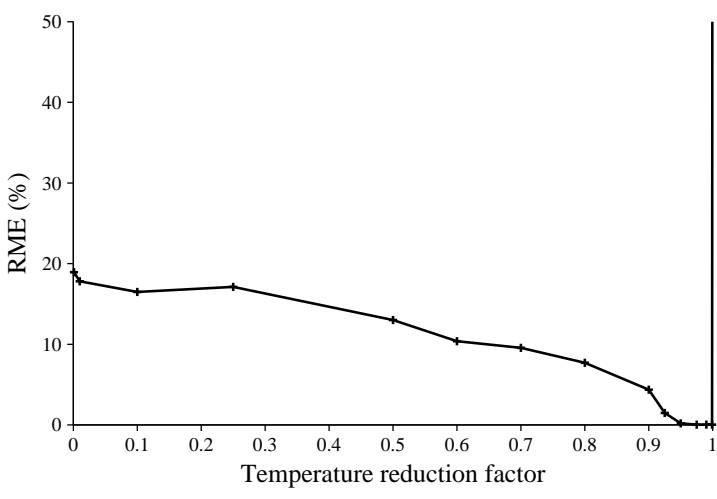

(a) Average RME as a function of the cooling factor.

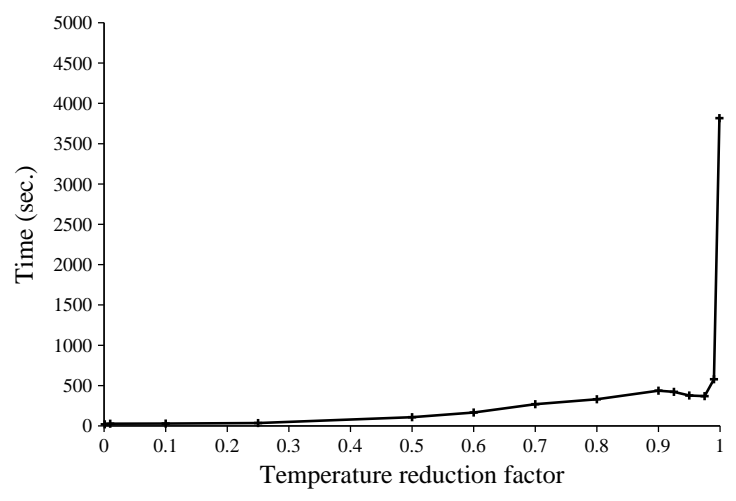

(b) Average run-time as a function of the cooling factor.

Figure 3.10: The average RME and run-time as a function of the cooling factor $(h)$.

15 tests were performed where $h$ took the values $0.001,0.01,0.1,0.25,0.5,0.6$, $0.7,0.8,0.9,0.925,0.95,0.975,0.99,0.999$ and 1.0 , respectively. With Figure 3.10(a) a monotonous decrease can be observed in the RME while $h$ is increasing. This is probably due to the fact that the higher the $h$ value, the better the chance that the optimizer can get out of local minima and not get stuck in one. The RME noticeably approaches zero only when $h$ rises above 0.9 , and a visually acceptable result (see Figure 3.11) could be achieved when $h=0.925$.

The timing aspect of the reconstruction displays a definite increase until $h$ reaches 0.9 , when it turns into a slow fall between 0.9 and 0.99 . The RME values and the decrease in the run-time near $h=0.9$ allow one to conclude that a reasonable choice of $h$ should be in the interval $[0.95,1.0)$.

\subsubsection{Effect of noise}

Real tomographic measurements always contain a certain amount of noise. The goal, of course, is for the reconstruction method to be applicable in real circumstances, so testing with noise present is indispensable in phantom experiments. 


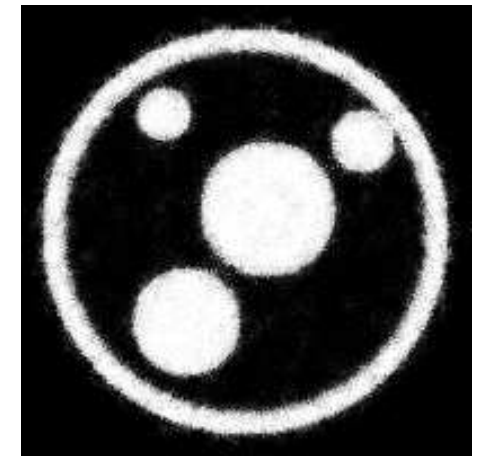

(a) $h=0.001$, average RME = 18.9356 .

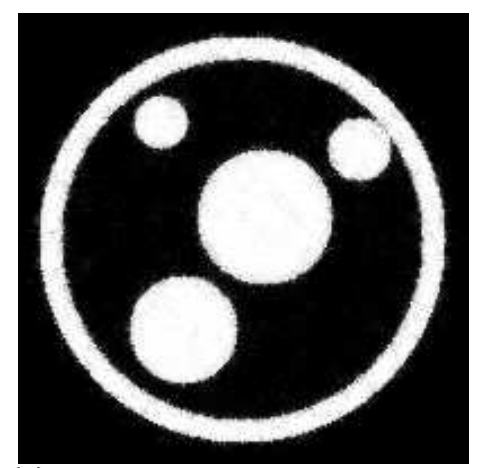

(c) $h=0.6$, average RME = 10.3826 .

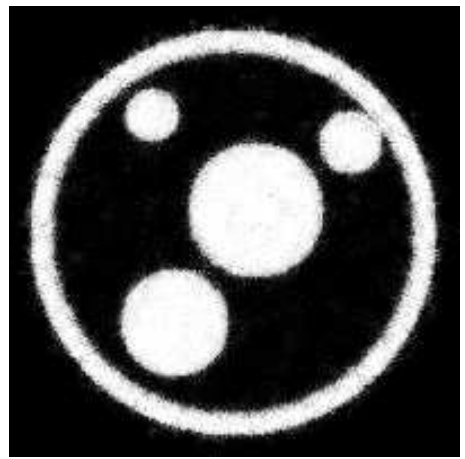

(b) $h=0.25$, average RME $=$ 17.1116 .

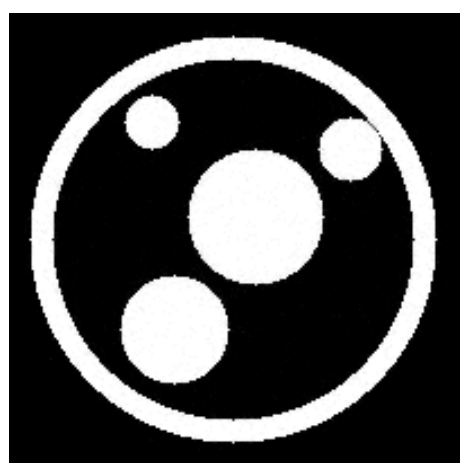

(d) $h=0.925$, average RME $=$ 1.4861 .

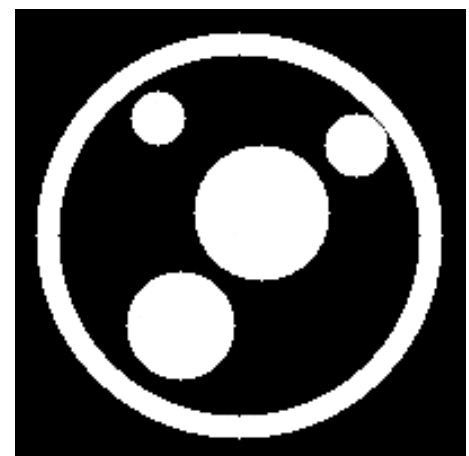

(e) $h=0.975$, average RME $=$ 0.0354 .

Figure 3.11: Average reconstruction results of a circle-shaped object using different cooling factor values ( $\sigma=0$ noise, 16 projections, 400 measurements/projection). 
The noise generator used for the simulations was introduced in Section 3.1.1. Accordingly, different amounts of Gaussian noise that had a mean of 0.0 were added to the exact projections. In the test cases the standard deviation took the values $\sigma=0.5,1.0,2.0,5.0,10.0,15.0,20.0,30.0,40.0$ and 100.0, respectively. For the sake of illustration, some noisy projections are displayed in Figure 3.12.

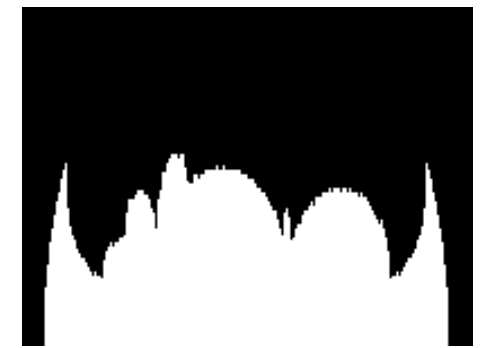

(a) Noiseless.

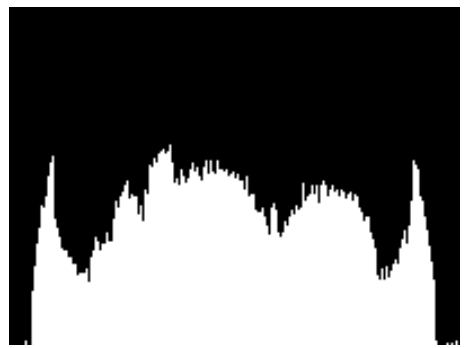

(c) $\sigma=5$.

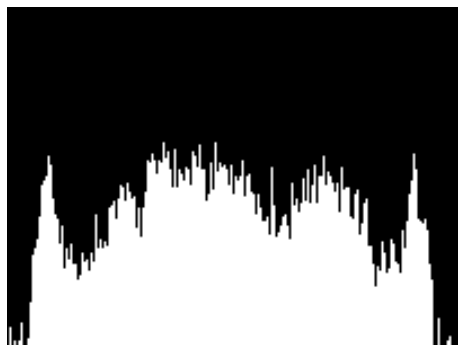

(e) $\sigma=40$.

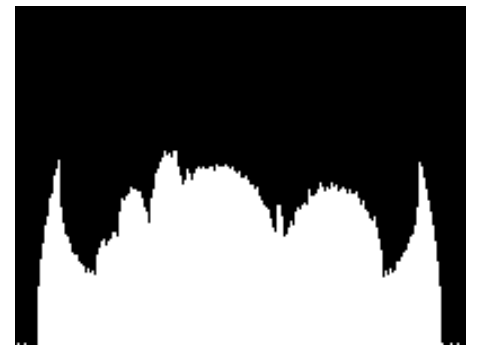

(b) $\sigma=1$.

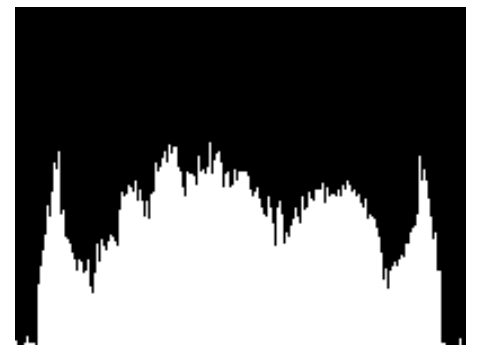

(d) $\sigma=10$.

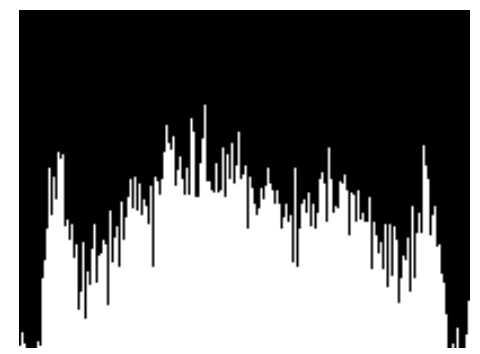

(f) $\sigma=100$.

Figure 3.12: $0^{\circ}$ projections of the square-shaped object corrupted by applying different amounts of additive Gaussian noise.

Typical average reconstruction results from the noisy projections are seen in Figure 3.13. As expected, the increasing amount of noise degrades the quality of the resultant images, which is readily reflected in the RME values in Figure 3.14(a). The RMEs show that even a small $(\sigma=0.5)$ additive noise component introduces a $10 \%$ increase in the RME, and that an exponential-like relation can be observed between the amount of noise and the RME. In spite of this relation, the RME remained below 50\% even in the case when $\sigma$ was 100.0. Evidence for the robustness of the reconstruction method is provided by the fact that the original object is recognizable even in the case where $\sigma=100.0$. The efforts made and results obtained for noise reduction are presented in Section 3.4.

Though Eq. 2.16 has a theoretical minimum of zero, here we cannot expect the 


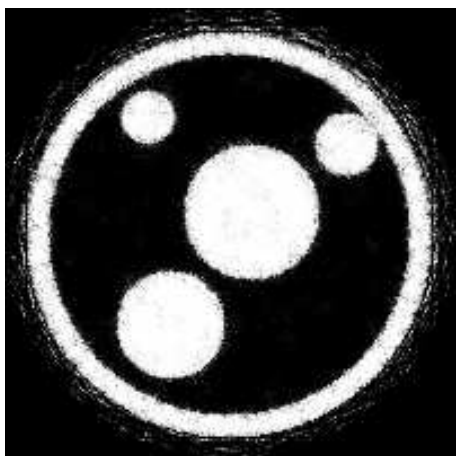

(a) $\sigma=1.0$, average $\mathrm{RME}=$ 15.9656

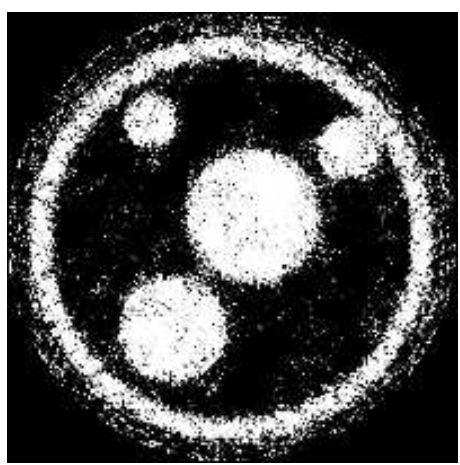

(c) $\sigma=40.0$, average $\mathrm{RME}=$ 32.5555 .

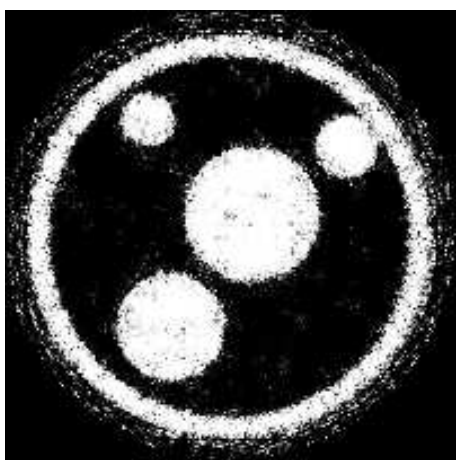

(b) $\sigma=10.0$, average $\mathrm{RME}=$ 22.9545 .

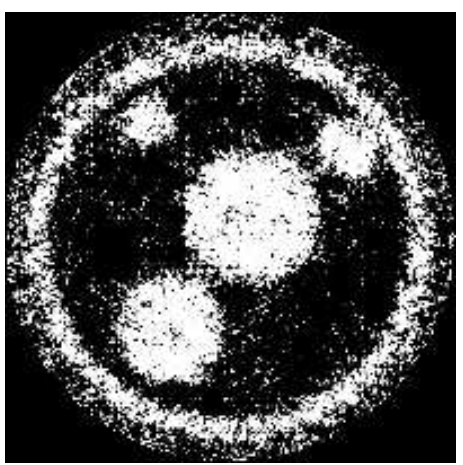

(d) $\sigma=100.0$, average $\mathrm{RME}=$ 46.7418 .

Figure 3.13: Average reconstruction results for circles with noisy projections (16 projections, 400 measurements/projection).

objective functional to attain it. Noisy projections are usually inconsistent, hence only a 'nearly perfect' reconstruction can be obtained; that is $\Phi(\dot{f})>0$, where $\Phi$ is the objective functional and $\dot{f}$ is the reconstruction outcome.

As regards the timing statistics summarized in Figure 3.14(b), it can be said that there is no significant run-time increase or decrease when the amount of noise added is varied. However, as the reconstruction technique is sensitive to a number of factors (e.g. geometrical properties and number of projections used), it should be mentioned that the method can produce different plots for a different phantom.

\subsection{Reduction of the noise effects}

In the previous section it was described how an additive noise source influences the reconstruction result. Now a feasible solution is given for overcoming this distorting effect. Since, especially in the case of industrial objects, it may often be assumed that the cross-section to be reconstructed contains contiguous regions of the same intensity, the smoothness property was the most obvious a priori to be exploited. The regularized reconstructions from noisy projections [42] were carried out using the following mathematical description of smoothness: 


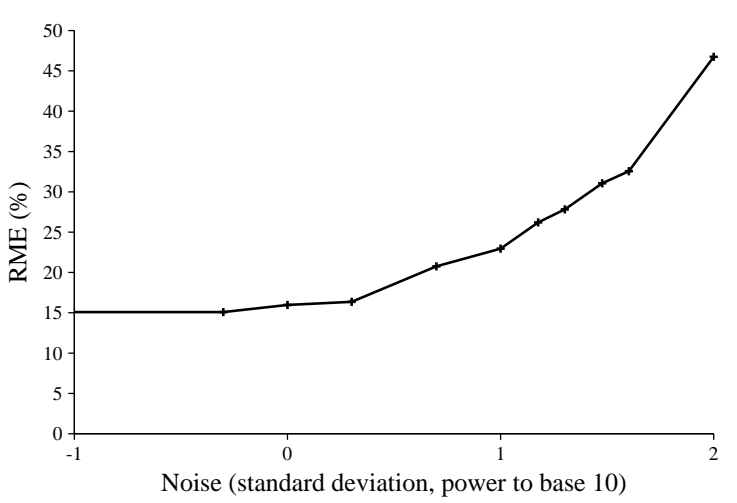

(a) Average RME as a function of noise.

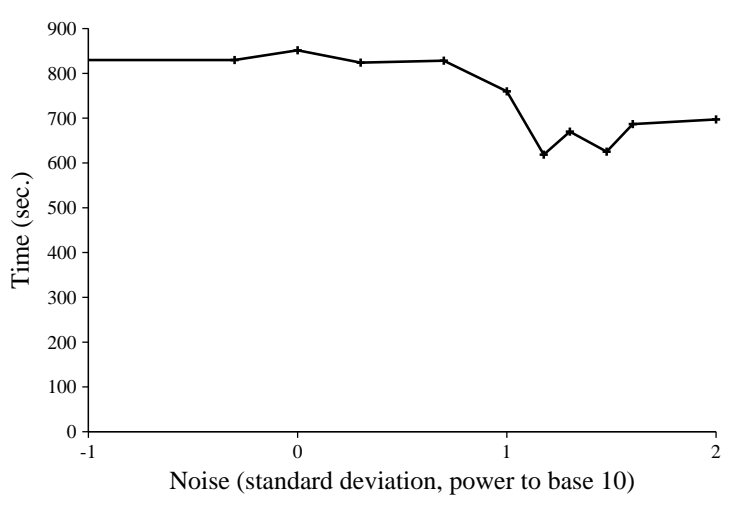

(b) Average run-time as a function of noise.

Figure 3.14: The average RME and run-time as a function of Gaussian noise added to the projections.

$$
\phi(f)=\sum_{x, y} \sum_{u, v}(f(x, y)-f(x-u, y-v)) \cdot \exp \left[-\frac{\left(u-\mu_{x}\right)^{2}}{2 \sigma_{x}^{2}}-\frac{\left(v-\mu_{y}\right)^{2}}{2 \sigma_{y}^{2}}\right] .
$$

This function penalizes the resultant images containing non-homogeneous regions, and prefers image functions that consist of large contiguous ones. In other words, Eq. 3.6 computes a bigger $\phi$ value for noisy/detail-rich image parts and a smaller one for smooth/homogeneous regions. The size of the smoothing kernel used in the tests was $5 \times 5$ and contained the discrete approximation of a Gaussian function characterized by $\sigma_{x}=\sigma_{y}=1.5$ and $\mu_{x}=\mu_{y}=0.0$. As smoothness is a local property of the image, the construction of bigger kernels is not worthwhile and it would lead to an increased amount of needless computations.

Here it should be noted that this regularization term is not universally applicable, especially when small details are important. The technique (due to the smoothing nature of Eq. 3.6) cannot distinguish between small details and noise, and annihilates them. In addition, the more noise the projections are corrupted by, the bigger the regularization coefficient should be used. However, a bigger coefficient can cause the removal of larger details as well. In spite of these considerations, the smoothing operator is a widely utilized technique in experimental tomography, and it is also applied in the ART reconstructions presented in Chapter 4.

The application of a regularization term raises some interesting issues. It is not hard to see that there is no $\gamma$ value that would be appropriate under every circumstance. However, is there an analytic way of determining the trade-off between the two terms in Eq. 2.16? Is there a way of normalizing the first term in Eq. 2.16? This is a hard problem, because the effect of $\gamma$ is dependent on the maximum value of the first term, which is a function of the reconstruction parameters (e.g. the number of projections and the number of projection lines). Furthermore, $\gamma$ is also dependent on the object to be reconstructed. Since this latter is unknown, only a rough upper bound can be given. 


\subsubsection{Noise reduction results}

In order to investigate how Eq. 3.6 diminishes the effect of noise, the behaviour of the method was tested with different combinations of noise amounts $(\sigma)$ and regularization coefficient values $(\gamma)$. Therefore $121(11 \times 11)$ test cases were performed by reconstructing the phantom in Figure 3.1(a) using the parameters listed in Table 3.5.

\begin{tabular}{lc}
\hline Parameter & Values \\
\hline$\sigma$ & $0.1,0.5,1.0,2.0,5.0,10.015 .0,20.0,30.0,40.0,100.0$ \\
$\gamma$ & $0.5,1.0,2.0,4.0,6.0,8.0,10.0,15.0,20.0,50.0,100.0$ \\
\hline
\end{tabular}

Table 3.5: Parameter values for noise reduction tests.

Figure 3.15 shows the computed average RMEs as a 3-dimensional plot. It tells us that if the regularization coefficient is greater than 30, the RME rapidly approaches $100 \%$. (Recall Section 3.1.3, where it was pointed out that the RME can be greater than 100\%.) This means that all the pixels in the reconstruction that should have been white were reconstructed incorrectly. The reason is that the penalty term suppressed the projection data, and the result became a homogeneous image containing the intensity value occurring the most frequently (black in this case) in the original image. It also should be added that $\gamma=30$ is not a general upper bound, because the effect of a fixed value of $\gamma$ depends on the input parameters. Nevertheless, the existence of such a $\gamma$ value can be taken for granted.

It is also evident in Figure 3.15 that the bigger the noise component in the projections (which corrupts them), the bigger the $\gamma$ value needed to get reconstruction results with a small RME. Still, $\gamma$ should not be increased too much due to the arguments mentioned above. There is a price to be paid for having a high $\gamma$ value. That is, combinations of regularization coefficients and noise amounts are preferred where the RMEs remain close to 0 , and $\gamma$ is as low as possible. For instance, the RME value is almost constant when $\sigma=0.5$ and $\gamma$ is taken from the interval $[1,10]$, but $\gamma=1$ is the preferred value.

From a run-time point of view (Figure 3.16), the utilization of the regularization term is an expensive tool. The reconstruction could cost up to 5000 seconds for cases when the smallest RME values were obtained $(\gamma=20.0)$, and a $2-8$ fold increase could be the result in the average run-times for the values given in Figure 3.14(b).

Next, the average reconstruction times display a sharp fall when $\gamma$ exceeds 30 . Taking a look at the graph in Figure 3.16, we recognize that the quick reconstruction can be accounted for by the overweighted $(\gamma>30.0)$ regularization term. It is the case when no effective reconstruction is performed, and the result is a homogeneous black image.

In order to get a graphical picture of robustness of the method under noisy conditions, the average reconstruction results for the different combinations of $\gamma \mathrm{s}$ and $\sigma$ s are displayed in figures 3.17, A.1, A.2 and A.3. Here $\sigma$ took the values 1.0, 10.0, 40.0 and 100.0, while $\gamma$ was investigated when $\gamma=1.0,4.0,10.0$ and 20.0. 
$\operatorname{RME}(\%)$

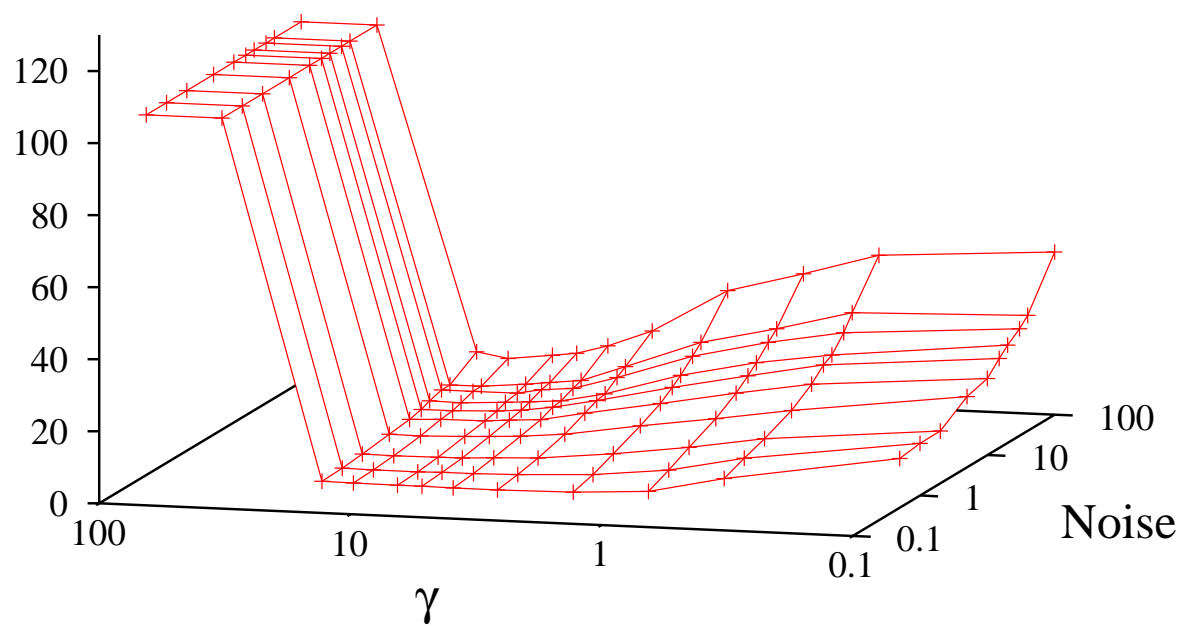

Figure 3.15: Average RMEs as a function of different $\sigma$ and $\gamma$ values.

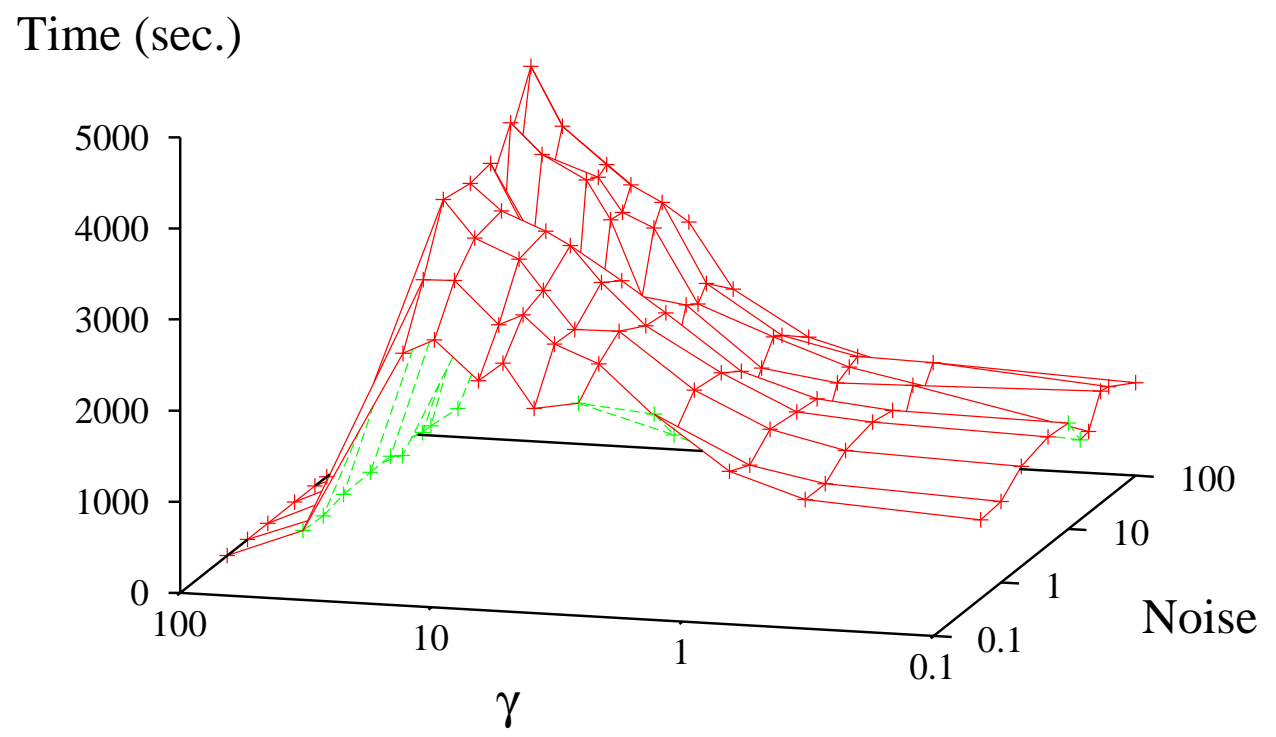

Figure 3.16: Average run-times in the case of different noise and $\gamma$ values. 
The conclusion can again be drawn that a big amount of noise can be offset by choosing a bigger $\gamma$. However, it must be added that a bigger $\gamma$ is inclined to merge close objects that are distinct in the average reconstruction in Figure A.3(d).

Even though the projections are affected by big amounts of noise ( $\sigma=20,40$ say), it is quite apparent that the technique provides improved results with the assumption of smoothness, whose property can also be exploited for the reconstruction of physical projections.

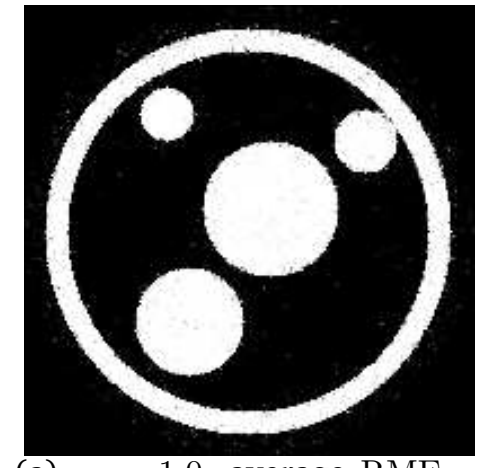

(a) $\gamma=1.0$, average $\mathrm{RME}=$ 4.0558 .

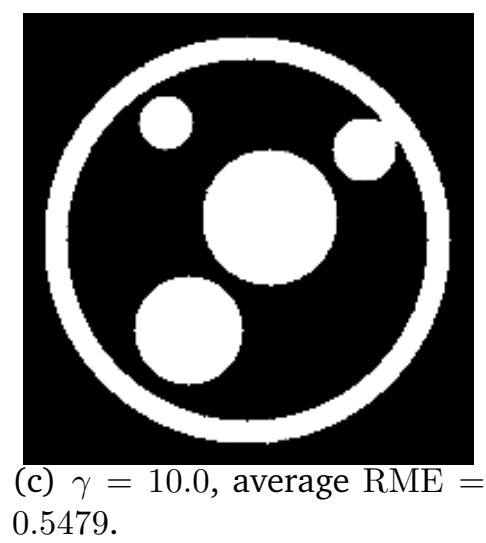

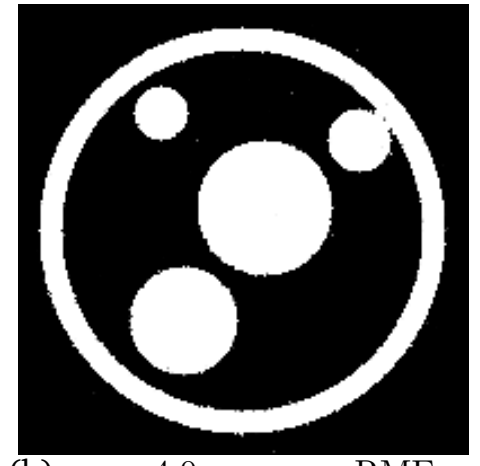

(b) $\gamma=4.0$, average $\mathrm{RME}=$ 0.9683 .

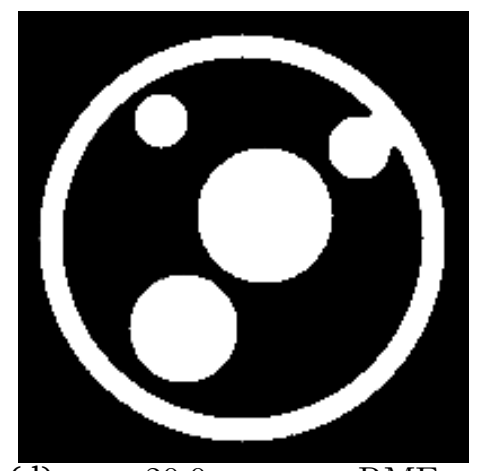

(d) $\gamma=20.0$, average RME $=$ 0.6829 .

Figure 3.17: Average reconstruction results for circles having $\sigma=1$ noisy projections with the pixel-based method (16 projections, 400 measurements/projection).

\subsection{Multi-level reconstruction}

After discussing the binary phantom results, let us turn to the results obtained for multi-level images $[17,43]$. To enable the method to reconstruct objects containing three or more (3-5 say) materials, it was necessary to

- extend the reconstruction technique to the case of multi-level images,

- create a 3-level phantom,

- supply a new formula to characterize the goodness of 3-level results. 
For the 3-level extension, the first perturbation strategy described in Section 2.3.2 was applied, where the modification rule was the random choice of a value from the set of possible intensity levels. In this way, the fully stochastic nature of the technique could be retained. The second strategy, where the intensity levels were always replaced with the neighbouring intensity values, quite often got stuck in local minima and usually underperformed the fully stochastic version in comparative tests.

In the simulation tests the 3-level phantom image depicted in Figure 3.18(a) was applied, which was constructed by replacing a white disk in Figure 3.1(a) with its grey version. The new disk had an intensity of 0.5 , so the discrete set of intensity levels was $\{0,0.5,1\}$. Its $270^{\circ}$ projection is shown in Figure 3.18(b) for the sake of comparison with the matching binary projection in Figure 2.7(b).

Lastly, the formula used to measure the goodness of multi-level reconstructions was defined in Eq. 3.4. This indicator was also used in the 3-level simulations.

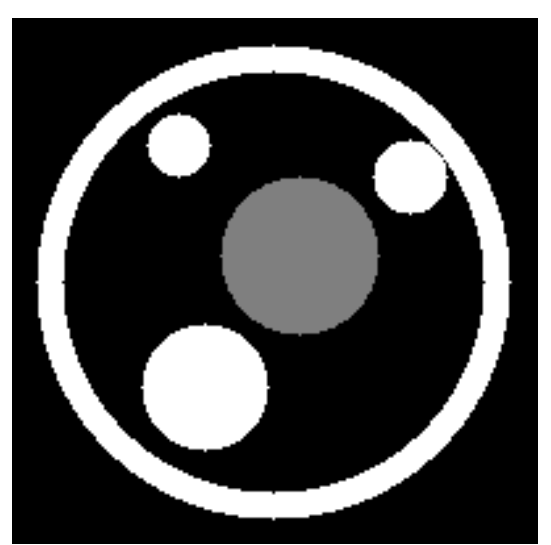

(a) A 3-level phantom image used for simulation studies.

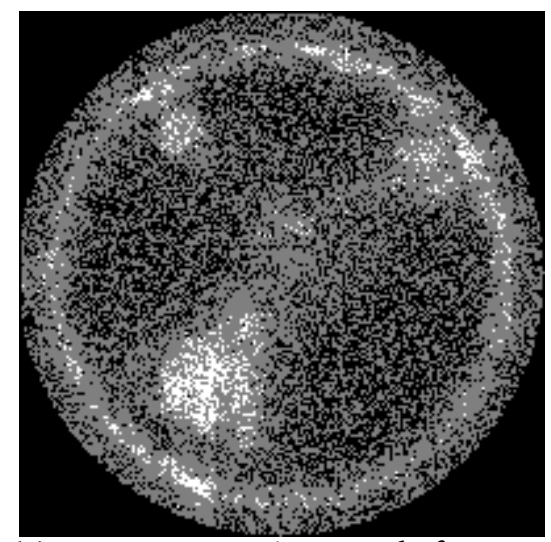

(c) A reconstruction result from 12 noiseless projections, 400 measurements/projection having $\gamma=0$.

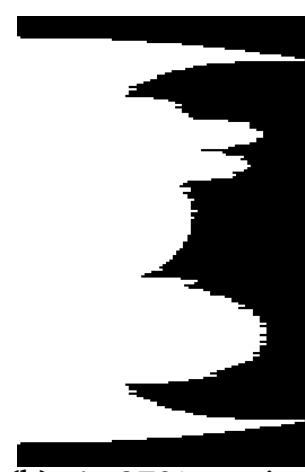

(b) A $270^{\circ}$ projection of the object in (a).

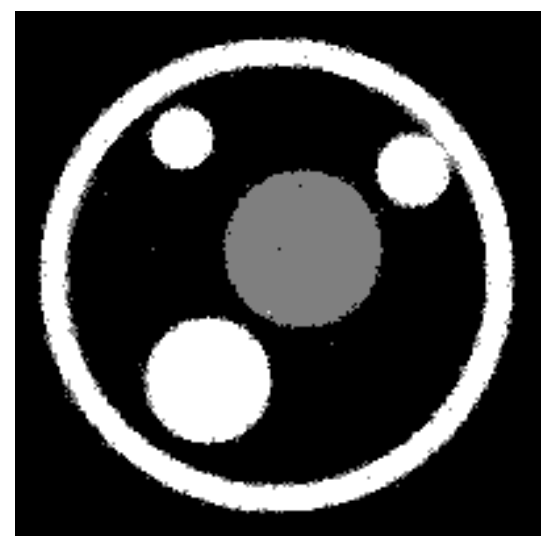

(d) A reconstruction result from 12 noiseless projections, 400 measurements/projection having $\gamma=1.0$.

Figure 3.18: The 3-level phantom image with one of its projections used for multi-level simulations and also two noiseless reconstructions. 


\subsubsection{Noiseless simulation results}

3-level reconstructions from noiseless projections gave remarkably worse results (see Figure 3.18(c)) than the binary noiseless simulations using the same number of projections. The reason for the poor quality might be the presence of an enhanced number of switching components in the case of multi-level images. However, a visually bad reconstruction cannot necessarily be regarded as a bad result if the objective value approaches zero. In this case an irrelevant bad result is one of the possible solutions, whose number also grew due to the increased number of switching components. The usual way to reduce the number of possible results is by incorporating some a priori into the objective functional to allow the technique to select the best one, i.e. the one with the desired properties.

Another obvious way to improve the image reconstructions would have been to use more projections. However, as the basic idea was to keep the number of projections low, regularization was applied. Figures 3.18(d) and 3.19(a)-(e) show how the results improve when the penalty term is turned on (i.e. setting $\gamma>0$ ) in the objective. As seen, the cylinder and disks became almost homogeneous, but grey rings appeared along the borders of black and white regions. This feature of the technique is more evident for bigger values of $\gamma$, where the smoothing term eventually overrides the first term of the objective and produces reconstructions containing grey objects only.

\subsubsection{Noisy simulation results}

3-level noisy tests were performed with the same parameter values as those presented in Section 3.4.1. The results have been plotted in figures B.1 and B.2 with $\sigma=5$ and $\sigma=30$. Here the regularization term had to handle both the noise effect and the large number of switching components. Accordingly, the multi-level noisy tests gave even worse reconstructions than the noiseless multi-level ones, which is also seen in the plot in Figure 3.20. It tells us that the average $\mathrm{RME}^{\mathrm{m}}$, as a function of $\gamma$ and noise, had a minimum around $\gamma=2$ over the range investigated, and any changes in the coefficient entails greater average relative mean errors. An overly small $\gamma$ cannot remove all the noise from the image and introduces noisy reconstructions, while a bigger one eliminates the image details and results in spurious extensive homogeneous regions, but both issues commonly increase the difference between the original and reconstructed images. As regards the noise components in the projections, only a moderate increase can be observed in the average $\mathrm{RME}^{\mathrm{m}}$, where more noise was added to the input data. That is, most of the pixels in the reconstructed images were properly determined, and just a few pixels were misplaced.

Next, looking at Figure 3.21, the average run-times display an outstanding stability against the various parameter configurations, apart from the fact that the technique became CPU costly at the same time. Even the shortest reconstructions took about 1000 seconds, but the best results required up to 2200 seconds. Although there is no information on the exact shape of the objective, the latter two plots suggests a deep multi-dimensional V-shaped objective around $\gamma=2$. 


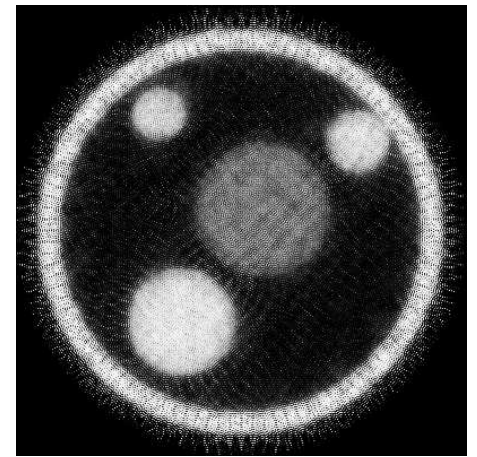

(a) $\gamma=0.0$, average $\mathrm{RME}^{\mathrm{m}}=$ 55.4379 .

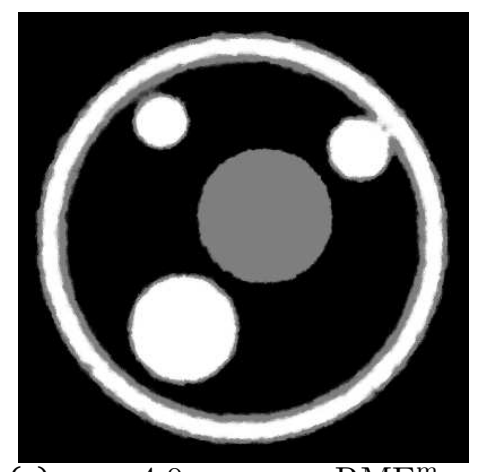

(c) $\gamma=4.0$, average $\mathrm{RME}^{\mathrm{m}}=$ 15.1434 .

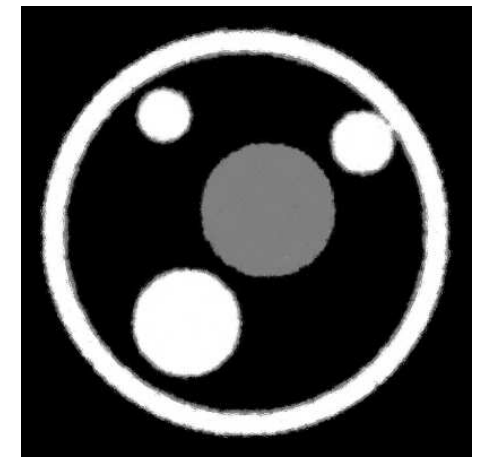

(b) $\gamma=2.0$, average $\mathrm{RME}^{\mathrm{m}}=$ 8.6620 .

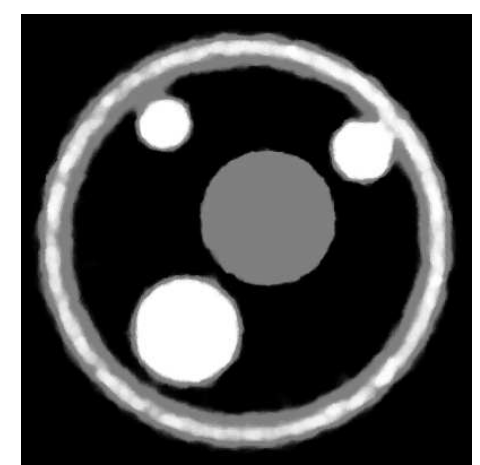

(d) $\gamma=6.0$, average $\mathrm{RME}^{\mathrm{m}}=$ 28.6172 .

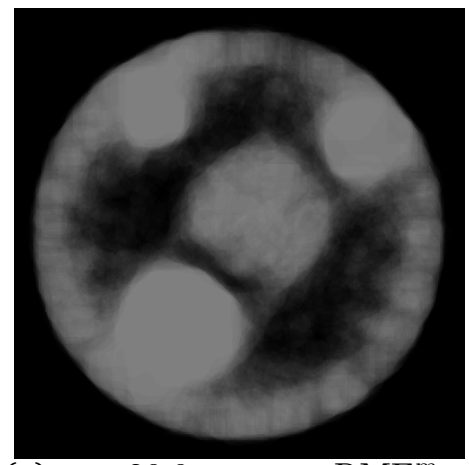

(e) $\gamma=20.0$, average $\mathrm{RME}^{\mathrm{m}}=$ 86.0685 .

Figure 3.19: Average reconstruction results of circles with noiseless projections got by using the pixel-based method (16 projections, 400 measurements/projection). 
RME (\%)

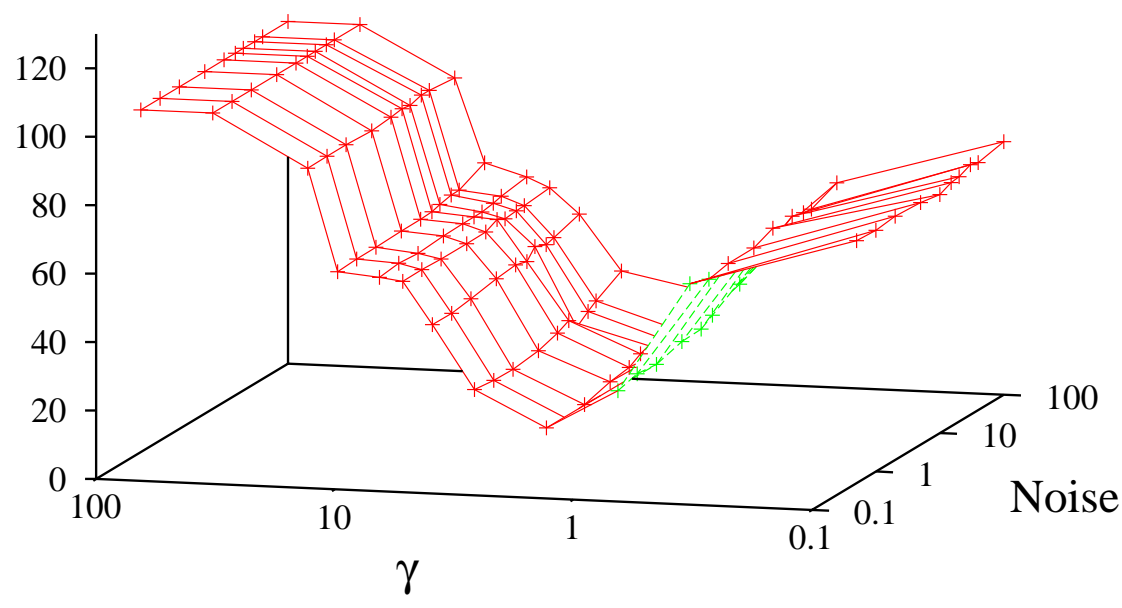

Figure 3.20: Depiction of average $\mathrm{RME}^{\mathrm{m}} \mathrm{s}$ against different noise and $\gamma$ values using logscaled $\gamma$ and noise axes.

Time (sec.)

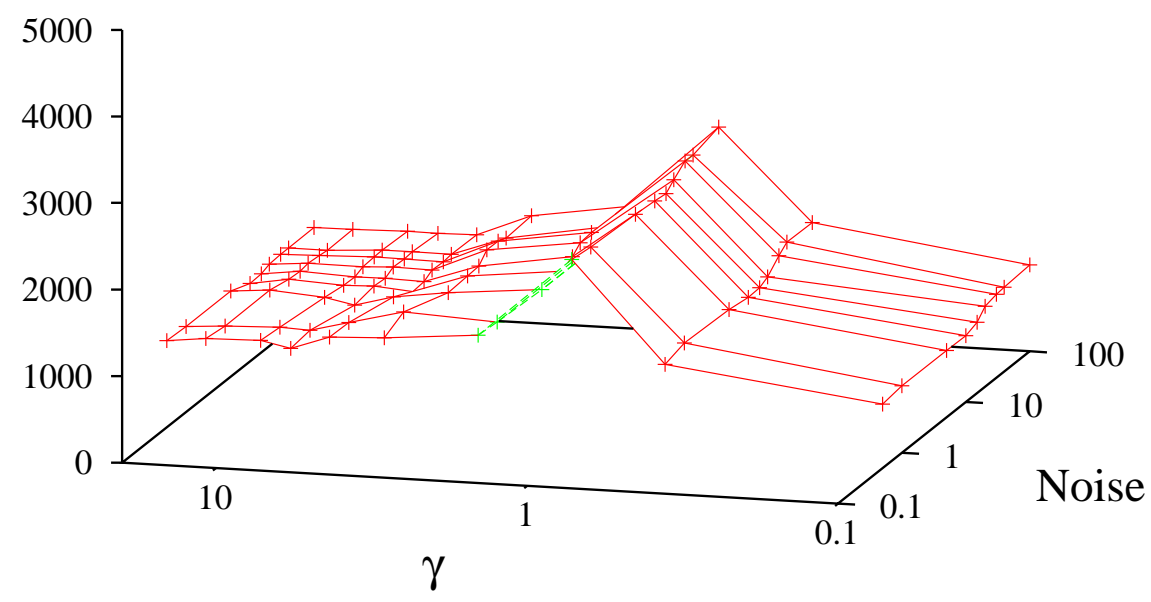

Figure 3.21: Depiction of average run-times against different noise and $\gamma$ values using $\log$-scaled $\gamma$ and noise axes. 


\subsection{Summary}

In this chapter, the simulation system and its three components developed to test the reconstruction technique in a simulation environment was introduced. The author also outlined the initial range of the annealing parameters, a suitable annealing schedule, and presented the simulation environment as well as the software phantoms used for the simulation tests.

After the preparatory steps, the behaviour of the method by simulating the ideal and simplest conditions was investigated, where the projections were noiseless and the object to be reconstructed was a binary image. Here the author examined how the pixel-based technique performed when its parameters were changed within some reasonable range. In addition, it was also tested whether the method displayed any sensitivity to the geometrical structure of the object to be reconstructed. It was clearly shown that the method was quite sensitive to the geometrical properties of the objects and that the most important parameter was the cooling factor from a reconstruction quality point of view.

In order to mimic real-life physical conditions, a statistical noise model was presented, which was developed and incorporated into the simulation environment to distort the projections by additive Gaussian noise. To improve the corrupted reconstructions, the objective functional was supplemented by a regularization term, which incorporated a priori information, preferring the homogeneous regions to non-homogeneous areas. The benefits of regularization was examined by studying the binary reconstruction results.

Next, the results produced by the reconstructions of a 3-level software phantom were presented, where it was observed that the regularization term can also be applied to improve the results of a multi-level pixel-based task. 


\section{Chapter 4}

\section{Physical background and pre-processing}

This chapter outlines the projection acquisition apparatus and how the real projections were obtained. We also describe the distorting effects arising from the physical properties of the imaging system. As these distortions can cause serious degradation in the reconstruction results, it is necessary to correct them as best one can. Hence a feasible sequence of correction steps was developed, whose benefits are demonstrated via classical FBP reconstructions at the end of the chapter.

The results of this chapter were published in $[11,52]$.

\subsection{Projection acquisition}

In order to image an object, several kinds of radiation sources (gamma-ray, neutron, $\mathrm{X}$-ray, etc.) can be used, but the set-up of the apparatus of radiography presented in Figure 4.1 is quite common and is widely used nowadays. The object to be investigated is placed on a rotating table. The table can be rotated by a PC-controlled stepper motor, thus letting the beams pass through the object in different directions. The beams attenuated by the object strike a scintillator, which transforms the detected radiation into visible light detected by a CCD camera. Since the camera can be damaged by direct exposure to radiation, an optical mirror system conveys the light from the scintillator to the CCD camera. The images taken by the camera are stored temporarily by the camera controller, and then a dedicated PC reads out the raw image data from this storage. In older systems the CCD camera is often substituted by a removable and reusable detector plane that stores the image until it is inserted in a special device, which retrieves the information and then erases the content. A more detailed description of the imaging apparatus can be found in [11].

As mentioned in Section 2.2.2, it will be assumed that the radiation source emits parallel beams. This assumption is not unrealistic since when the object being investigated is far enough from the source, the transmitted beams will be almost parallel, and no significant geometric distortion will be introduced into the projections. 


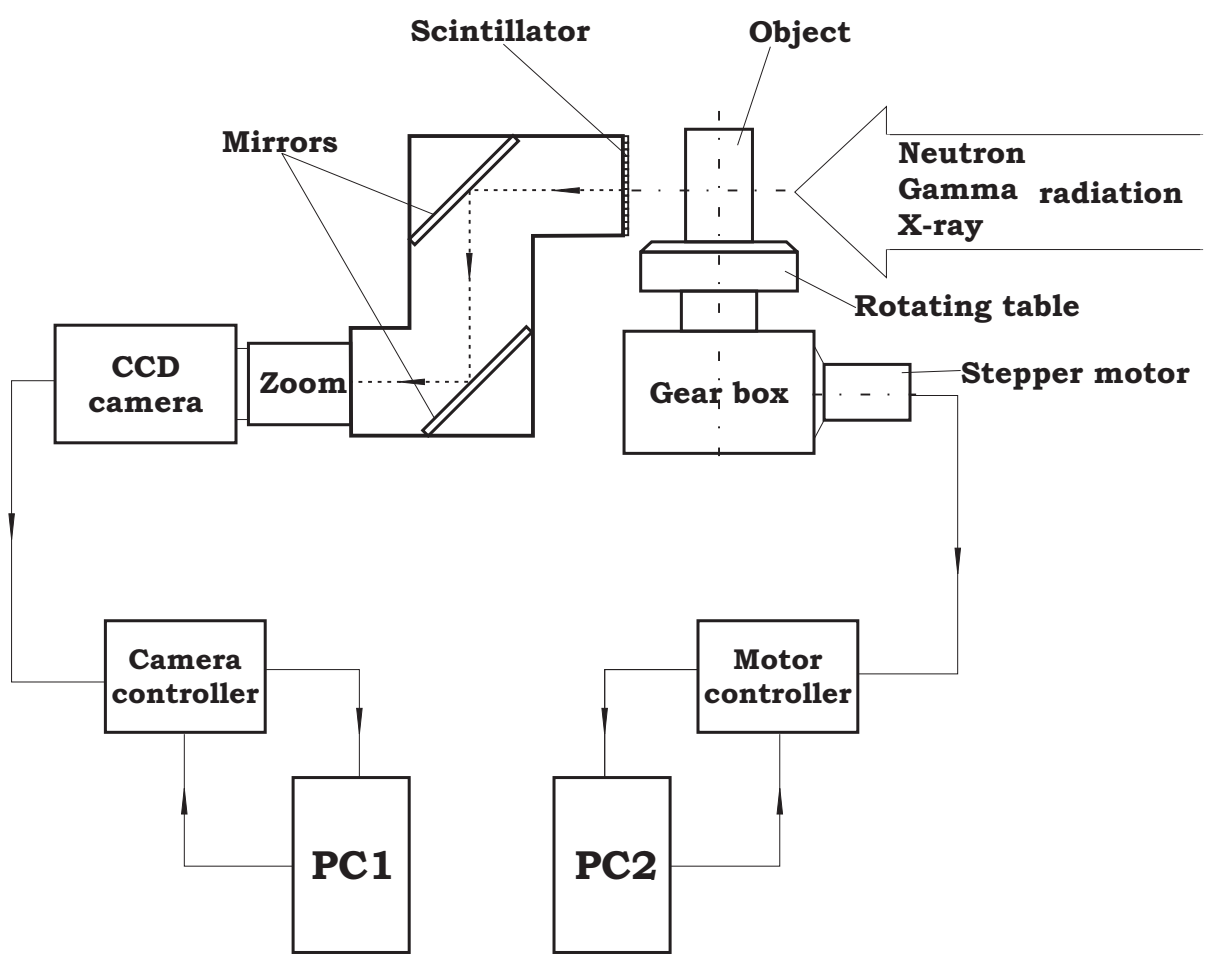

Figure 4.1: Imaging apparatus for collecting projections.

\subsection{Radiation sources}

Now we will discuss three kinds of radiation sources that are widely used in physical non-destructive examinations, namely X-ray, neutron, and gamma radiation. They mainly differ in the installation of radiation source, absorption attributes of the various materials, scattering, and the CCD camera or detector plane (so-called converter) used. Their differences are reflected by the projections of the three reference cylinders shown in Figure 4.2. The cylinders were constructed from various materials, but had the same geometry. Due to the different distances between the radiation source, object, and detector, even the sizes of the projected objects appeared to be different.

\subsubsection{X-ray radiation}

X-ray radiation was discovered by the German physicist Wilhelm Conrad Röntgen in 1895, and this achievement earned him the first Nobel prize in Physics in 1901.

The basic way of producing X-rays is by accelerating electrons in order to hit a target and knock out electrons from the inner shell of atoms. However, this electron vacancy will be filled up by an electron from a higher shell and an X-ray photon is emitted at the same time.

In the last few decades a range of applications for X-rays have appeared, such as in medicine, material examinations, crystallography and astronomy. Thanks to technological improvements, an X-ray generator is now of portable size, even if 
(usually lead) shielding is included. More literature on the topic of X-ray imaging can be found in [39].

From a tomographic aspect, some important properties of X-rays should be emphasized. Materials of low density (air, water, etc.) transmit the X-ray photons without attenuation, but the higher the density of the material (e.g. lead), the more radiation is absorbed. The scattering can be collimated, the noise level can be controlled, but mono-energy radiation is difficult and expensive to produce. An image taken using an X-ray source is shown in Figure 4.2(a).

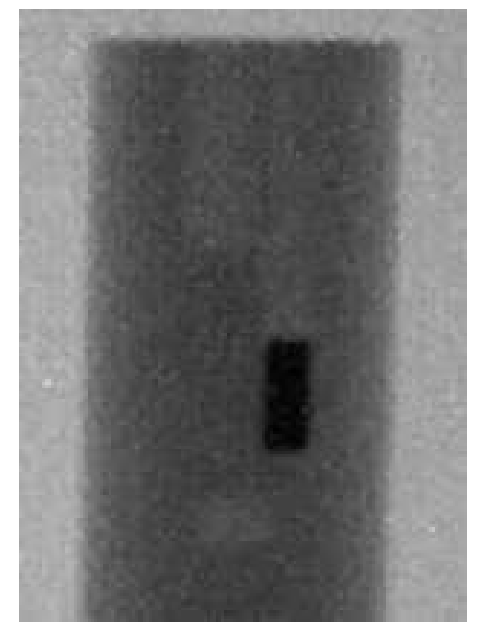

(a) A projection of a Plexiglas cylinder taken using X-ray radiation.

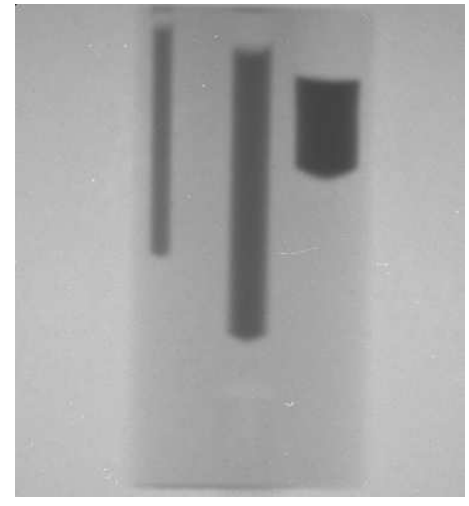

(b) A projection of an aluminum cylinder taken using neutron radiation.

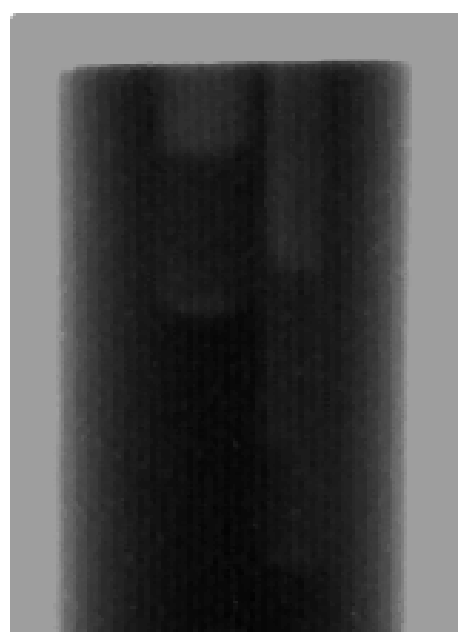

(c) A projection of an iron cylinder taken using gammaray radiation.

Figure 4.2: Projections of cylinders with bores taken using different radiation sources.

\subsubsection{Neutron radiation}

Neutron radiation is an ionizing radiation consisting of free neutrons, which are emitted during nuclear reactions. Since atomic fission (and fusion) can only be produced by an atomic reactor, the radiation source is immobile, and neither the radiation outlet can be moved or redirected. Therefore, the installation of the acquisition systems must be adapted to the reactor facility. Next, the robust shielding (a set of thick concrete wall modules) provides restricted opportunities from an object size and a rotation point of view. Despite the severe conditions, collimation (e.g. with gadolinium) is possible, but it is quite expensive; moreover, the device can be up to several metres long.

Neutron and X-ray radiation differ in many respects. The most important one is that neutron radiation is absorbed by light nuclei (e.g. hydrogen-rich materials like water, paraffin wax, or concrete, where a considerable amount of water molecules is chemically bound to the cement), but transmitted in an environment of heavier nuclei like metals (iron, say).

Since the human body is mostly made up water, neutron radiation can seriously damage the cells and DNA, hence this prohibits its application in medical treatment. 
However, it can be used for industrial objects containing materials of high as well as low density, like water, acetone, and metal, as shown in Figure 4.2(b).

\subsubsection{Gamma-ray radiation}

Gamma-ray radiation is a light emission of high frequency (very short wavelengths) emitted during electron-positron annihilation or radioactive decay. Since it is not stopped by the skin, but penetrates the body and interacts with the living cells, it can cause serious deformations in the genetic DNA. This fact gives rise to the necessity of shielding in gamma-ray radiation experiments, which has to be constructed from a large amount of high density materials. Thus its mobility is not feasible.

Since this radiation is modestly attenuated by materials of high density, it is of primary importance in non-destructive metal examinations. However, due to the complex equipment, its employment is quite expensive. A gamma projection image is shown in Figure 4.2(c).

\subsection{The acquired projection}

In non-destructive testing (NDT) the objects are imaged by rays radiated by external radiation sources. The rays passing through the object are then partially absorbed, while the unabsorbed particles strike the detector bins. The numbers of impacting particles (counted by the detector bins) give the intensity values in the projection images.

The connection between the initial and transmitted (unabsorbed) intensities, $I_{S}$ and $I_{D}$, respectively, can be expressed as a function that depends on the absorption (or attenuation) coefficient $\mu$ of the object. Namely,

$$
I_{D}=I_{D}(s, \vartheta)=I_{S} \cdot e^{-\int_{S}^{D} \mu(u) d u},
$$

where $S$ and $D$ denote the source and the detector. This equation is a basic relation in transmission tomography, and it is also known as Beer's law. (See Figure 4.3.)

It can be seen that the exponent contains the integral in Eq. 2.1 for a fixed $s$ and $\vartheta$. In practice, the task is to determine $\mu$ by making the assumption that $I_{S}$ and $I_{D}$ are measurable. The value of $\mu$ is immediately implied by the logarithmic transformation of Eq. 4.1, and it has the form

$$
\int_{S}^{D} \mu(u) d u=\ln \left(I_{S} / I_{D}\right) .
$$

Several inferences can be drawn from this equation. The left hand side of the equation is zero if and only if $I_{S}=I_{D}$, meaning that there is no attenuation when the beam is being transmitted. When the detected intensity is zero $\left(I_{D}=0\right)$, then no attenuation can be determined, since the fraction on the right hand side cannot be interpreted. The best that can be done is to assume an infinitely large absorption 


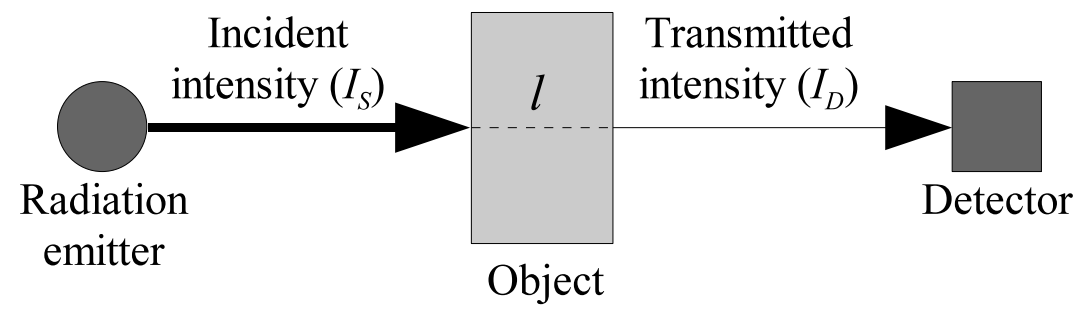

Figure 4.3: Scheme used to illustrate Beer's law and the phenomenon of radiation attenuation. $I_{S}$ is the intensity emitted by the radiation source, $I_{D}$ is the intensity measured by the detector, and $l$ is the length of the line segment intersected by the projection beam and the homogeneous object.

under such circumstances. In real circumstances, the zero measurements are usually caused by an overly short exposure time, which can be eliminated by choosing longer acquisition periods for the projections.

Another problem arises when the object is made of materials that have relatively big and small absorption coefficients. If a material has a small $\mu$ and the exposure time is long, the measured value can be nearly equal to $I_{S}$, meaning that $\mu=0$. In contrast, if a material has a big $\mu$, a short exposure time results in $I_{D}=0$, giving an infinite absorption coefficient. In these situations physicists have to decide whether the object components with the low or high absorption coefficient are more important, and the exposure time should be set accordingly. However, the exposure period must not be too short as it results in a low signal-to-noise ratio and yields poor projections. Lastly, the object being projected may accumulate some of the radiation, and return it after a short latency. It can produce false detected intensity values, and even lead to the case of $I_{D} \geq I_{S}$.

Since neither subsampling nor oversampling of the projection images improves the reconstruction result, it is expedient to assign a pixel to each detector bin (and perform the reconstruction as it is). That is, each pixel value in the projection image represents the value measured by the corresponding detector bin of the acquisition apparatus.

\subsection{Imaging artifacts}

Physically measured projections are usually unsuitable for an immediate reconstruction due to the effects the images are distorted by. One of the problems might be when the intensity of rays or the sensitivity of camera changes during the acquisition period. (Cold or warm camera electronics can produce such effects, for instance.) Then brighter or darker projections may be acquired. Such images can be reconstructed just with artifacts.

Some of the distortions are due to the properties of the image acquisition system. For example, if the detector system is not uniformly sensitive in the whole field of 
view of projections, certain areas may be brighter, while others may be darker. This non-uniformity case may produce ring artifacts in the image reconstructions.

Another source of artifacts might be when the projections are taken not exactly as they should be in their necessary positions. For example, when the projection of the axis of rotation is not exactly in the centreline of the projection images. This can occur when the object, due to its size, cannot be placed on a rotating table, but is rotated manually, say. This centre of rotation problem may blur the contours in the reconstructed images.

In practice, it is common for the projection images to randomly contain white isolated points owing to some problems with the detector system. For example, some pixels may be burnt out in the detector plane.

Since the reconstruction is a distortion amplifying procedure, these corrupting effects should be corrected before, during, or after the reconstruction. This study deals only with the corrections performed before a reconstruction. To this end, a set of pre-processing steps were developed, which are presented in the following sections.

Some distortions are beyond the scope of this thesis. For instance, serious distortions can be caused by the so-called beam hardening attribution of polychromatic radiation; that is, when the beams consist of particles with a broad energy spectrum. The name of this phenomenon comes from the fact that the beams passing through an object become 'harder' (the mean energy increases) because the lowenergy particles are absorbed more rapidly, leaving behind the high-energy ones. This effect was left uncorrected.

Another type of corruption is the partial volume effect, when a single pixel (or voxel in 3-dimensional space) contains a mixture of materials. When the effect is caused by the inhomogeneity of the constituent materials, the homogeneity condition of DT is violated and pure discrete tomographic techniques cannot be applied. If the materials are homogeneous, this distortion can still appear on the region borders, and usually means that the border is replaced by an intermediary intensity of neighbouring regions.

Lastly, there is the distortion of metallic artifacts, which is common problem in medical X-ray imaging, but it could not be identified in any of the physical measurements studied here.

\subsection{Pre-processing steps}

The corrupting effects in medical and industrial imaging are sometimes quite different, hence the correction methods used in medical image processing are not universally applicable or not sufficient in industrial tomography. Now we present the distortions encountered in the physically acquired images, the corresponding correction methods worked out to eliminate (or at least diminish) the corruptions, and the logarithmic transformation that was indispensable when DT methods were applied on real measurement data.

1. Cropping. The projection of the object being investigated often covers just a 
small part of the whole acquired image, so the relevant part is selected and cropped from all projections. These cropped projection images of a smaller size are used in the later pre-processing steps and reconstruction. The reconstruction from cropped projections requires less memory and computational time; in addition, the smaller (probably distorted) the background area involved in the reconstruction, the better the reconstruction quality can be expected.

In Figure 4.4, an original $768 \times 572 \mathrm{X}$-ray projection of a VIDICON tube can be seen. It is obvious that the shielding (black regions) on the left and right hand sides harmed the reconstruction and had to be cut down; moreover, most of the background was eliminated as well. After, a $241 \times 572$ portion was selected, which contained the object for each projection. (This is the white box in Figure 4.4.)
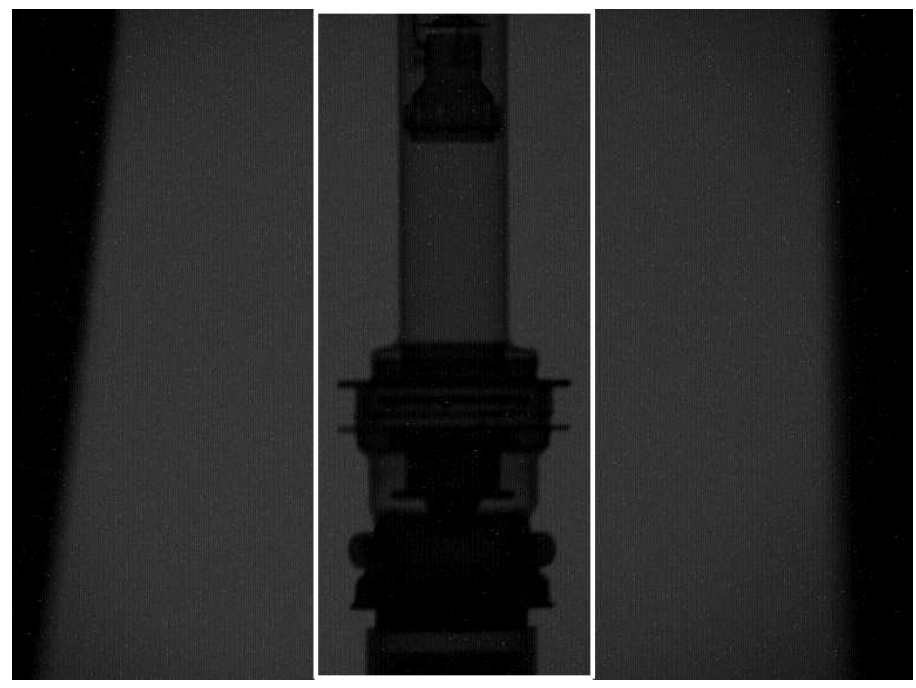

Figure 4.4: One of the X-ray projections of the VIDICON tube (height $\approx 18 \mathrm{~cm}$, width $\approx 3 \mathrm{~cm}$ ). The white lines denote the cropped area.

2. Motion correction. It can also happen that the settings of the projection images were not perfect and that some of the images were not taken from the right position. A consequence might be that the images are the rotated or translated versions of the correct ones. In general, such distortions cannot be corrected, unless we know (or can estimate) the parameters of the motions that occurred during the projection acquisition. To estimate these parameters some information can be exploited like object symmetry, external or internal markers, opposite projections, and projections from an acquisition using a phantom object of a known geometry.

Actually, two new pre-processing methods were employed in the system. Both correction methods can be divided into two sub-steps:

(a) Estimating the parameter values needed for the correction transformation. 
(b) Carrying out the correction transformation to obtain a new, corrected projection sequence that will be utilized in later steps.

The difference between the two correction methods lies in the choice of transformation:

(a) The first method is suitable when opposite projections are available, and the positioning errors can be modelled such that the projections of the rotation axis are translated horizontally in the projection images (along a sine curve, say). In this case the necessary transformation is the horizontal translation of each projection image, whose parameter values can be determined by overlapping the flipped image and its opposite version ('centre of rotation correction' [52]).

(b) The second method presumes that the projections of the object are very similar (e.g. the projections of a tube from the directions perpendicular to the tube's axis). By applying a suitable rigid registration on all the projections to a selected reference image, one can find the correct projection settings. The registration technique applied here was Tanacs's rigid method published in [69].

3. Homogeneity correction. Sometimes the detector plane is not uniformly sensitive in the whole field of view. This problem can be lessened if an 'empty' image is available. The empty image is acquired by imaging a homogeneous radiation flux. If the detector system is uniformly sensitive, then this image is almost constant. Otherwise, the empty image reveals how much correction (multiplication) is necessary, pixel by pixel in each projection, in order to obtain more constant images. The correction can be described mathematically in the following way. For each pixel $i$ of all $P_{\vartheta}$ projections,

$$
r_{\vartheta, i}=p_{\vartheta, i} \cdot \frac{1}{p_{e m p t y, i}}
$$

where $p_{\vartheta, i}, p_{\text {empty,i }}$, and $r_{\vartheta, i}$ denote the intensity of the $i$ th pixel in the original $\vartheta$ projection $\left(P_{\vartheta}\right)$, in the empty image $\left(P_{\text {empty }}\right)$, and in the corrected $\vartheta$ projection $\left(R_{\vartheta}\right)$, respectively.

An example of this distortion can be seen in the empty image shown in Figure 4.5. Moreover, another typical effect can be observed here, when the central part of the ROI is lighter while the periphery is darker. It was caused by the flux growing weaker from the radiation centreline towards the periphery, which was also corrected by the homogeneity correction.

4. Intensity correction. It might happen that the total intensities of the projection images vary during the acquisition period. The reason could be variations in the neutron flux or the electronic properties of the camera, as described in Section 4.3. When this occurs each pixel $j$ in each image $P_{\vartheta_{i}}(i=1, \ldots, m)$ should be multiplied by a suitable positive real constant $C_{i}$ such that 


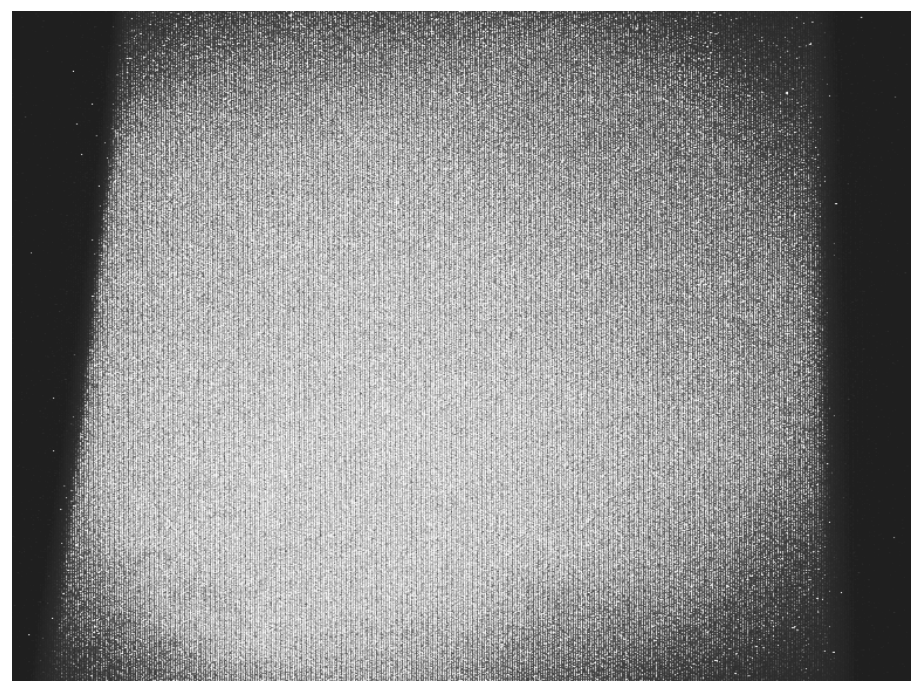

Figure 4.5: The equalized empty image for the projection in Figure 4.4.

$$
C_{i} \sum_{j=1}^{d} p_{\vartheta_{i}, j} \approx K
$$

where $d$ is the number of pixels in a projection, and $K$ is a positive real denoting the desired total intensity. In other words, the total intensity values will be roughly the same in the corrected projections. For instance, for an arbitrary fixed $\tilde{i} \in\{1, \ldots, m\}$ reference projection, $K$ can be calculated as

$$
K=\sum_{j=1}^{d} p_{\vartheta_{\tilde{i}}, j}
$$

and $C_{i}$ can be defined by

$$
C_{i}=\frac{K}{\sum_{j=1}^{d} p_{\vartheta_{i}, j}}
$$

for all $i=1, \ldots, m$. The author applied this form of intensity correction in the experiments.

After this step the flickering, which is often visible when playing the projection sequence like a movie, diminishes. This correction step can be divided into two sub-steps:

(a) The calculation of correction factors for each projection.

(b) Performing the correction method, which yields a new corrected projection sequence for the subsequent correction steps and reconstruction. 
5. Isolated specks. The tomographic projections often contain white pixels (as shown in Figure 4.8(b)), which appear as isolated points having a very different intensity value compared with its neighbourhood, and can give rise to strong white lines in the reconstructions. In order to eliminate this kind of problem in the projections, we performed thresholded median filtering. For each pixel $i$ of each $P_{\vartheta}$ projection

$$
r_{\vartheta, i}= \begin{cases}p_{\vartheta, i} & \text { if }\left|p_{\vartheta, i}-\operatorname{med}\left(\operatorname{NRH}\left(P_{\vartheta}, i, n\right)\right)\right| \leq \text { thr } \\ \operatorname{med}\left(\operatorname{NRH}\left(P_{\vartheta}, i, n\right)\right) & \text { otherwise }\end{cases}
$$

where $r_{\vartheta, i}$ is the intensity of the $i$ th pixel in the corrected image $R_{\vartheta}$, med(.) is the median operator, thr is a suitable threshold constant, and $\operatorname{NRH}\left(P_{\vartheta}, i, n\right)$ is a set which contains the intensity values of the $n$-neighbourhood pixels of $i$ in the image $P_{\vartheta}$. Such an $n$-neighbourhood for $n=8$ is depicted below in Figure 4.6.

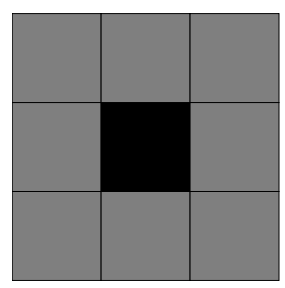

Figure 4.6: The 8-neighbourhood of the black pixel is represented by grey pixels.

6. Logarithmic transformation. In order to get the approximate values of the line integrals (i.e. instead of working with the number of impacting particles counted by the detectors), a logarithmic transformation needs to be performed on the measured intensity values, as defined in Eq. 4.2. Since this transformation is always performed on the input data, all projections after this pre-processing step are always logarithmically transformed projection images, even if not explicitly stated.

It should also be mentioned here that all the transformed images were multiplied by a suitable constant to scale up the projection vectors such that the intensity levels in the reconstructions span the interval $[0,1]$ as much as possible. These constants were estimated analytically based on the object geometry and the original projection image.

The pre-processing steps outlined above will be applied to a VIDICON tube (video camera accessory) projections in the next section.

\subsection{Pre-processing of VIDICON tube projections}

To demonstrate the benefits of pre-processing, the classical FBP was performed after each correction step using SNARK93 [7]. SNARK93 is a programming system for the continuous reconstruction of 2-dimensional images from 1-dimensional projections. 
The framework includes an entire spectrum of functionalities (like the generation of phantom objects and their projections and a quantitative comparison of reconstruction results) to support the scientific evaluation of tomographic reconstruction techniques. Although newer versions of SNARK (SNARK05 and SNARK09) were also available, we were only supplied with the early SNARK93 version.

360 projections of a VIDICON tube were taken in $1^{\circ}$ angular steps using an Xray radiation source, which included all the distortions described in the preceding section. One of its projections is depicted in Figure 4.4. The first pre-processing step involved cropping the relevant area from the original projections, because the object to be reconstructed covered only a small portion of the projections. The reconstruction gave a very poor result (Figure 4.8(d)) when no other corrections were performed in the projections. As observed, strong streaks appeared in the reconstruction, which were caused by projections of higher total intensity.

The projection sequence indicated that the rotation axis was translating horizontally during the acquisition, so the second step of pre-processing was the correction of these motions. Since an opposite image was provided for each projection, the rigid registration (described in Section 4.5) of each $\vartheta$ projection could be carried out against the horizontally flipped opposite $\left(\vartheta+180^{\circ}\right)$ projection. As the result of the analysis of registration parameters, we found that each projection had to be translated along a sine curve having a phase of $90^{\circ}$ and amplitude of 2 pixels. That is, the rotation axis moved slightly during the acquisition.

The diagram in Figure 4.7 shows the total intensities in the first 180 projections. As seen, roughly a $13 \%$ difference was observed between the maximum and minimum total intensities. The increasing tendency of the total values could be accounted for by the fact that the camera grew warmer during the acquisition process. To eliminate this problem, the intensity correction step multiplied the projections by suitable coefficients, such that the total intensity values of the corrected projections were practically constant for each projection (grey line in Figure 4.7). In this way, the intensity levels in the reconstruction may not represent the real attenuation coefficients from this point on, but the streaks vanished from the reconstructed cross-sections. One of the reconstruction results got after cropping, motion and intensity corrections can be seen in Figure 4.8(e).

When an empty projection image is available (as in the case here), homogeneity correction (Section 4.5) can be performed. Since the empty image in Figure 4.4 indicated a non-uniformly sensitive detector system, it was necessary to carry out this correction step. In Figure 4.8(c) it is readily seen that the projection became more homogeneous after the correction, and the vertical streaks, caused by the non-uniform sensitivity of the detector plane, became less obtrusive than in Figure 4.8(b). Moreover, the reconstructed cross-section in Figure 4.8(f) appeared a bit more homogeneous compared with Figure 4.8(e). This homogeneity feature is especially noticeable in the interior of the dashed circle.

Lastly, the correction of isolated specks was applied to each projection, which involved the application of a thresholded median filter (8-neighbourhood, thr $=20$ assuming a maximum intensity level of 255). In Figure 4.8(c) it is quite apparent that a major portion of the white specks were successfully eliminated from the projections. 


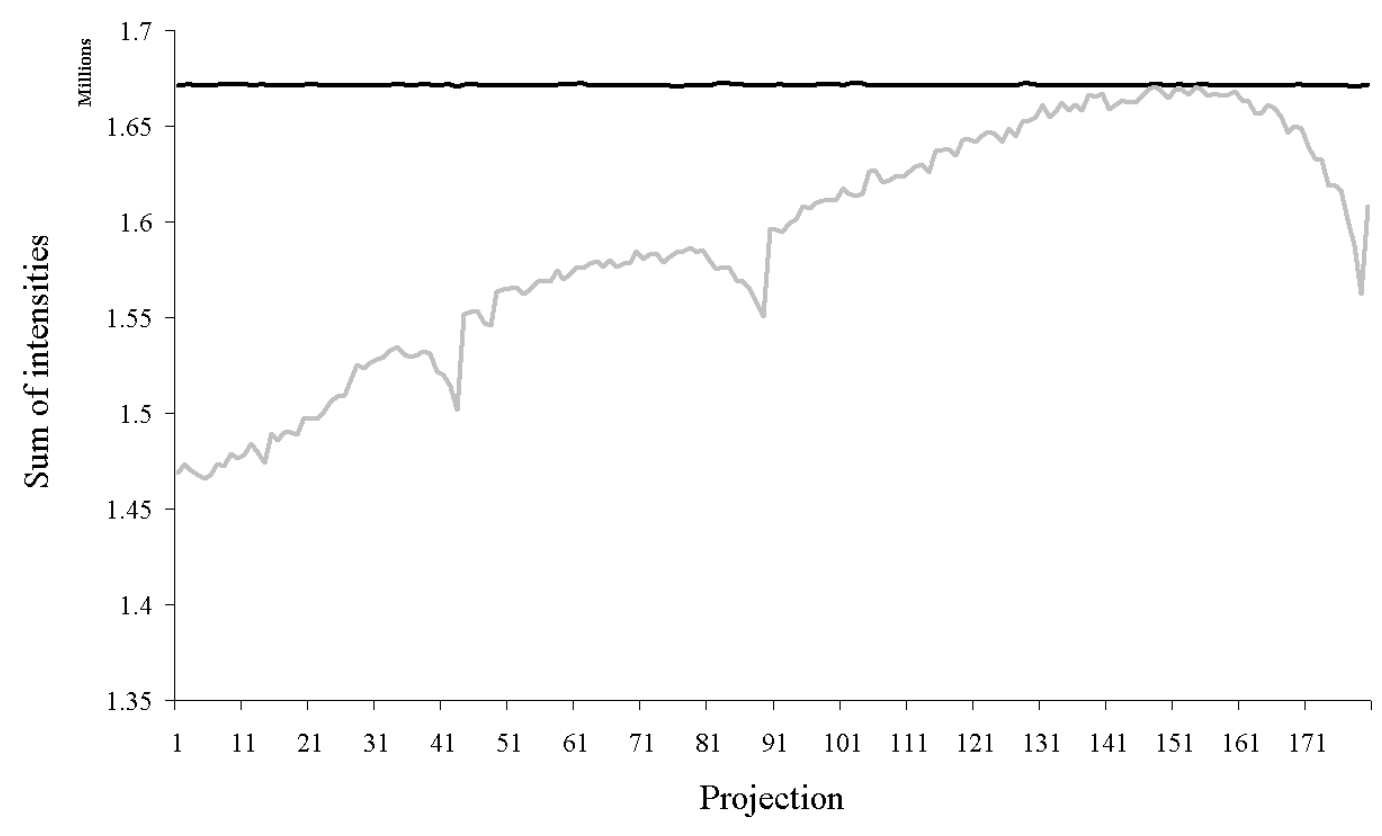

Figure 4.7: Total intensity values in the first 180 projections before (grey line) and after (black line) intensity correction.

\subsection{Summary}

This chapter introduced the physical background of the imaging procedures employed in transmission tomography, and outlined the distortions caused by the physical properties of the imaging system. As these distortions caused serious degradations in the reconstructed images, they had to be reduced as much as possible. For this purpose, the author provided a set of pre-processing steps that was able to correct the major problems identified. The benefits were demonstrated via the classical FBP reconstructions of a VIDICON tube, where the author introduced two new preprocessing steps. Intensity correction equalized the total intensities in the projections, thus correcting the varying flux rates that occurred during acquisitions, while motion correction was applied when the projections were the translated and/or rotated versions of the expected images. 

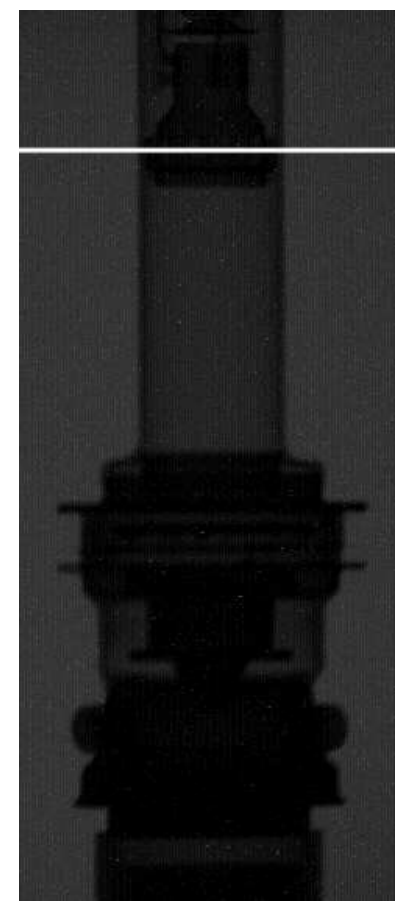

(a)

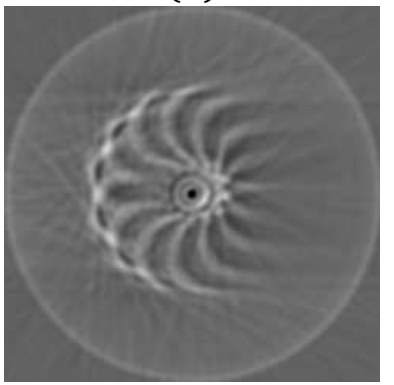

(d)
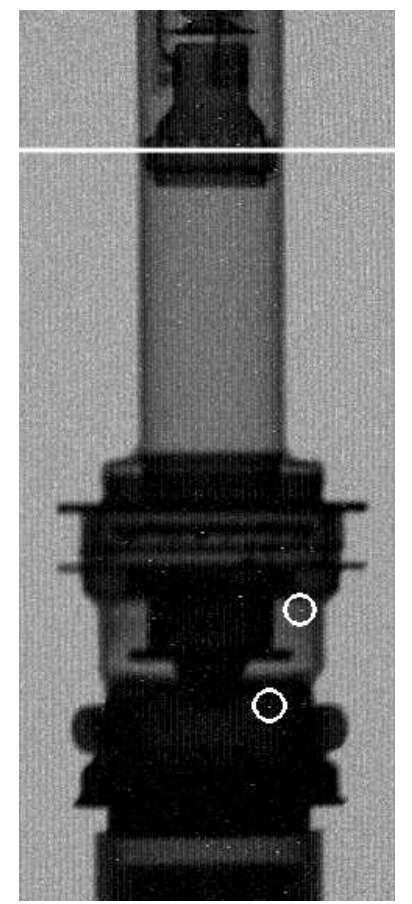

(b)

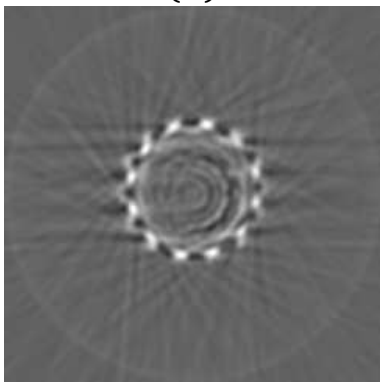

(e)

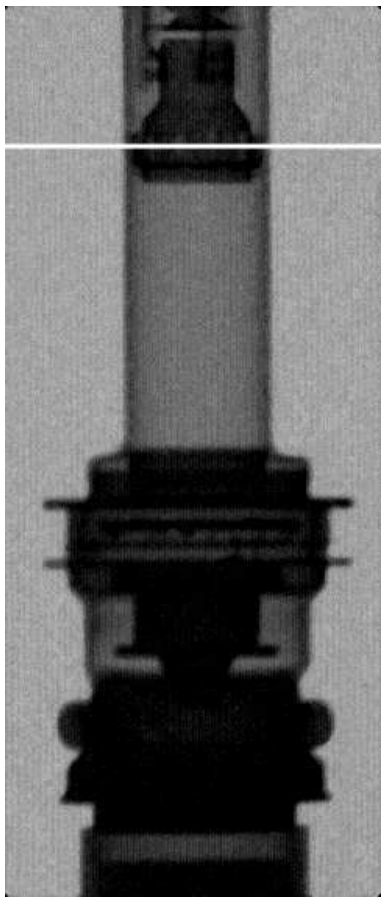

(c)

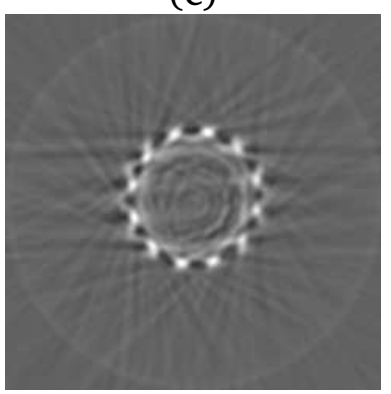

(f)

Figure 4.8: (a) One of the projections of a VIDICON tube after cropping, with size $241 \times 572$. (The white line marks the cross-section shown below.) (b) The same projection after motion and intensity corrections (the white circles mark isolated points to be corrected in the next step). (c) The same projection as in (b) after homogeneity and isolated points corrections. (d) Reconstruction of the cross-section $(241 \times 241)$ shown after cropping. (e) Reconstruction of the cross-section produced after motion and intensity corrections. (f) Reconstruction of the cross-section produced after homogeneity and isolated points corrections. The reconstruction was performed by using the software package SNARK93 (filtered back projection, cosine filter, cut-off frequency 0.5, Lagrange interpolation). 



\section{Chapter 5}

\section{Reconstructions of physical phantoms}

Here the reconstruction results of the pixel-based DT method based on the projections of different modalities are introduced by utilizing the simulation experiences outlined in Chapter 3. The author presents the tests of three physical phantoms, where the projections were acquired by applying X-ray, neutron and gamma radiation sources. For each test he used so-called reference cylinders with the geometry depicted in Figure 5.1, which were composed of different materials depending on the type of radiation applied. All the cylinders contained three bores of various diameters and depths in an asymmetric arrangement, and were filled up with different materials. That is, the projection beams pass through at least three materials; namely air, the material the cylinder was composed of, and the materials the bores were filled up with.

The author published these results in $[43,52]$.

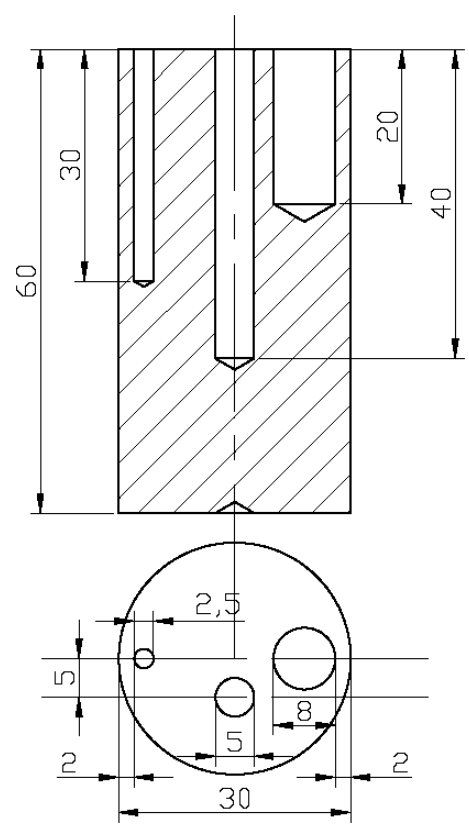

Figure 5.1: Diagram of the physical phantom object used in the experiments. 


\subsection{Reconstruction of a Plexiglas cylinder from X-ray projections}

The test object examined using an X-ray radiation source was a solid cylinder made of Plexiglas, and the lower part of the deepest hole contained an aluminum screw. One of the 72 equiangular $768 \times 572$ projections $\left(2.5^{\circ}\right.$ angular spacing $)$ and the empty image are shown in figures 5.2(a)-(b).

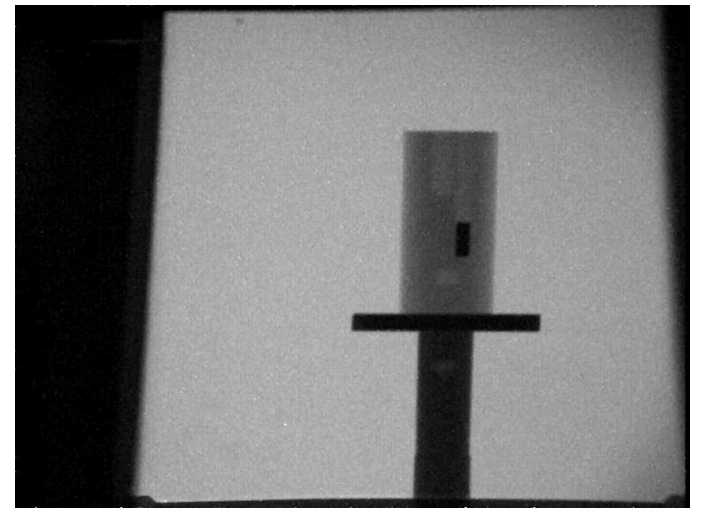

(a)

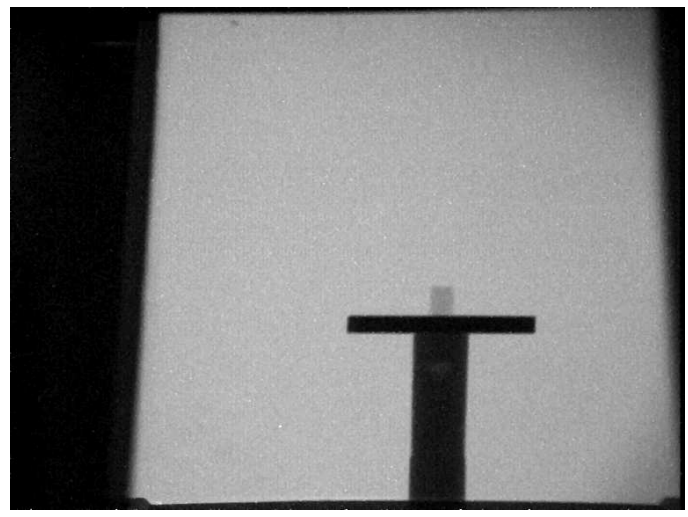

(b)

Figure 5.2: (a) One of the projections of original size. (b) The empty image just containing the rotating table.

\subsubsection{Pre-processing}

After cropping the relevant area from the projections, $155 \times 212$ images were produced, which showed strong intensity fluctuations. First, the intensity problem was taken care of. As seen in Figure 5.3, the total intensity values indicated a decreasing flux measured by the detectors, where the discrepancy between the minimal and maximal total values was over $12 \%$. This problem could be identified as a darkening image sequence while playing the projections as a movie, and the omission of this step would have produced a similar effect as that shown in Figure 4.8(d).

In order to ascertain whether homogeneity correction needed to be performed, a histogram equalization was performed against the projections and empty image (figures 5.4(c)-(d)). The lighter bottom left and darker upper right corner confirmed some inhomogeneity in the images, which was eliminated by the homogeneity correction, as shown in Figure 5.4(e).

We found that the background of the projections contained a significant amount of noise, which had a detrimental effect on the reconstruction result. This distortion was reduced by subtracting the background to remove most of the noise at least from background areas (see figures 5.4(f) and 5.5). In spite of this step, the corresponding cross-sections still remained 3-level images: the subtracted background, Plexiglas and aluminum. 


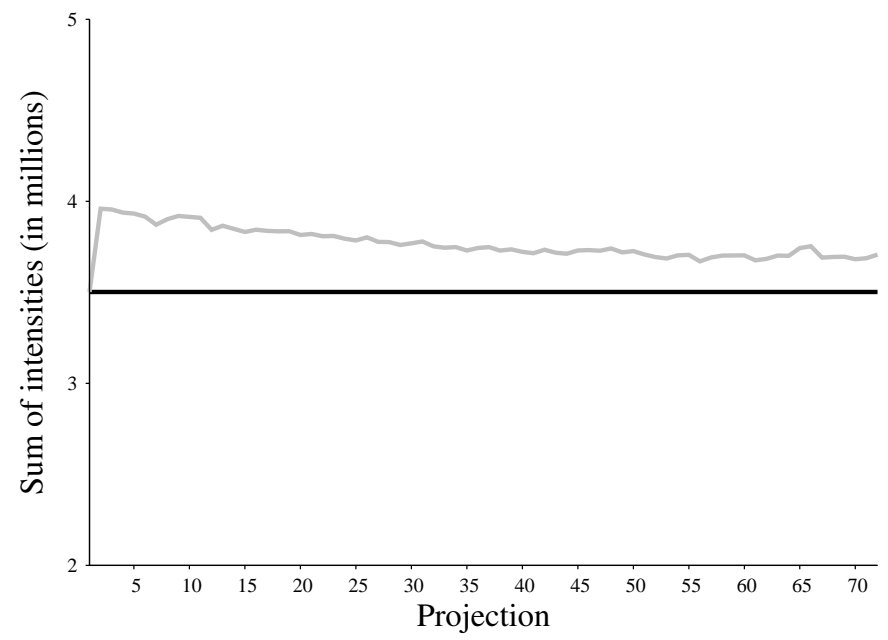

Figure 5.3: Total intensity values in the projections before (grey line) and after (black line) intensity correction.

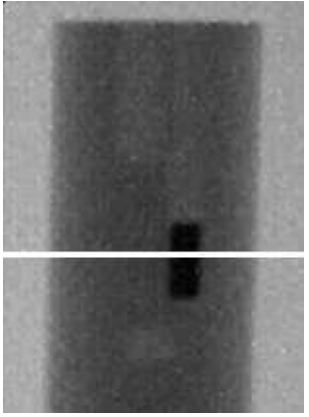

(a)

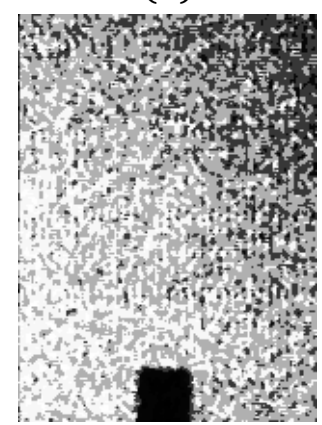

(d)

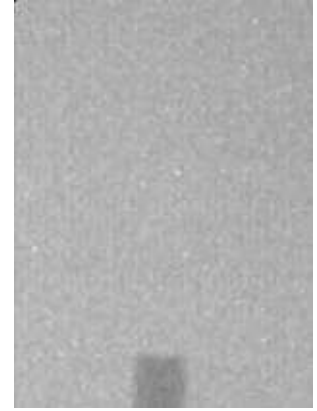

(b)

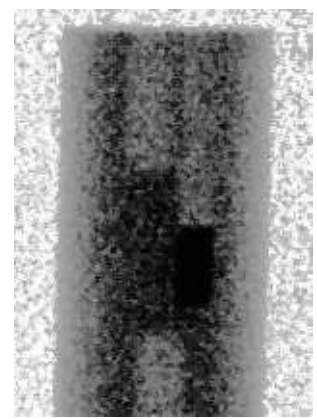

(e)

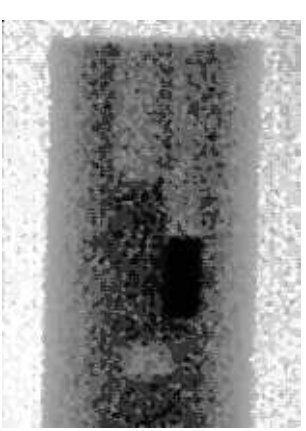

(c)

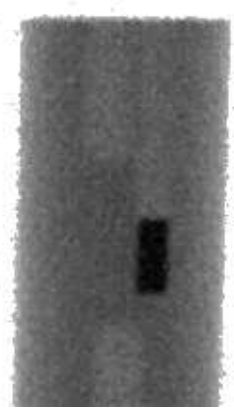

(f)

Figure 5.4: (a) Cropping of the projection image in Figure 5.2(a). The deepest bore contains an aluminum screw at its bottom. (b) The empty image. (c) Histogram equalized version of (a). (d) Histogram equalized version of (b). (e) Histogram equalized version of (a) after intensity and homogeneity corrections. (f) The projection displayed in (a) after intensity correction, homogeneity correction and background subtraction. 


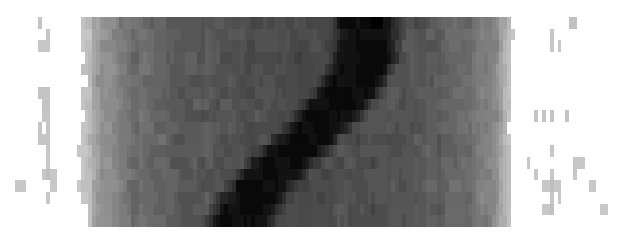

Figure 5.5: Sinogram of 18 projections of the cross-section represented in Figure 5.4(a).

\subsubsection{Determination of intensity levels}

The next problem was that the exact intensity levels of the image to be reconstructed were unknown. Under ideal monochromatic (single-energy radiation) circumstances, the intensity values could be calculated from the linear attenuation coefficients given in the literature. However, the production of monochromatic beams requires expensive and complicated devices, hence they are usually not employed in real experiments. That is, the absorption coefficients calculated in any way, can be viewed as approximate values only. This fact violated one of the basic DT assumptions, namely that the exact attenuation coefficients of the few materials comprising the object should be known in advance. So a technique had to be found to estimate the correct absorption values.

In order to determine the intensity values, the idea [17] was to approximate the discrete image $f$ (recall that $f$ denotes the 3-level image sought) with the reconstruction of another image $\tilde{f}$ having more intensity values than $f$, while the smoothness term is kept turned on in the objective. An approximation of the intensities can be obtained by determining the local maxima in the histogram of $\tilde{f}$.

Accordingly, a reconstruction was carried out using more intensity levels than the number of materials in the object. The enlarged set of intensity levels were produced by the equidistant division of the range of possible intensity levels. For example, if 80 intensity levels are selected from the interval $[0,1]$, the enhanced set of levels is $\{0,1 / 79,2 / 79, \ldots, 1\}$. The more intensity levels used, the more exact an estimation can be achieved, but the number of intensities could not be increased indefinitely as it brought about extremely long run-times.

A reconstruction result, which was obtained using 80 intensity levels got from 18 projections, can be seen in Figure 5.6. To get more homogeneous regions in the reconstruction and, consequently, to get more accurate peaks in the histogram, the smoothness penalty term was kept switched on $(\gamma=2.0)$. As the objective was regularized, the projections were noisy (see figures 5.7(a) and (b)), and the technique is a statistical one, thus the intensity levels obtained are only approximations.

The local maxima in the histogram of $\tilde{f}$ seemed to yield good approximations of the intensity levels to apply in the 3-level DT reconstruction. Since it may be assumed that the intensities have a Gaussian distribution around the original levels, the approximation can be more exact if the values are determined by fitting a sum of the appropriate number (currently three) of Gaussian functions to the histogram. The mean values of these Gaussians can be regarded as approximations of the original values in this case. The fitting operation can be performed by several statistical software packages. The author used SPSS ${ }^{\circledR} 12$ [8] and PeakFit ${ }^{\circledR}[6]$ for 


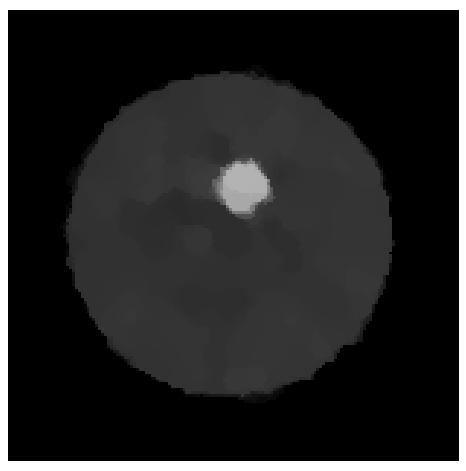

Figure 5.6: A reconstruction result $(155 \times 155)$ calculated via the pixel-based method based on the sinogram shown in Figure 5.5 using 80 intensity levels.

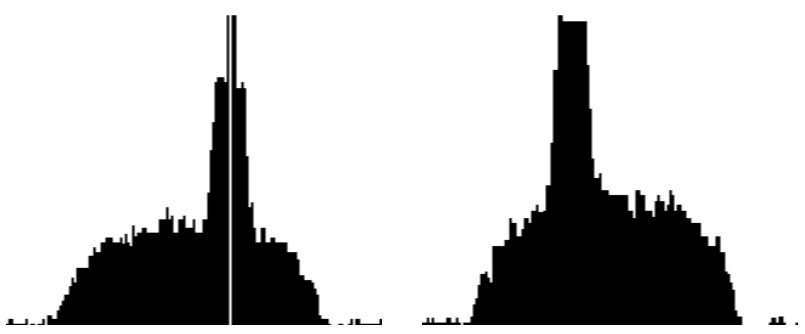

Figure 5.7: Two projections from the sinogram shown in Figure 5.5.

this purpose.

Figure 5.8 shows a histogram plot of the 80-level reconstruction depicted in Figure 5.6, where three accumulation points, 8, 120 and 252 are visible (see pointers). In this way, intensity levels $8 / 255,120 / 255$, and 252/255 were used in the 3-level DT reconstructions. (Recall Section 3.2.2, where it was noted that the internal representation of intensity values is normalized to the interval $[0,1]$, while the visualizations are their natural grey-level depictions using 256 levels.)

\subsubsection{Reconstruction results}

With the three intensity values, which were quite suitable for DT, the multi-level technique was applied. For the sake of comparison, we also performed FBP and ART reconstructions via SNARK93. We chose ART besides FBP because it gave better results than the other classical methods, even when there was a small number of noisy projections available for the reconstructions.

The classical FBP results were calculated using a cosine filter, Lagrange interpolation, and a cut-off frequency of 0.5 , as shown by the SNARK93 command file in Listing C.1. The ART technique performed 100 iterations with the relaxation parameter set to 0.1 . It is also clear in the C. 2 listing that the intermediate images were smoothed in the first 30 iterations, but usually no worthwhile result could be obtained when it was omitted. (A complete reference manual of the SNARK93 programming system can be found in [7].)

For the pixel-based reconstructions the author applied the parameter values 


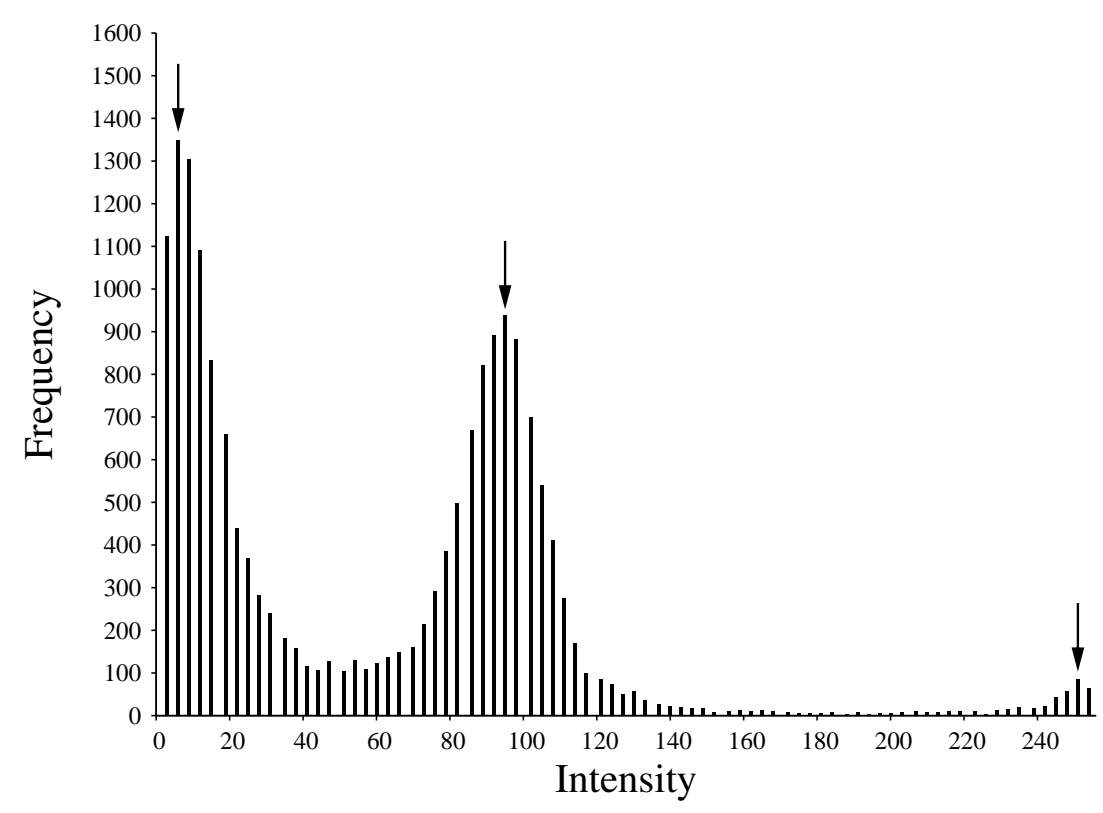

Figure 5.8: Histogram of the reconstructed cross-section in Figure 5.6. Horizontal axis: grey-level intensity value. Vertical axis: frequency of occurrences.

based on the experiences of noisy phantom results, as shown in Table 5.1. The

\begin{tabular}{lc}
\hline Parameter & Value \\
\hline$T^{(0)}$ & 10.0 \\
$h$ & 0.95 \\
$v$ & 5000 \\
$N_{\text {att }}$ & 15000 \\
$N_{r e j}$ & 14999 \\
\hline
\end{tabular}

Table 5.1: Parameters of SA.

DT, FBP and ART reconstructions of the cross-section marked in Figure 5.4(a), got from 18, 12 and 9 projections, can be seen in Figure 5.9. It may be observed that the smaller the number of projections used, the more the sharper streaks degraded the classical results. At the same time, the background was uniformly black in neither the FBP nor the (smoothed) ART reconstructions as it should have been, since the noisy background was subtracted before the reconstructions. Generally speaking, it is obvious that the homogeneous materials do not constitute homogeneous regions in the results of non-DT methods under such circumstances.

So, in this case, the DT technique reflects the real absorption values more realistically than those for FBP and ART because it does not (cannot) show false intensity levels. Instead it breaks up the larger homogeneous regions into smaller ones, and a certain degree of inhomogeneity can be assumed in such cases.

After the reconstruction of all the cross-sections from 9 projections, the slices from 130 to 160 were built up into a 3-dimensional model. For this purpose a 


\begin{tabular}{|c|c|c|c|}
\hline \# of projs & $\overline{\mathrm{DT}}$ & FBP & ART \\
\hline 18 & 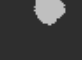 & & $\alpha$ \\
\hline 12 & $C$ & $y$ & 9 \\
\hline 9 & 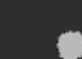 & & 8 \\
\hline
\end{tabular}

Figure 5.9: DT, FBP and ART reconstructions of the same cross-section got from 18, 12 and 9 projections. First column: the number of projections. Second column: DT reconstruction. Third column: FBP reconstruction. Fourth column: ART reconstruction. The images have been rotated by 20, 30 and 40 (360 / number of projections) degrees clockwise.

multi-platform medical data visualizer software package called 3D Slicer [1] was employed, which is designed to process medical image formats, but it can be used in industrial image processing as well. After some preparatory steps the model was visualized via the volume renderer module of the program, and it produced the 3-dimensional object seen in Figure 5.10. Spatial visualization could not be carried out for FBP and ART results, because the images were too inhomogeneous and the streaks corrupted the model.

Exploiting the fact that the object geometry was known, it was possible to check how the reconstruction preserved the original structure. For example, according to Figure 5.1, the ratio of the diameters of the cylinder and the deepest hole was $30 \mathrm{~cm} / 5 \mathrm{~cm}=6$, while the same ratio in the image got from 9 projections was $110 \mathrm{pixel} / 18 \mathrm{pixel} \approx 6.11$. In general, the DT results successfully reflected the geometry well apart from a few small deviations.

\subsection{Reconstruction of an aluminum cylinder from neu- tron projections}

The author was also supplied with the neutron projections of a reference cylinder made of aluminum. The bores contained two kinds of fluids during the acquisi- 

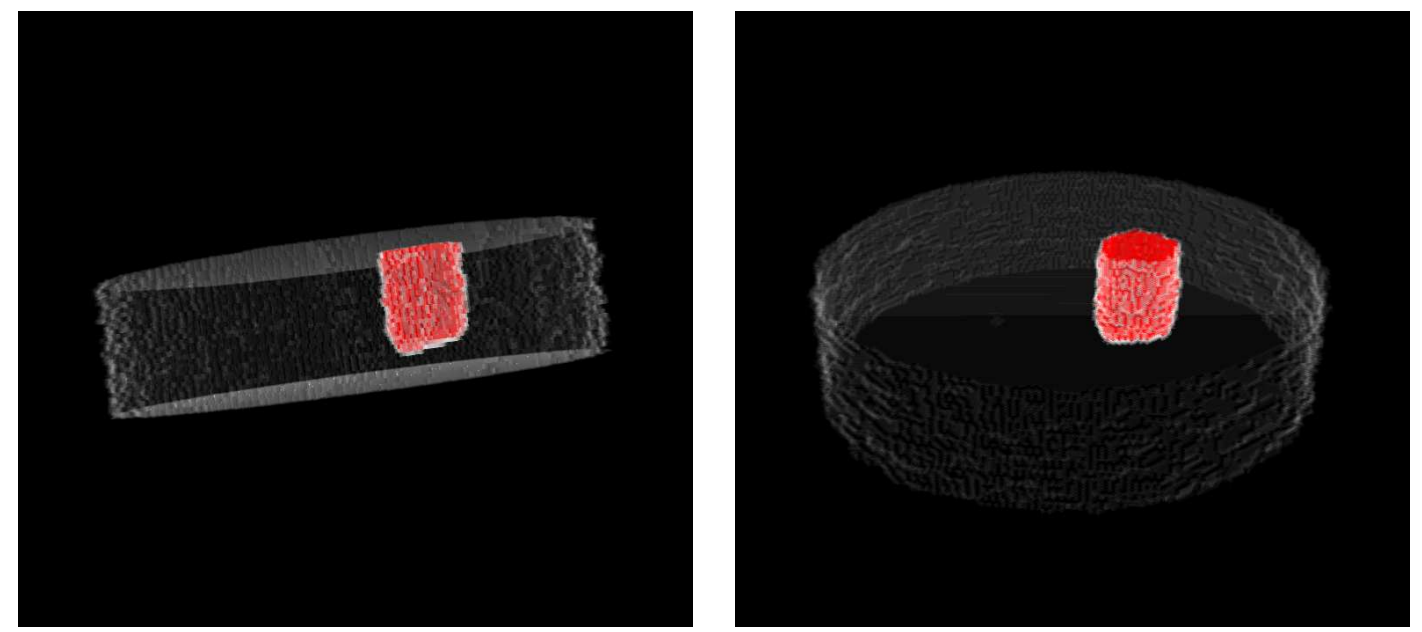

Figure 5.10: Two 3-dimensional volume-rendered views of the Plexiglas cylinder reconstructed from 9 projections by the DT method. The slices are visualized from 130 to 160 . Colours: black - air, grey - cylinder, red - screw.

tion in this case, where the bore of the biggest diameter was filled up with water, and there was acetone in the others. That is, the object was composed of three materials that had different neutron attenuation coefficients. As for the Plexiglas cylinder, substitution of the materials was reasonable due to the similar attenuation properties of Plexiglas and aluminum found when using the neutron radiation source.

There were 180 projections taken with an angular spacing of $1^{\circ}$, and even an empty image was projected. The dimensions of the original images were $365 \times 400$. One of the projection images and the empty image are visible in figures 5.11(a)-(b).

\subsubsection{Pre-processing}

Although the appearance of the projections was good, the projections seemed to be degraded by a number of imaging artifacts. They were obvious especially in the histogram equalized version of the projections and the empty image (figures 5.11(c)(d)). The darker border and lighter central region were caused by the burn-out of the detector plane, which was fixed by the homogeneity correction. This preprocessing step also eliminated the vast majority of white spots co-located in the projections and the empty image. The results of the homogeneity correction are shown in Figure 5.12. The remaining white specks were removed by the thresholded $(\mathrm{thr}=30)$ median filter.

Lastly, the varying total intensities of the projections (Figure 5.13) had to be corrected. A difference of over 3\% total intensity values could be identified between the lightest and darkest images, thus an additional intensity correction was applied. 


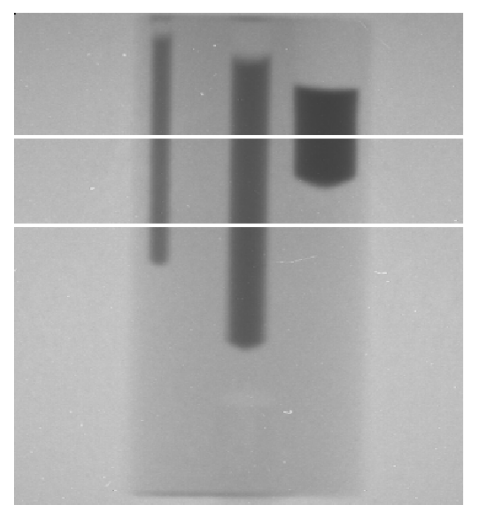

(a)

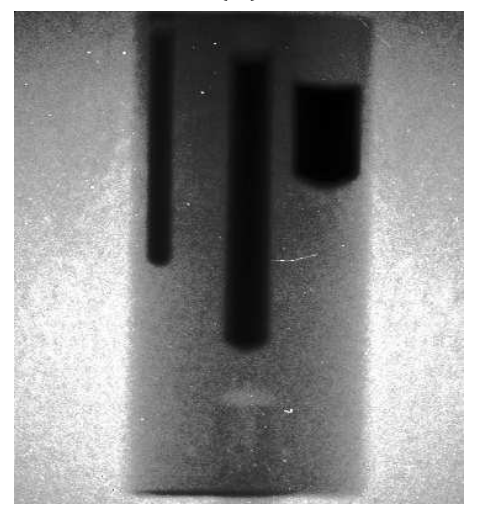

(c)

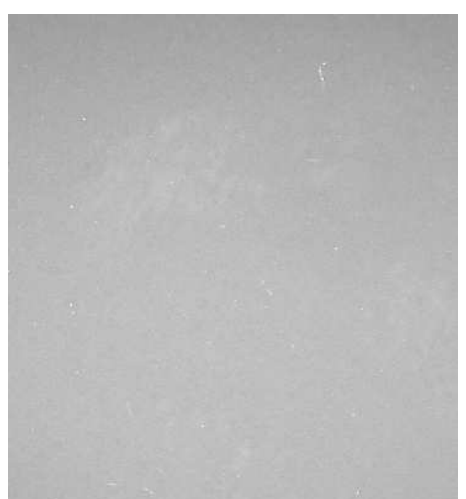

(b)

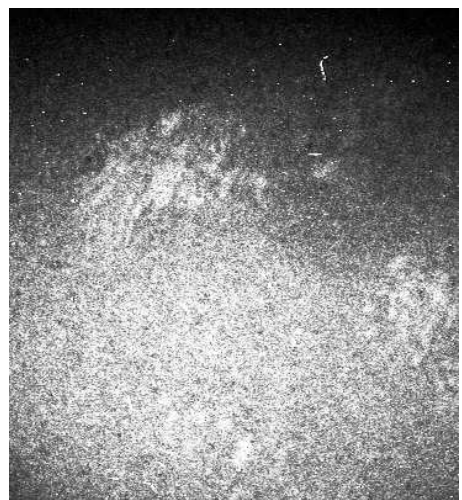

(d)

Figure 5.11: (a) A neutron projection of the aluminum reference cylinder. The bores contain fluids. (b) The empty image. (c) Histogram equalized version of (a). (d) Histogram equalized version of (b).

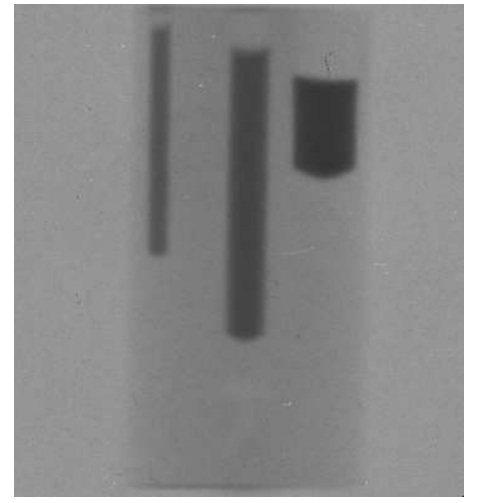

(a)

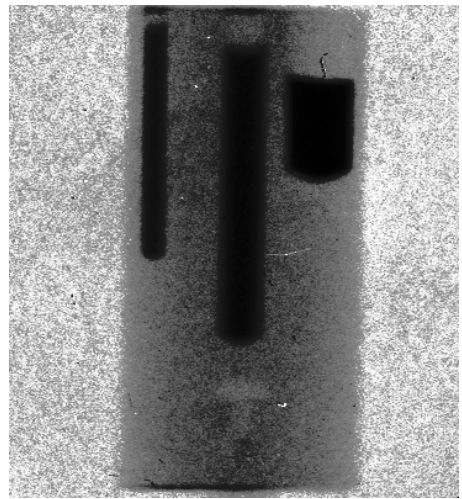

(b)

Figure 5.12: (a) Homogeneity corrected version of Figure 5.11(a). (b) Histogram equalized version of the projection in (a). 


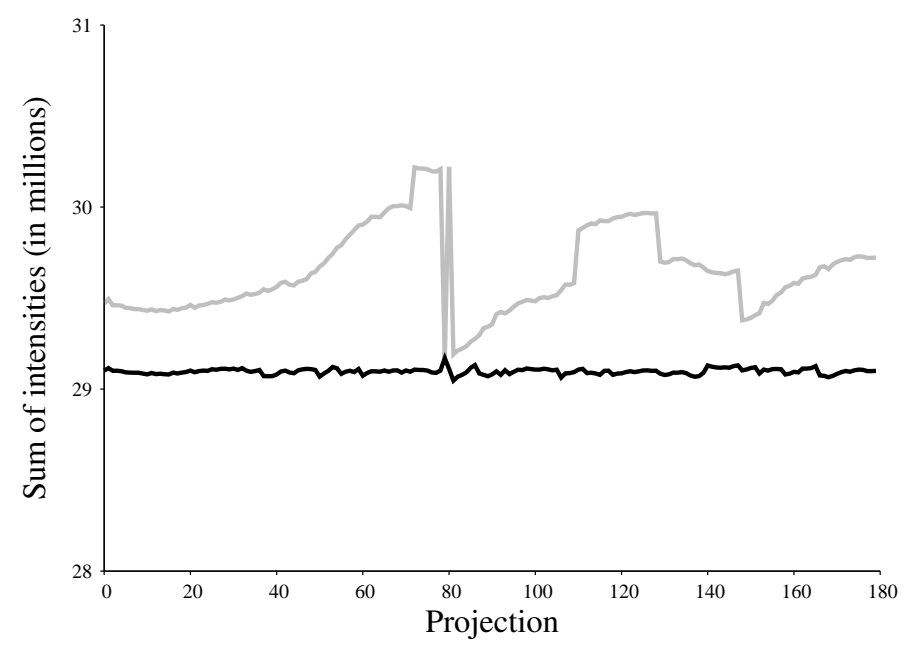

Figure 5.13: Total intensity values in the projections before (grey line) and after (black line) intensity correction.

\subsubsection{Determination of intensity levels}

The intensity levels were determined using the same technique as that described in Section 5.1.2. A reconstruction was performed from 10 projections using 256 intensity levels, while having the smoothness penalty term switched on in the objective $(\gamma=1.0)$. The resultant image in Figure 5.14 clearly reflects the background and the 2 materials comprising the reconstructed cross-section. From a DT re-

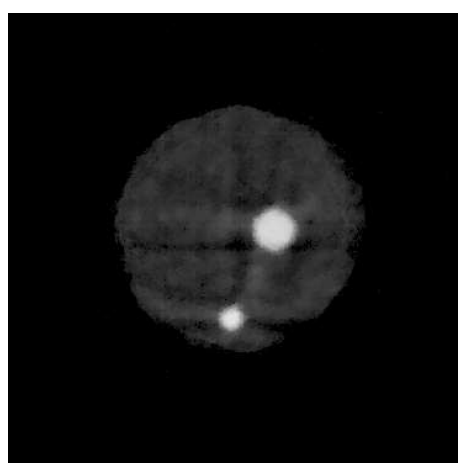

Figure 5.14: 256-level DT reconstruction of the second cross-section marked by the lower line in 5.11(a) got from 10 projections.

construction point of view, the peaks in the histogram yielded the intensity levels $0,5 / 255$ and 170/255 later used in the reconstruction. Since the histogram of Figure 5.14 contained a few high and a number of relatively small values, a logarithmic histogram was plotted in Figure 5.15.

\subsubsection{Reconstruction results}

First, a continuous FBP reconstruction was carried out using all 180 projections, where the resultant cross-sections (see Figure 5.16) displayed marked inhomogene- 


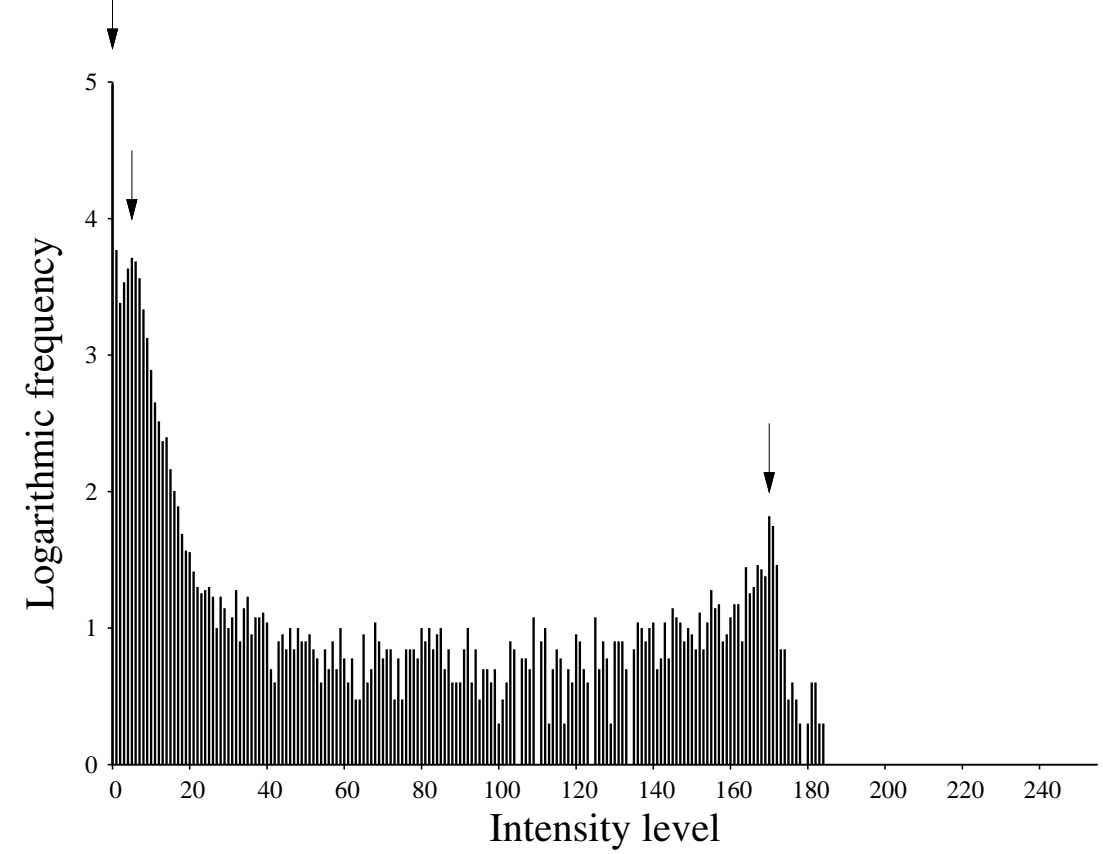

Figure 5.15: Logarithmic histogram of the cross-section in Figure 5.14. Horizontal axis: grey-level intensity value. Vertical axis: base 10 logarithm of the frequency of occurrences.

ity. These shadow-like artifacts were probably caused by the hardening property of neutron beams, and can also be observed in Figure 5.14. The DT technique has a certain tolerance towards such artifacts when the smoothing term is switched on in the objective; small local features and details are, however, expected to degrade in this case. Since the slices containing four materials (Figure 5.16(a)) were too inhomogeneous even for the DT reconstruction, the method was applied only for the cross-sections that comprised fewer intensity levels. The inhomogeneity could still be managed in these cases.

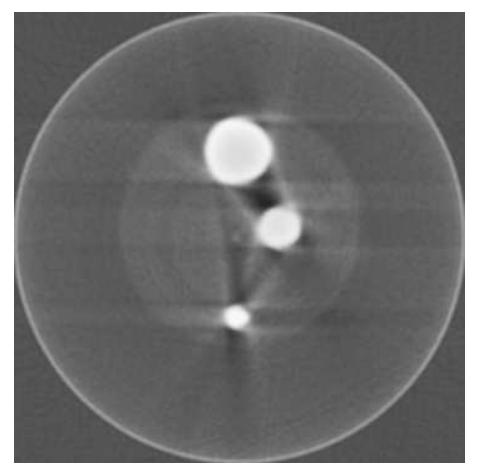

(a)

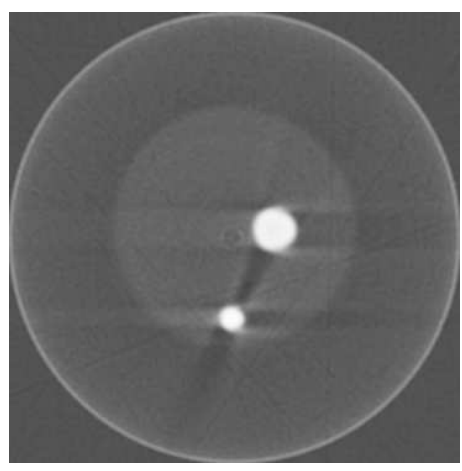

(b)

Figure 5.16: Brightness and contrast adjusted filtered back projection results of the two cross-sections marked in 5.11(a). The reconstruction was carried out using 180 projections.

As already indicated above and predicted by the classical results got from a small number of projections, we expected a significant level of inhomogeneity to be corrected by the smoothing regularization term. The DT results were generated 
by employing the reconstruction parameters given in Table 5.1 and the relatively high $\gamma=7$.0. After performing the 3-level reconstruction from 10 projections, the method produced the slice depicted in Figure 5.17.

\begin{tabular}{|c|c|c|c|}
\hline \# of projs & DT & FBP & ART \\
\hline \hline & & & \\
10 & & & \\
& & & \\
& & & \\
\hline
\end{tabular}

Figure 5.17: DT, FBP and ART reconstructions of the cross-section marked by the lower line in 5.11(a) got from 10 projections. First column: the number of projections. Second column: DT reconstruction. Third column: FBP reconstruction. Fourth column: ART reconstruction.

Although some distortions (fuzzy region borders, geometrical deformations) are visible in the pixel-based cross-section, the object is not fragmented in spite of the strong beam hardening effect. The diameter of the reconstructed cylinder varied between 190 and 200 pixels, while the bigger bore was around 31 pixels wide. That is, the ratio of the diameters gives $195 \mathrm{pixel} / 31$ pixel $\approx 6.29$ if the diameter of the cylinder is assumed to be 195 pixels. It gives a deviation of about $5 \%$ compared to the expected value of 6 (refer to Figure 5.1), which was probably caused by the combined effect of the big $\gamma$ and the fact that the intensity levels are only the discrete approximations of the real ones.

Comparing the pixel-based result with the FBP cross-section, it is readily seen that the cylinder almost completely vanished from the FBP and ART images, and it can be stated that the DT technique without a doubt outperformed the classical methods on the same given tasks.

\subsection{Reconstruction of an iron cylinder from gamma- ray projections}

Lastly, the third physical phantom was a cylinder made of iron, where the bottom of the bores had lead membranes that were rolled up. There were 180 projections taken using a $1^{\circ}$ angular difference, and each projection image had the dimensions $157 \times 217$. Though the background intensity, seen in Figure 5.18, was constant, the beams passing through the object provided an extremely low projection quality.

\subsubsection{Pre-processing}

The visible part of the background in Figure 5.18 reflected a uniformly sensitive detector plane; thus, in contrast with the other reference objects, there was no background image recorded here. The only two issues, which could be seen in the 


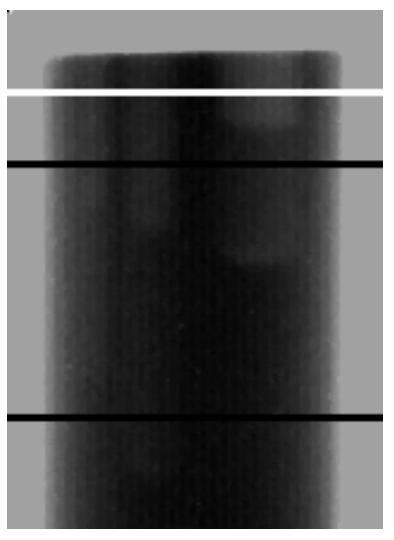

(a)

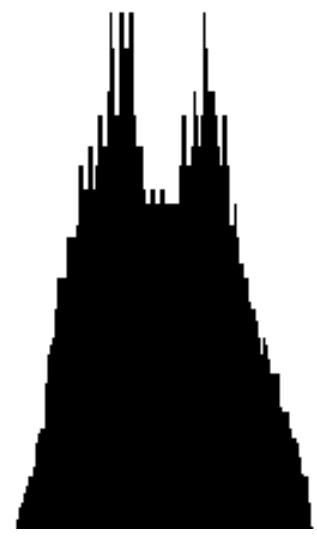

(b)

Figure 5.18: (a) The $150^{\circ}$ projection of the iron cylinder. (b) The projection vector marked by the white line in (a) as a bar diagram. (The background was subtracted.)

projections, were the small amount of oscillations in the total intensity values and the vertical streaks appearing in Figure 5.18. The oscillation problem was corrected by intensity correction, but the latter could not be attributed to any of the wellknown distortions, hence it could not be diminished. This eventually led the author to think that the projections were seriously inconsistent in some way.

\subsubsection{Determination of intensity levels}

The intensity levels $(0,14 / 255$ and $24 / 255)$ were estimated by utilizing the same technique as in the preceding examinations. It is clearly seen that the values covered a relatively small portion of the interval $[0,1]$, which did not affect the optimizer, but could cause some inaccuracy in the determination of intensity levels. Generally speaking, the broader the interval the intensities span (within $[0,1]$ ), the better the estimates of levels can be.

\subsubsection{Reconstruction results}

The author performed DT reconstructions from 9 and 6 projections and applied the optimization parameters summarized in Table 5.2. Choosing $h=0.975$ meant a fairly slow temperature reduction, which was reasonable due to the distorted and uncorrected, hence possibly inconsistent projections.

Three cross-sections were reconstructed, depicted by the white and black lines in Figure 5.18. The first slice (white line) crosses air and iron, while the other ones (black lines) intersect air, iron and lead. The results from 9 projections are displayed in Figure 5.19. The noise sensitivity of FBP yielded strong streaks in the reconstructions, and made the cylinder almost unidentifiable. ART gave better results, but a fair degree of smoothing had to be applied along with the reconstruction, which produced softer streaks but smoothed the edges. The DT method performed the best for the 35th slice, but this cross-section was reconstructed as a 2-level image, as this slice intersected air and iron only. In order to get homogeneous regions 


\begin{tabular}{lc}
\hline Parameter & Value \\
\hline$T^{(0)}$ & 10.0 \\
$h$ & 0.975 \\
$v$ & 5000 \\
$N_{a t t}$ & 15000 \\
$N_{r e j}$ & 14999 \\
\hline
\end{tabular}

Table 5.2: Parameters of SA.

and compensate for the uncorrected distortion as well as the noise content of the projections, the regularization coefficient $\gamma=1.5$ was applied in the penalty term.

\begin{tabular}{|c|c|c|c|}
\hline \# of slice & DT & $\mathrm{FH}$ & ART \\
\hline 35 & & & \\
\hline 65 & & & \\
\hline 170 & & & \\
\hline
\end{tabular}

Figure 5.19: DT, FBP and ART reconstructions of three cross-sections marked in Figure 5.18(a) got from 9 projections. First column: number of the slice. Second column: DT reconstruction. Third column: brightness, contrast and gamma adjusted FBP reconstruction. Fourth column: brightness, contrast and gamma adjusted ART reconstruction.

The 65th and 170th slices crossed air, iron and the lead rolls as well, hence they had to be treated as 3-level discrete image functions. The more difficult geometry, the three intensity levels, and the uncorrected distortion made it necessary to increase the weight of the penalty term to $\gamma=2.5$. The increased coefficient resulted in a spurious lead annulus on the region borders between air and iron, and narrowed the bores compared with those seen in the classical results. This latter outcome is reasonable, if it is taken into account that the lead rolls could not be regarded homogeneous, which probably contributed to the low reconstruction quality 
of the slices investigated.

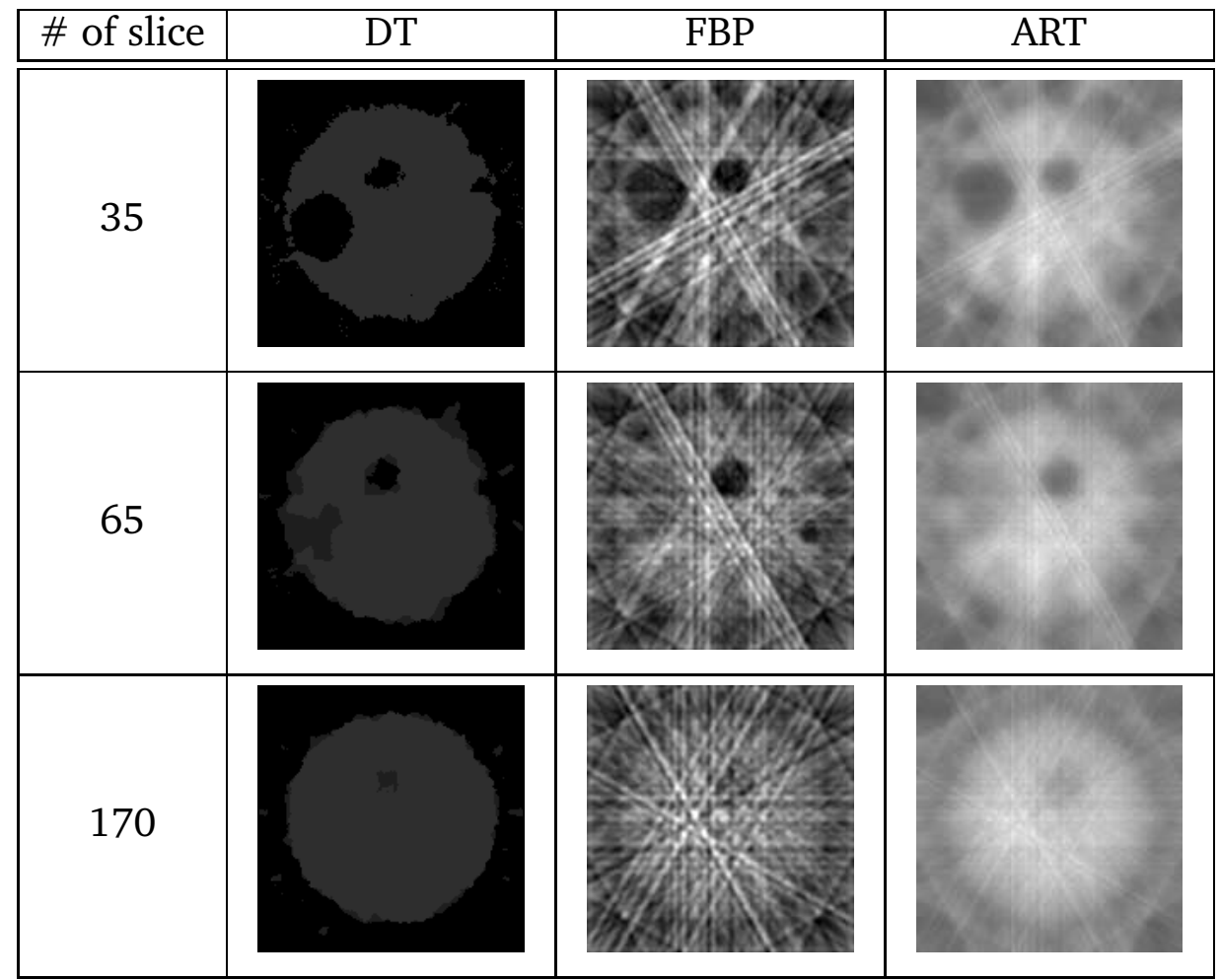

Figure 5.20: DT, FBP and ART reconstructions of three cross-sections Figure 5.18(a) got from 6 projections. First column: number of the slice. Second column: DT reconstruction. Third column: brightness, contrast and gamma adjusted FBP reconstruction. Fourth column: brightness, contrast and gamma adjusted ART reconstruction.

Reducing the number of projections to 6 (see Figure 5.20), the DT reconstruction $(\gamma=1.5)$ of the 35 th cross section still reflected the geometrical properties better than that for FBP, and ART, where the smallest bore almost vanished. In the 3-level cases the lack of information caused by the relatively few number of projections had to be compensated for by the a priori smoothness, otherwise the regions would have fragmented. By contrast, the strong smoothing term almost made the bore disappear in the 170th slice and also corrupted the 65 th one.

As regards the ratios of diameters in the 35th slice got from 9 projections, the ratio of the diameter of the reconstructed cylinder and the biggest bore was about $125 \mathrm{pixel} / 35 \mathrm{pixel} \approx 3.57$. Comparing this with the theoretical $30 \mathrm{~cm} / 8 \mathrm{~cm}=3.75$, a small inaccuracy (about 5\%) could be observed. Since the bores could not be restored satisfactorily in the other slices, this ratio could not be applied to the other reconstructed cross-sections.

\subsection{Summary}

In this chapter, the author presented the first real applications performed on three reference cylinders containing bores of different depths. The objects had the same 
and known geometry, but three different radiation sources were applied for imaging the cylinders. The author analyzed the projection images and provided the results of the pre-processing steps that were applied. Next, the pixel-based reconstruction results were given, where the author performed the classical FBP and ART reconstructions as well. Here it was clearly seen if the goal was a 3-dimensional visualization of the object based on its reconstructed cross-sections, the pixel-based reconstructions yielded more suitable slices than the classical techniques. Lastly, as the attenuation coefficients of the materials constituting the object were unknown, the author also introduced a technique to approximate the intensity values used for the reconstructions. 


\section{Chapter 6}

\section{Reconstructions of physical objects}

Here it was quite interesting to see how the method would perform when the discrete set of intensity levels could not be determined. It may happen when the object contains inhomogeneous materials, for instance. In this case an enhanced set of intensity levels must be applied for the reconstruction, which can be achieved by the proper equidistant discretization of the full range of possible intensity levels, as was done in the determination of the intensity levels. In this way, the reconstructed cross-section cannot really be regarded as a discrete image or a continuous one, but it may lie somewhere between the two. Here the reconstruction results of the method on the projections of a cardiac pacemaker battery and the control rod of an atomic reactor are presented, where the homogeneity of the constituting materials was not presumed.

The author published the results of this chapter in $[13,42]$.

\subsection{Reconstruction of a cardiac pacemaker battery}

The author was contacted by physicists from the Hahn-Meitner Institute, who wanted to know whether the DT method was capable of reconstructing the battery of a pacemaker using just a small number of projections [42]. The battery was composed of two main components, namely the intrinsic part containing the electrically charged material, and its housing (see the projection in Figure 6.1(a)). It was a topic of interest because there is a strong connection between its lifetime and the distribution of the charged material, hence the physicists wanted to have a spatial model so as to inspect the intrinsic part.

There were 200 neutron projections ${ }^{1}$ acquired equiangularly with a spacing of $0.9^{\circ}$, where each projection had a size of $447 \times 512$. Although the number of projections was large, it was intended to be reduced in the subsequent examinations of other pacemaker batteries. As shown in Figure 6.1(a), but especially in Figure 6.1(b), the projections were almost noiseless and of good quality, thus there was no need for pre-processing.

\footnotetext{
${ }^{1}$ The projections were provided by Prof. Wolfgang Treimer (Hahn-Meitner Institute, Berlin).
} 


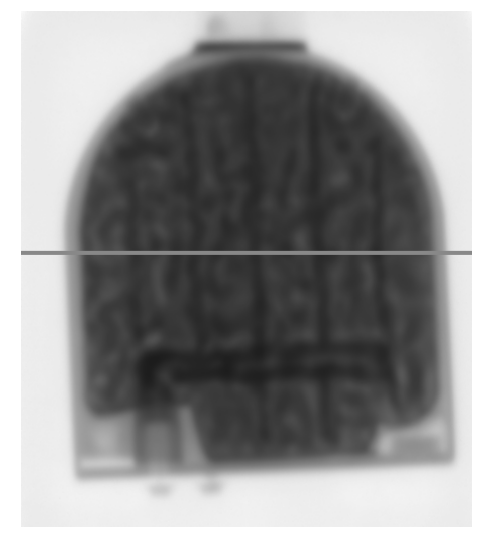

(a)

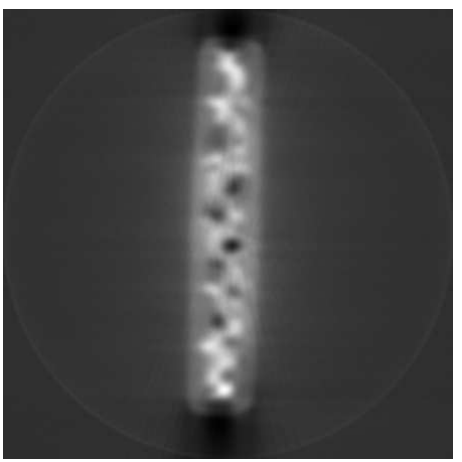

(c)

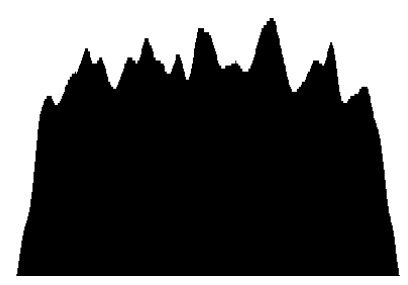

(b)

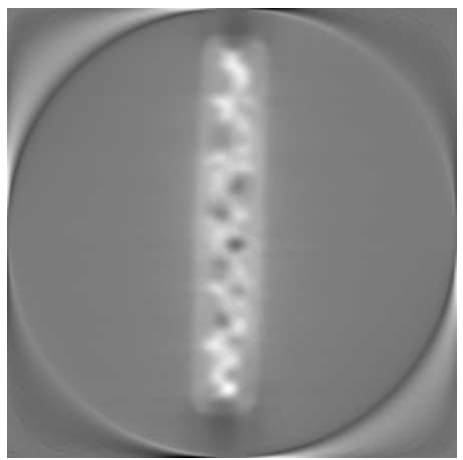

(d)

Figure 6.1: (a) One of the neutron projections of a pacemaker battery. (b) The bar diagram representing the projection marked in (a). (c) FBP and (d) ART reconstructions of the crosssection shown in (a) using 200 projections.

\subsubsection{Reconstruction results}

First, the classical techniques were performed using the full set of 200 projections. One of the projections is shown in Figure 6.1(b), while the corresponding reconstruction result based on 200 projections using the FBP and ART methods of SNARK93 can be seen in figures 6.1(c)-(d), respectively. For the classical reconstructions the same SNARK command files were employed, as given in listings C.1 and C.2. In both continuous reconstructions a certain degree of beam hardening can be observed, which appear as dark shadows at the top and bottom of figures 6.1(c)(d). It predicted that this region would be reconstructed improperly as well in the DT cross-sections.

In order to see how the DT technique behaves when only a small number of projections but 256 intensity levels are provided, reconstructions were made from 20 and 10 projections using the parameters given in Table 6.1. Since the projections were perfect and no meaningful distorting effect could be identified, a quicker temperature reduction $(h=0.9)$ was a reasonable decision. Recall that the lower a $h$ value is used for the reconstruction, the more CPU time one can expect to save, especially in the case of large images. For the sake of comparison, FBP and ART 
were also performed with the same input data. In Figure 6.2 the DT and classical results from 20 and 10 projections are presented after brightness, contrast and gamma adjustment. It is seen that the classical cross-sections became very streaky due to the non-ideal conditions for a continuous reconstruction. Apart from the background homogeneity, the DT method did not yield a remarkably better result than the classical methods in the case when 20 projections were used. However, when the number of projections fell to 10, the DT technique still performed well, while the FBP method failed, and the ART results became blurred.

\begin{tabular}{lc}
\hline Parameter & Value \\
\hline$T^{(0)}$ & 10.0 \\
$h$ & 0.9 \\
$v$ & 5000 \\
$N_{a t t}$ & 15000 \\
$N_{r e j}$ & 14999 \\
\hline
\end{tabular}

Table 6.1: Parameters of SA.

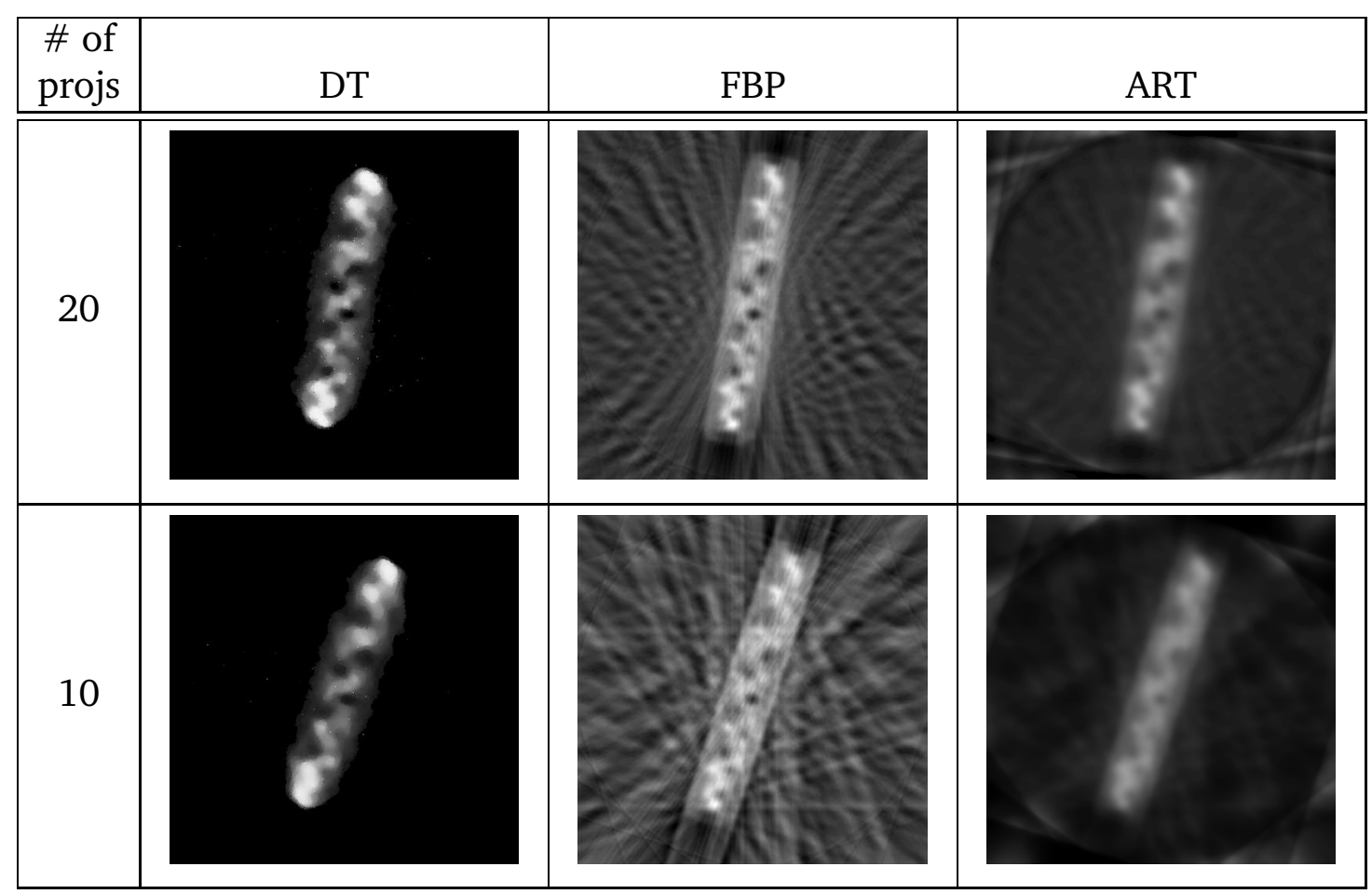

Figure 6.2: Reconstructions of the slice marked in Figure 6.1(a) based on 20 and 10 projections. First column: the number of projections. Second column: brightness, contrast and gamma adjusted DT reconstruction. Third column: brightness, contrast and gamma adjusted FBP reconstruction. Fourth column: brightness, contrast and gamma adjusted ART reconstruction.

After the reconstruction of 50 slices, the cross-sections were turned into a 3dimensional volume-rendered model (Figure 6.3). In spite of the severe conditions, 
the irregular distribution of charged material is quite visible in each DT reconstruction in Figure 6.2, and even clearer via multiple cross-sections in the volumerendered spatial model in Figure 6.3.
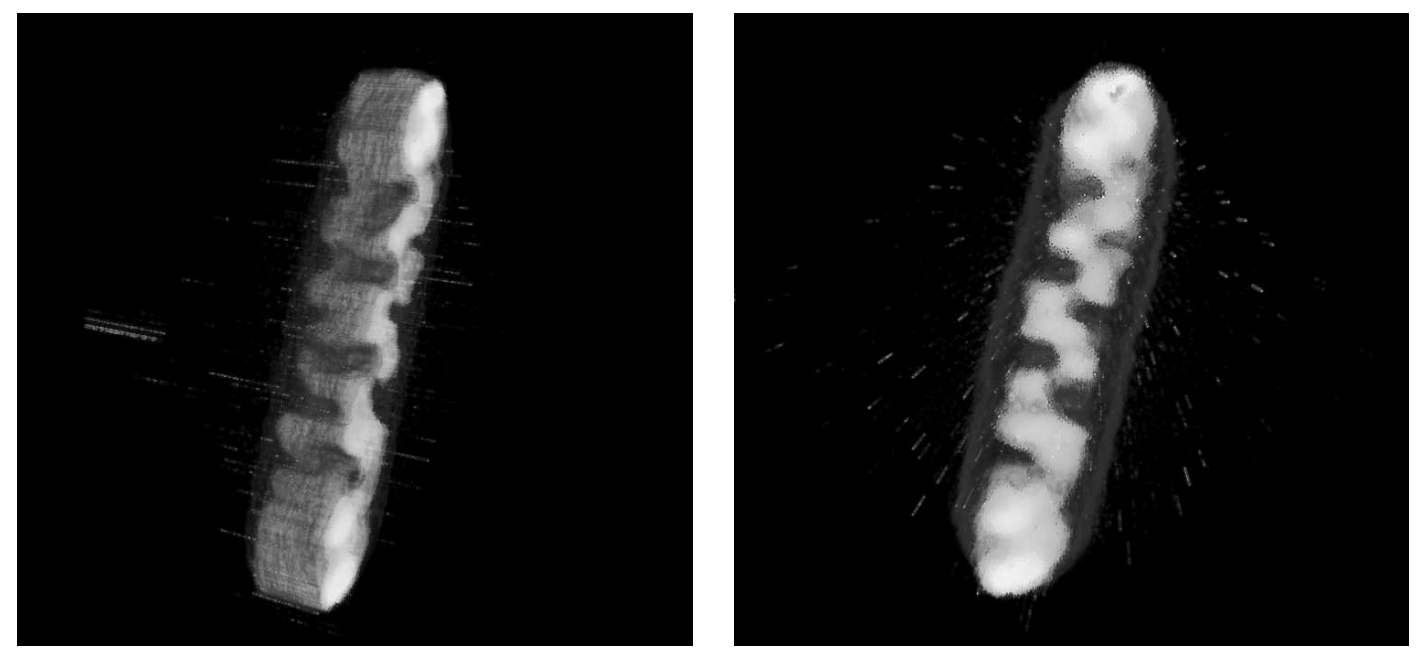

Figure 6.3: Two different volume-rendered views of the pacemaker battery. (Slices from 200 to 249,20 projections.)

From a run-time perspective, the technique cannot be said to be fast in the case of real measurements and an enlarged number of intensity levels. As already stated in previous sections, the speed depends on the input data as well as the temperature scheduling. A reconstruction from the pacemaker projections using hundreds of intensities can cost a couple of hours. The average run-time using 10 projections and 256 intensity levels was around 70 minutes. Thus, the reconstruction time of cross-sections for the 50 -slice spatial model was about 2.5 days.

\subsection{Reconstruction of a boron-carbide control rod}

Another live test [13] was performed on the projections of a control rod (Figure 6.4). Control rods are usually made of a tube filled with a neutron absorber, where the absorber is a chemical element with a high neutron absorption capability used to moderate the particle flux within the reactor core. However, any undesirable changes in the distribution of the absorber adversely affects its effectiveness, so it was a vital examination from a nuclear reactor safety point of view.

There were 18 neutron images ${ }^{2}$ taken from a single control rod having an aluminum wall (1 mm thickness) and containing a boron absorber. The goal of the examinations was to find evidence and visualize the irregular absorber distribution, especially at the bottom of the rod, where even the presence of bubble-like helium accumulations were supposed (Figure 6.5).

\footnotetext{
${ }^{2}$ The projections were provided by Prof. Márton Balaskó (Hungarian Academy of Sciences KFKI Atomic Energy Research Institute, Budapest).
} 


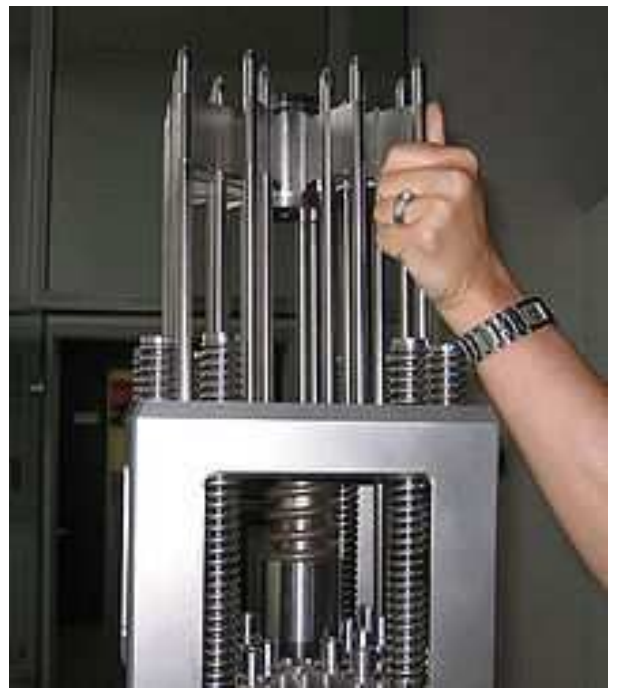

Figure 6.4: Control rods are usually combined into assemblies. Source: Wikipedia.

\subsubsection{Pre-processing}

Even though the object was accurately rotated by a special device (as it could not be placed on a rotating table), the position of the detector plane was imprecisely adjusted between the acquisitions of two neighbouring projections. It caused projections like these, which contained translated and/or rotated versions of the expected images. Since the object could be treated as circularly symmetric, this distortion was corrected by applying rigid registration on the projections. Two of the registered $611 \times 3470$ projections are displayed in Figure 6.5.

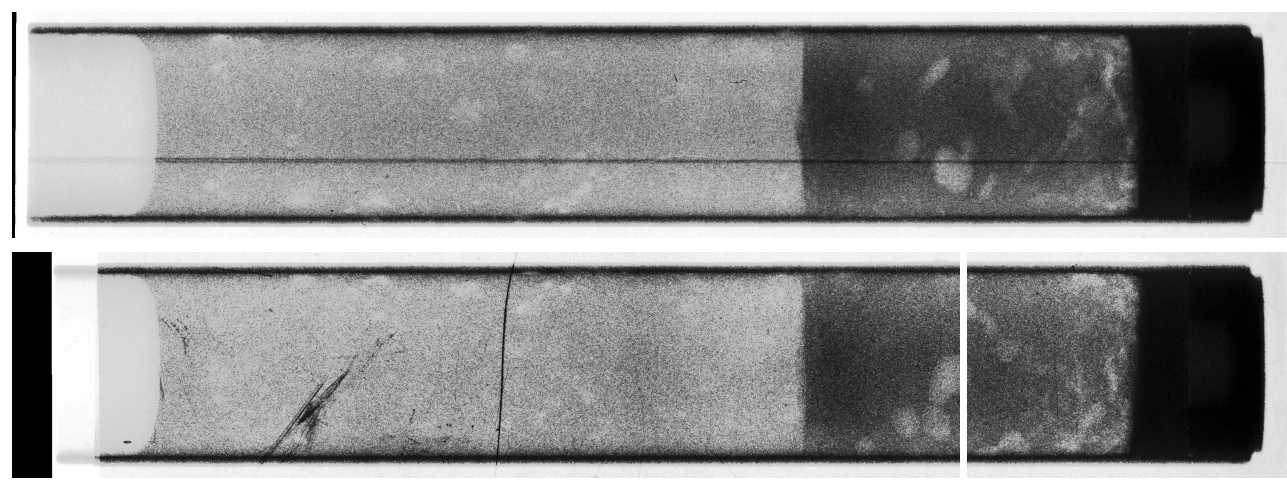

Figure 6.5: $10^{\circ}$ and $70^{\circ}$ projections of the control rod after a rigid registration and brightness, contrast, gamma adjustment. The images have been rotated by $90^{\circ}$ counterclockwise. The darker lower section is boron-carbide with supposed helium inclusions.

Although strong flickering was visible while playing the 18 projections as a movie, the effect could not be diminished by further pre-processing steps because the problem was caused by neither homogeneity nor intensity distortions. In addition, Figure 6.6 makes it clear that the projection vectors were of a very low quality. There were fewer than 20 dominating intensity levels in the histograms and the im- 
ages were quite noisy; moreover, the three detector planes used for the acquisitions were also worn-out and damaged, causing the sharp black smears and streaks seen in Figure 6.5. Such smears appeared in most of the projections and their widths often exceeded 10 pixels.

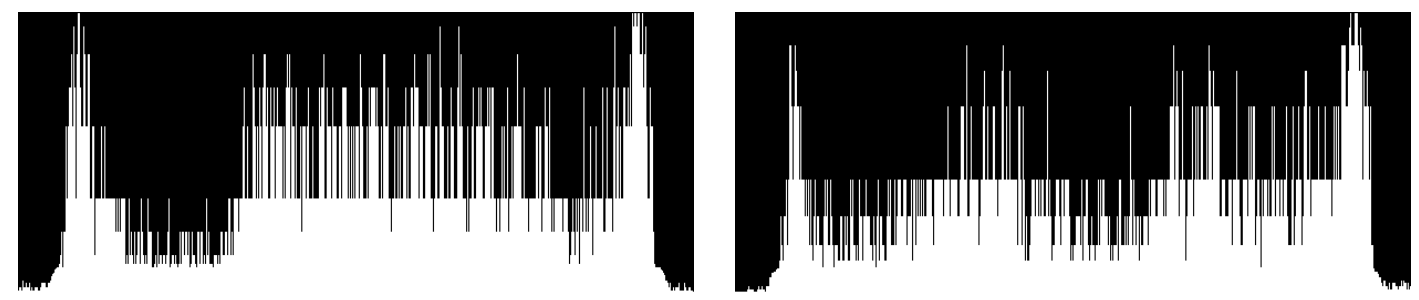

Figure 6.6: Two different $\left(60^{\circ}\right.$ and $\left.150^{\circ}\right)$ projection vectors of the 2585 th slice marked by the line in Figure 6.5.

\subsubsection{Reconstruction results}

Although it was assumed that the distribution of absorber material was inhomogeneous, the control rod was also reconstructed as a 3-level object from 9 projections. The application of the pixel-based technique under such circumstances means one expects the bad reconstruction of the absorber part, which was confirmed by the 3-dimensional model of the reconstructed slices in Figure 6.7. It is quite apparent that the DT technique still performed well at the bottom of the rod (right hand side of Figure 6.7(b)) where no absorber was present in the cross-sections, but the images became seriously corrupted as soon as the boron-carbide part appeared in the slices.

Since the goal was also to establish the presence of helium bubbles within the absorber, and better results could be expected when 256 intensity levels were applied during the reconstructions with the smoothing penalty term turned on, 100 cross-sections (from 2451 to 2550) of size $611 \times 611$ were reconstructed from 6 and 9 projections. The reconstruction parameters and values listed in Table 6.2 reveal that the cooling factor was kept at a relatively high level $(h=0.985)$ due to the noisy and presumably inconsistent projections. It is also noticeable that even the termination criterion giving the efficiency had to be lowered. It resulted in longer reconstructions (20-30 minutes per cross-section), but a premature termination could not be avoided using the earlier set-ups. In spite of these adjustments we still experienced noisy results, which were caused by the fact that the variances ( $\sigma_{1}$ and $\sigma_{2}$ ) were calculated from a small sample, and the equilibrium states detected by the optimizer were not true equilibria. Therefore, an augmented $v$ was employed during the optimization. That is, the experience gained with fine-tuning the reconstruction parameters presented in Section 3.3 was cleverly exploited here.

The suspected inhomogeneity could be clearly seen as two spots in the lower half region of both DT and ART reconstructions (Figure 6.8), while the poor FBP results did not display the artifacts satisfactorily. With the DT results, further inhomogeneity appeared in the upper intrinsic area along the wall of the rod, but it was 


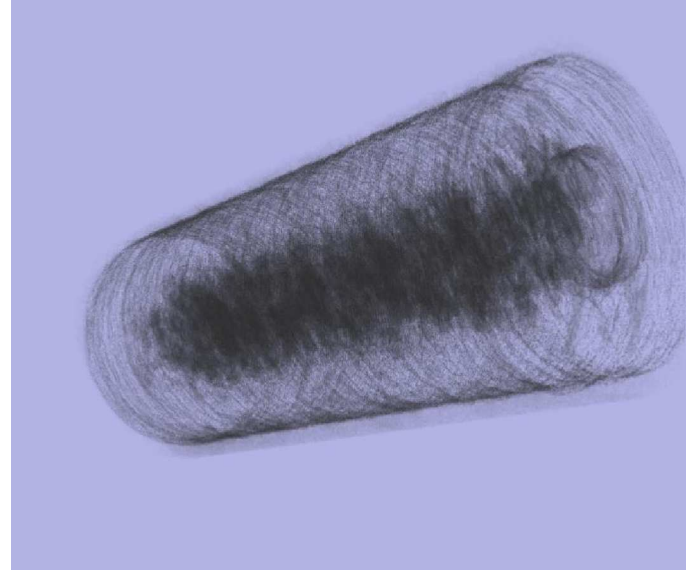

(a)

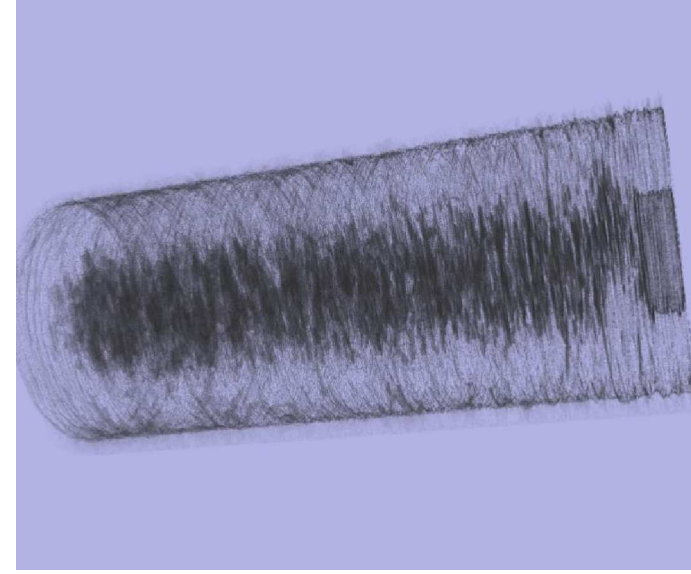

(b)

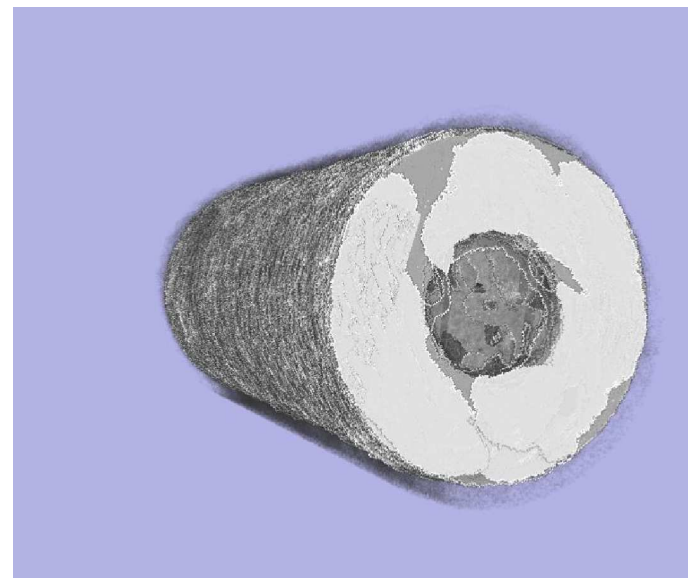

(c)

Figure 6.7: (a)-(b) Volume-rendered 3-dimensional visualizations of the control rod with a transparent wall. (c) Volume-rendered 3-dimensional visualizations of the control rod with a non-transparent wall. The intensity values used for the reconstructions were estimated by applying the same technique as before.

\begin{tabular}{lc}
\hline Parameter & Value \\
\hline$T^{(0)}$ & 10.0 \\
$h$ & 0.985 \\
$v$ & 15000 \\
$N_{a t t}$ & 20000 \\
$N_{r e j}$ & 19999 \\
\hline
\end{tabular}

Table 6.2: Parameters of SA. 
not unequivocally attributable to the material distribution. The most convincing evidence of helium bubbles can be observed in the spatial visualization in Figure 6.9, where a large cavity was present via multiple slices.

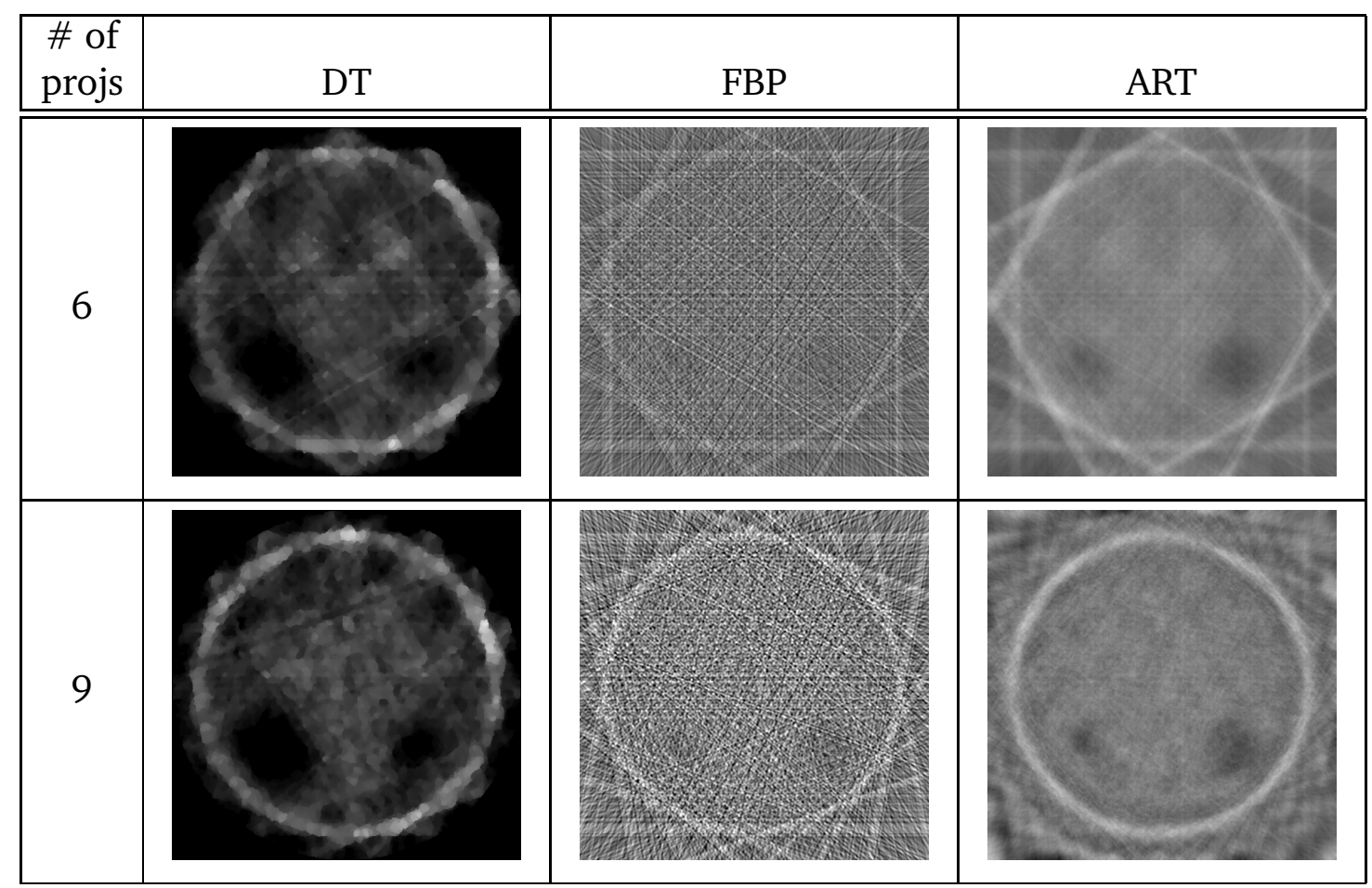

Figure 6.8: Reconstructions of the 2585th slice using DT, FBP and ART techniques. First column: the number of projections. Second column: brightness, contrast and gamma adjusted DT reconstructions. Third column: brightness, contrast and gamma adjusted FBP reconstruction. Fourth column: brightness, contrast and gamma adjusted ART reconstruction.

\subsection{Summary}

In this chapter the author introduced two real (non-reference) objects, where the homogeneity of the materials could not be assumed. As the original version of the pixel-based method cannot be applied under such circumstances, the author performed the reconstruction by employing an increased number of intensity levels along with the smoothness regularization term.

First, the pixel-based reconstruction results of a cardiac pacemaker battery using just a few projections were presented, which were turned into a 3-dimensional visualization. With this model, the author could satisfactorily visualize the intrinsic electrically charged part, which was the goal of the examination.

Next, the author presented the reconstruction of a boron-carbide control rod of an atomic reactor. The task was to identify possible helium accumulations in the lower section of the rod, which became clearly visible in the volume-rendered 

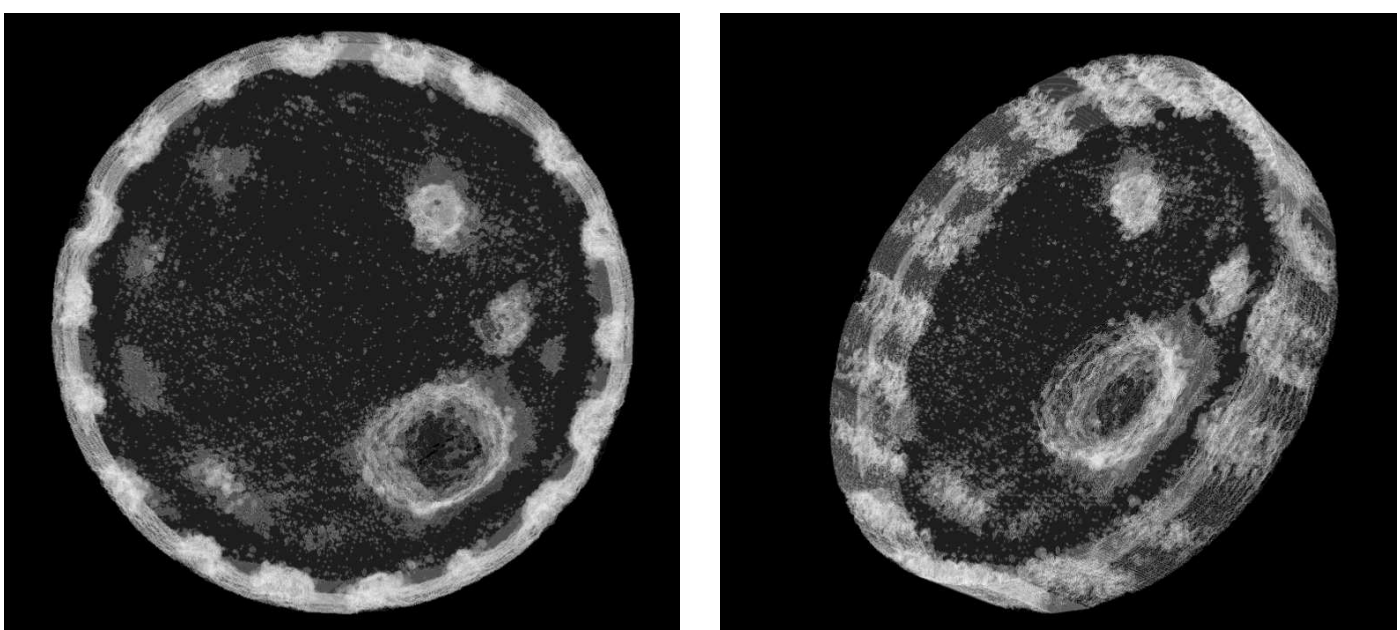

Figure 6.9: Two different volume-rendered views of cross-sections from 2451 to 2550. The slices were reconstructed by the DT technique from 9 projections using 256 intensity levels.

model of the object. This provided persuasive proof for the physicists and justified their original suspicions. 



\section{Chapter 7}

\section{The DIRECT framework}

DIRECT is the abbreviation for DIscrete REConstruction Techniques, which was first published in [53]. It is a programming system designed to provide a consistent framework for implementing, comparing, and evaluating reconstruction algorithms used in discrete tomography. A number of reconstructions, as well as the pixelbased DT technique, were incorporated and the users can integrate additional methods into the system. The aim is not only to give a set of reconstruction algorithms, but also to provide a tool for

- phantom generation,

- projection generation,

- image reconstruction,

- evaluation,

- and visualization.

All these components use a common file format for parameter specification as well as data representation. Each component can be applied separately, but the framework allows the user to carry out complex experiments. Such experiments make it possible to run different reconstruction methods on the same projection data or to apply the same method with different parameters. With this, the user can create instruction files containing control commands for the system, which execute the specified components with the given parameters. The input data and the results are located in so-called data files.

Figure 7.1 shows how the DIRECT files and the components are related to each other. Each component is controlled by the DIRECT core program, which drives the components by virtue of the instruction file and passes the DIRECT data file to the various components. The components are responsible for interpreting the input data file and extending it with a phase output, as shown in Table 7.1.

The intention was to design a simple, easy-to-adapt, and loosely coupled set of pluggable components, where the system provides a built-in implementation of each module, but allows the replacement of any of them. The pixel-based DT 


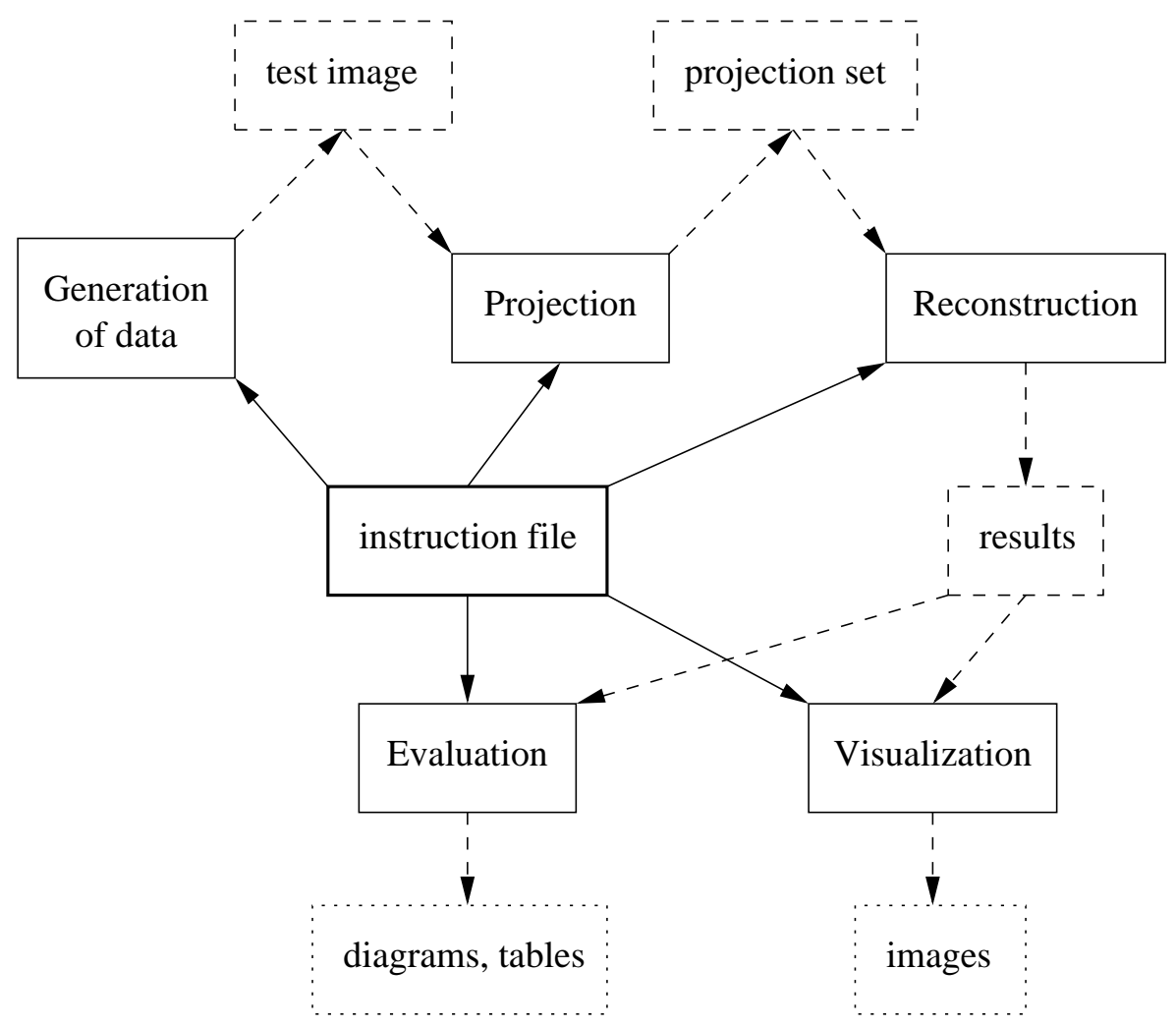

Figure 7.1: The scheme of the DIRECT framework. Solid boxes - components, dashed boxes - data files, dotted boxes - other data artifacts. Solid lines represent the control flow, while dashed lines denote the data flow. Source: [53].

\begin{tabular}{lcc}
\hline Component & Component input & Component output \\
\hline phantom generation & phantom parameters & generated phantom image \\
projection & proj. parameters, orig. image & generated projections \\
image reconstruction & projections & reconstructed image \\
visualization & reconstructed image & displayable image \\
evaluation & reconstructed and orig. images & statistics \\
\hline
\end{tabular}

Table 7.1: The input and output data of DIRECT the components.

method used custom implementations for the parallel projection generator, evaluation, and reconstruction components, but it extensively utilized the DIRECT data file format for inter-component communication.

\subsection{DIRECT data files}

The DIRECT data file provides a common file interface between the components described in Figure 7.1 and has the XML (Extensible Markup Language) [4] format with a prescribed structure. It can contain three kinds of nodes, namely discrete 
images, projection sets, and some additional information. With this format one can store images and projections flexibly in different data type representations like integer, float, word, byte, $\beta$-representation [16], or in an external file of an arbitrary user defined format. In the latter case, the user has the freedom to implement and join custom file readers and writers. Besides numerical data, the DIRECT format allows one to add meta information or comments referring to, for example, the conditions of data acquisition and the name of the object the projections are made from.

Three snippets of a sample DIRECT file are given in listings 7.1, 7.2, and 7.3. The first listing stores a $5 \times 5$ (ncols and nrows attributes) binary digital image, where each pixel is represented by an integer (datatype attribute).

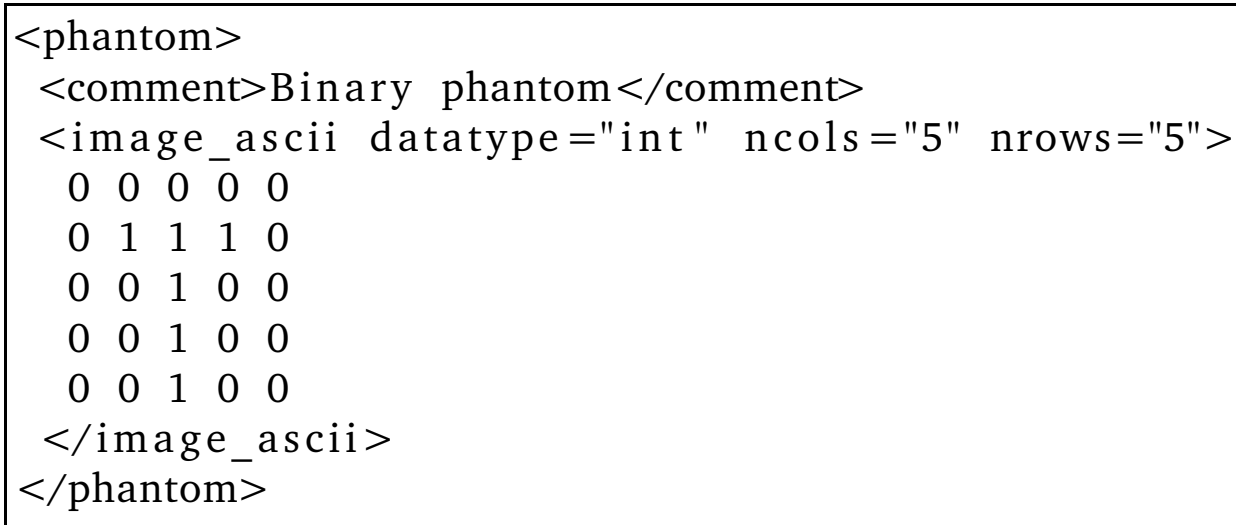

Listing 7.1: A binary phantom image represented in the DIRECT format.

The XML code seen in Listing 7.2 contains the $0^{\circ}$ and $90^{\circ}$ (angle attributes) projections of the phantom found in Listing 7.1. The projections were produced using 10 projection lines (ncols attribute) represented as integers, where each value is calculated as a line sum (type attribute). Here ddist and dwidth record the distance between two neighbouring detectors and the width of a single detector. These attributes play an important role, especially when the projections are real physical measurements.

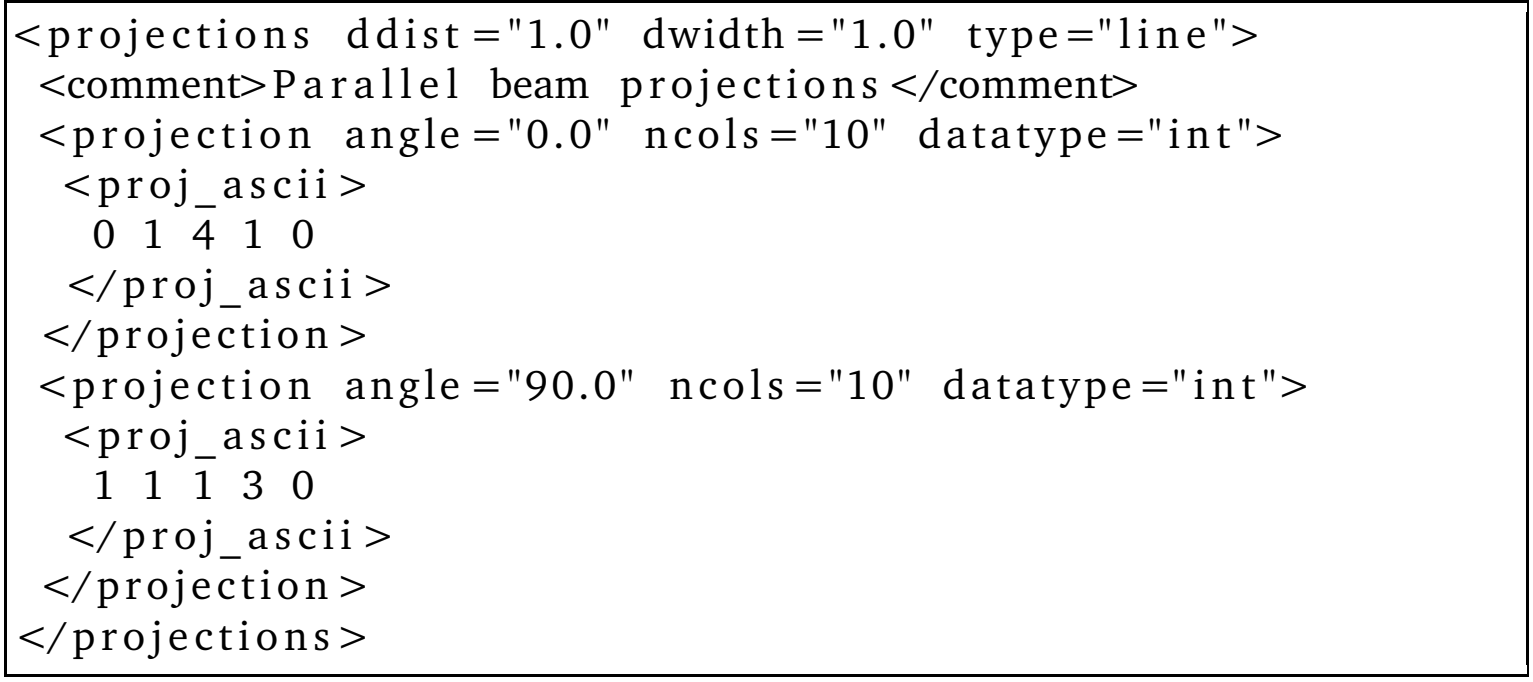

Listing 7.2: DIRECT representation of two natural projections of the phantom image represented in Listing 7.1. 
Finally, Listing 7.3 is one of the possible reconstruction results produced after 150000 iterations (niter attribute) by the pixel-based reconstruction technique. In order to allow the comparison of results based on different parameter set-ups, <method> allows one to link the input parameters of the reconstruction to the $\langle$ reconstruction $\rangle$ node.

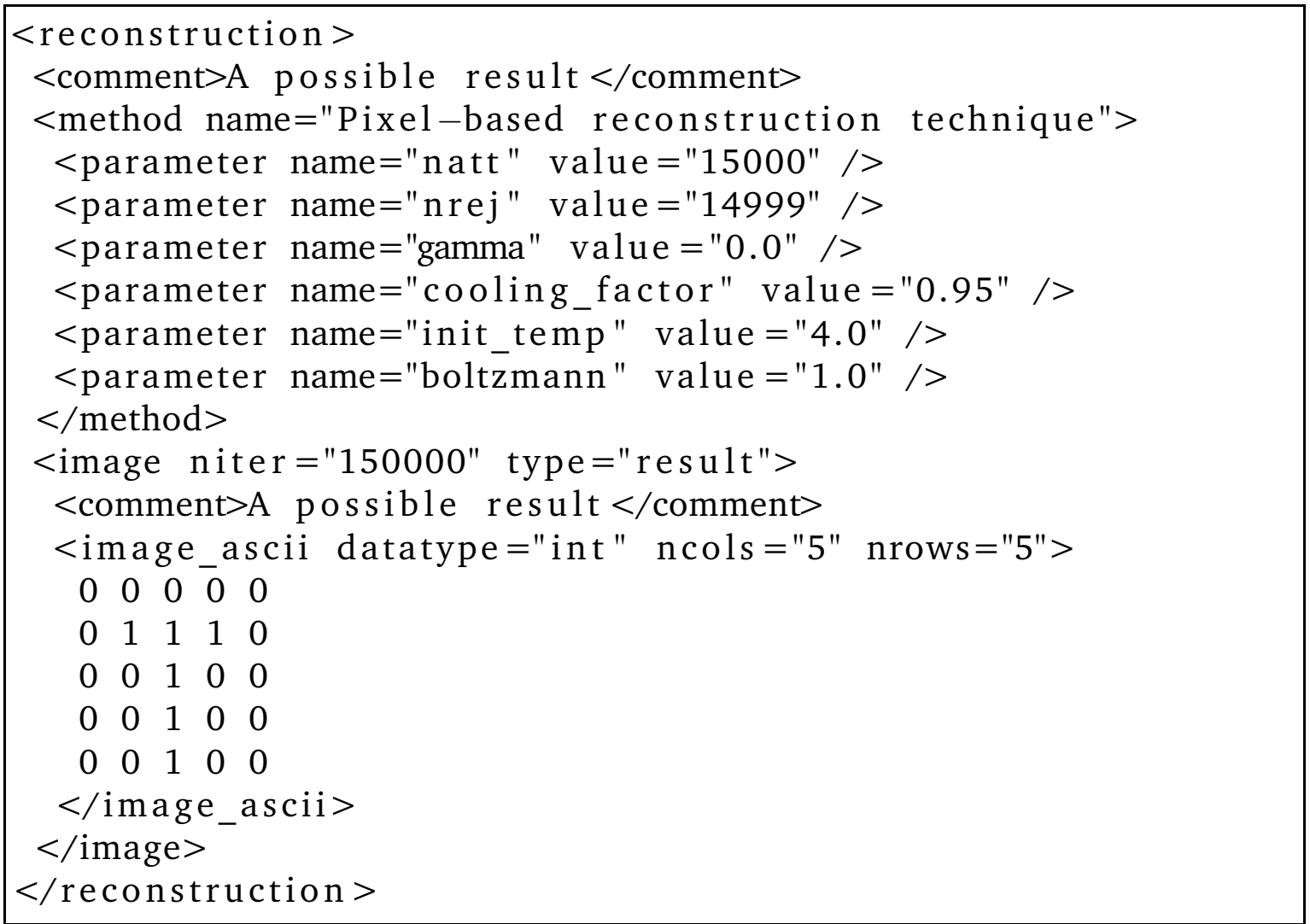

Listing 7.3: DIRECT representation of a reconstruction got from the projections presented in Listing 7.2.

Since the DIRECT file must conform with a strict structure determined by the format description, before processing the file users should check whether the XML is a valid and well-formatted DIRECT file. This check can be accomplished by applying another tool of the XML technology. The format is specified by an XSD (XML Schema Definition) [9] file defining the grammar of DIRECT files.

A DIRECT file can become very large, hence the manual extraction of the information contained may be quite problematic. To make things easier, an XSL/XSLT (Extensible Stylesheet Language/Transformation) [5] was implemented, which facilitates the conversion of an XML to any other XML-based format. The basic variant of DIRECT XLS/XSLT is prepared to turn the DIRECT data representation into an HTML file, and to furnish a visual representation in a Web browser, as shown in Figure 7.2. However, this kind of visualization cannot display image objects of arbitrary representations stored in the data files. To overcome this problem, the author implemented a PGM [64] writer to display 2-dimensional image matrices in a lossless displayable format. Hence all reconstructions depicted in this thesis are 256-level PGM P5 images. 


\subsection{DIRECT instruction files}

As mentioned previously, DIRECT comprises several components, which were implemented in separate programs. In order to standardize how the user specifies the data and parameters for any of the programs managed by the DIRECT system, some control commands were introduced. These commands can be placed in an instruction file [53] having the XML format, which is executed by the DIRECT framework.

During the execution of an instruction sequence, several data files can be created by the different applications. However, when a component seeks to extend a file, which was already created by another component, the principle of file handling is that the data files can only be appended and no modification is allowed. This rule helps to preserve the consistency between data objects.

\subsection{The Web interface}

As well as the discrete tomographic techniques being developed at the Department of Image Processing and Computer Graphics at the University of Szeged, the pixelbased method was also integrated within the DIRECT framework and published via the uniform Web interface available at [3]. The Web interface allows the visitor to generate projections, execute reconstructions, visualize the results, and display statistics. The following reconstruction techniques were made available and can be tested online:

- The reconstruction of hv-convex connected discrete sets [15].

- The reconstruction of hv-convex discrete sets with absorption [49].

- The parametric reconstruction of binary circular objects [55].

- The pixel-based reconstruction of binary images [55].

For more details on the DIRECT framework, see [3] and [53].

\subsection{Summary}

This chapter gave a general overview of the DIRECT system, which provides a programming environment for DT techniques. It described the data file format that was utilized by the author as well, and the instruction files designed to perform complex experiments. 


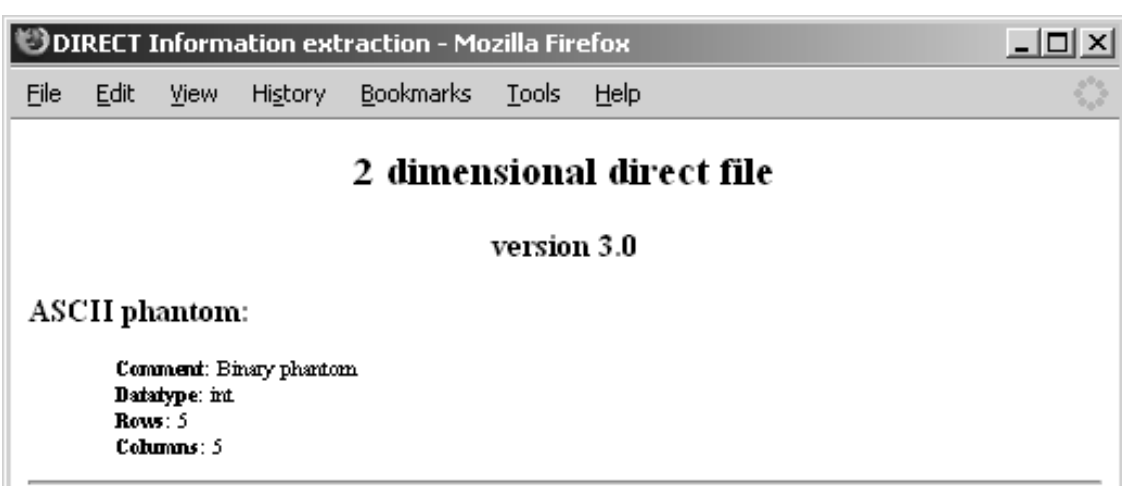

Projections:

Comment: Parallel beam projections

Detertor uidth: 1.0

Detertor distance: 1.0

Type of projections: line

Projection list:

Angle Sire Datatype Location

\begin{tabular}{|l|l|l|l|l|l|l|l|l|l|}
\hline 0.0 & 10 & int & Fitemal \\
\hline
\end{tabular}

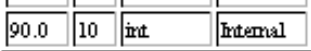

\section{Reconstruction:}

Comment: A possible result

Name of the generating meihod: Pixel-based reconstruction method

Parameters:

\begin{tabular}{|l|l|}
\hline \multicolumn{1}{|c|}{ Name } & Vahue \\
\hline \hline rast & 15000 \\
\hline \hline rarej & 14999 \\
\hline gamma & 0.0 \\
\hline temm_factor & 0.95 \\
\hline init_temp & 4.0 \\
\hline boltomarn & 1.0 \\
\hline
\end{tabular}

Image list:

\begin{tabular}{|l|l|l|l|l|l|l|l|l|}
\hline Type & $\begin{array}{c}\text { Number of } \\
\text { iterations }\end{array}$ & Rows & Columm & Datatype & Location & Foumat & Comment \\
\hline \hline Tesult & 150000 & 5 & 5 & irt & Frtemal & & $\begin{array}{l}\text { A possible } \\
\text { result }\end{array}$ \\
\hline
\end{tabular}

Figure 7.2: Content of a DIRECT data file displayed via XSL/XSLT. 


\section{Chapter 8}

\section{General summary}

DT is a relatively new field of image processing and it does not yet have many real applications. Hence, the goal of the research work described in this thesis was to devise a new pixel-based DT technique that is suitable for the reconstruction of objects comprising a small number of homogeneous materials, and where just a few projections are available. The new pixel-based DT technique introduced in Section 2.3 produces the reconstruction result by minimizing an objective functional, where the stochastic simulated annealing was applied as an optimizer.

First, in Chapter 3, the author tested the capabilities of the technique on binary and multi-level software phantoms using noisy and noiseless projection images. As the reconstruction of multi-level images and the reconstruction using noisy projections both result in similarly degraded images, a smoothness a priori was incorporated into the reconstruction model. Although the regularized results sometimes merged adjacent object parts, it did yield an improved reconstruction quality.

The experience gained from varying parameters within reasonable changes in the simulation tests made it possible to effectively apply the technique to real physical measurements. However, the projection images were corrupted by some distorting effects, which needed to be handled before performing a reconstruction. Hence, the author supplied a possible set of pre-processing steps and demonstrated their benefits on the projections and reconstructions of a VIDICON tube in Chapter 4.

In Chapter 5 the author tested the pixel-based technique on three physical phantoms. Overall, it can be said that, after the execution of the necessary pre-processing steps, the pixel-based DT method can produce acceptable reconstruction results, even if the classical ones fail when there is a small number $(\leq 10)$ of projections. Under such circumstances, the DT technique reflects the real absorption values better than FBP and ART do, because it cannot show false intensity levels. This fact gives the pixel-based technique an advantage, especially for 3-dimensional visualizations, when ART and FBP do not perform well.

It was also of interest to learn how the pixel-based method would perform when the object was made of a few materials, but their perfect homogeneity could not be assured. For this purpose, the author was supplied with the projections of two real (non-reference) objects. The first object was a cardiac pacemaker battery, where the aim was to see whether the intrinsic part, containing the electrically charged material, had a highly irregular distribution. The second object was a boron-carbide 
control rod of an atomic reactor. Here the task was to identify possible helium accumulations in the lower section of the rod. In both cases, the author successfully applied the extended version of the pixel-based method (using 256 intensity levels), and the 3-dimensional models constructed from the reconstructed images and presented in Chapter 6 clearly confirm one's suspicions even when only 1020 projections were available for the reconstructions. Lastly, Chapter 7 described the DIRECT programming environment that the pixel-based method was integrated into, and within which the above examinations were performed.

There are still a number of open questions to be addressed concerning how the method might be further improved. A general approach should be found to determine a good regularization coefficient based on the input data and parameters. The method should be extended by an edge preserving technique so as to avoid the replacement of borders of neighbouring regions by intermediary intensities. Yet another issue is how the problem of inconsistency to improve the reconstruction quality should best be handled. Lastly, as there is an apparent connection between DT and image segmentation, it would be interesting to see whether some techniques in segmentation could be adapted and applied in DT procedures. 


\section{Appendix A}

\section{Noisy binary reconstructions}

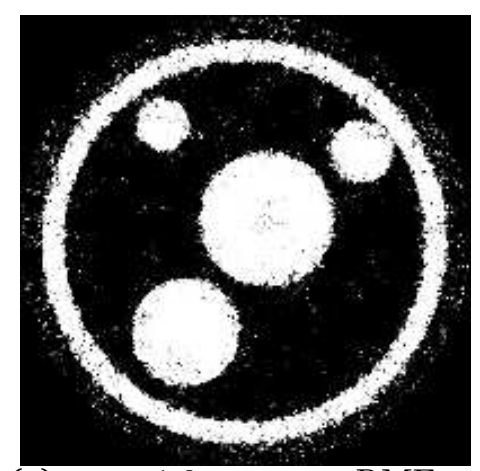

(a) $\gamma=1.0$, average $\mathrm{RME}=$ 14.1766.

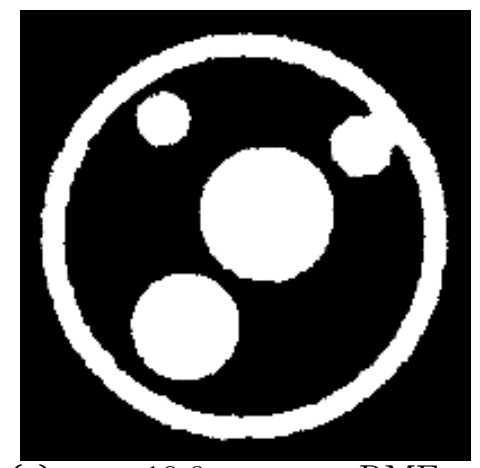

(c) $\gamma=10.0$, average $\mathrm{RME}=$ 3.4694 .

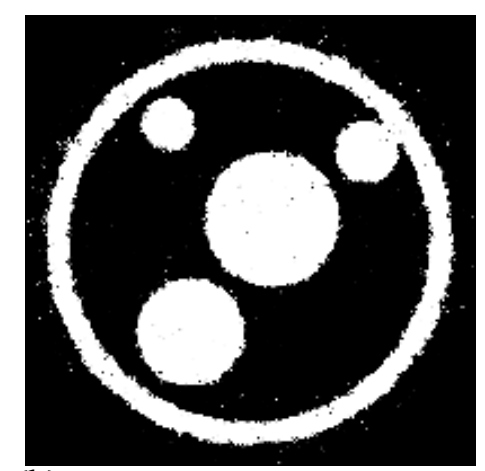

(b) $\gamma=4.0$, average $\mathrm{RME}=$ 6.8144 .

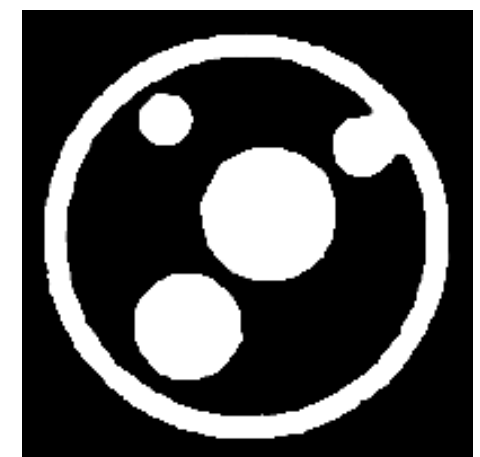

(d) $\gamma=20.0$, average $\mathrm{RME}=$ 3.0058 .

Figure A.1: Average reconstruction results of circles from $\sigma=10$ noisy projections obtained using the pixel-based method (16 projections, 400 measurements/projection). 


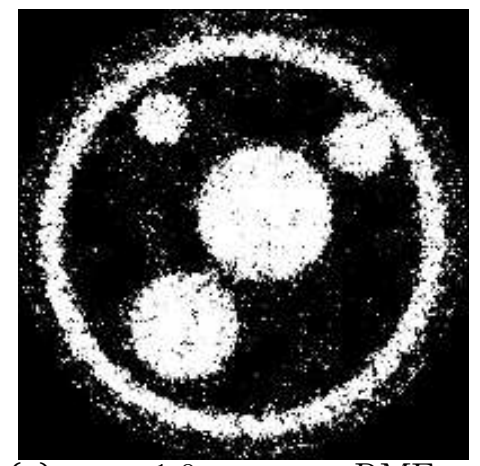

(a) $\gamma=1.0$, average $\mathrm{RME}=$ 25.2875 .

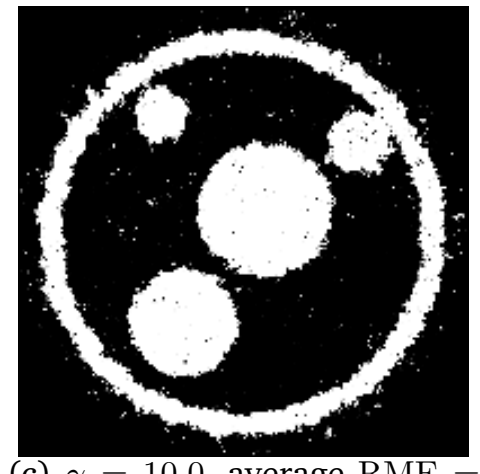

(c) $\gamma=10.0$, average RME $=$ 6.8582 .

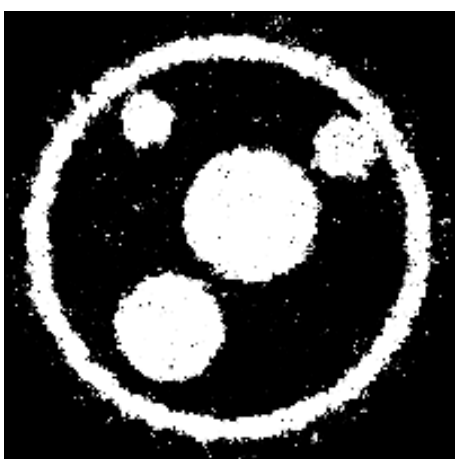

(b) $\gamma=4.0$, average $\mathrm{RME}=$ 12.9536 .

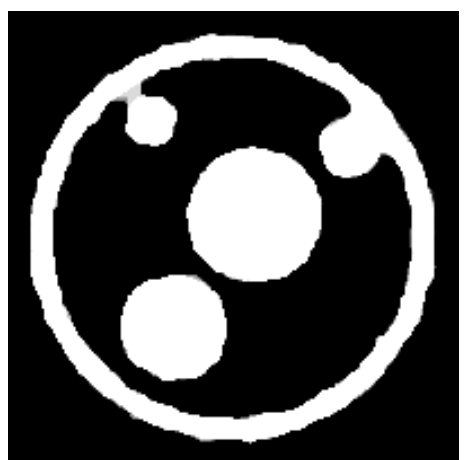

(d) $\gamma=20.0$, average RME $=$ 5.8013 .

Figure A.2: Average reconstruction results of circles from $\sigma=40$ noisy projections obtained using the pixel-based method (16 projections, 400 measurements/projection). 


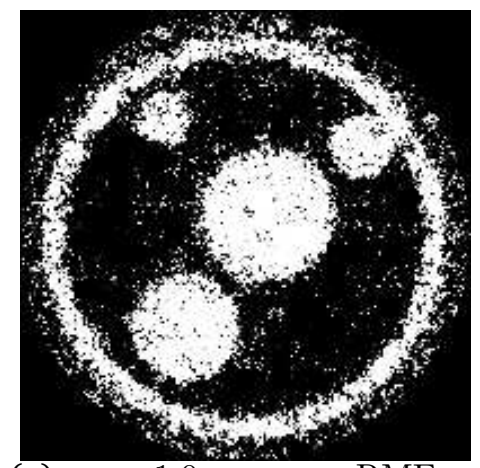

(a) $\gamma=1.0$, average $\mathrm{RME}=$ 36.0315 .

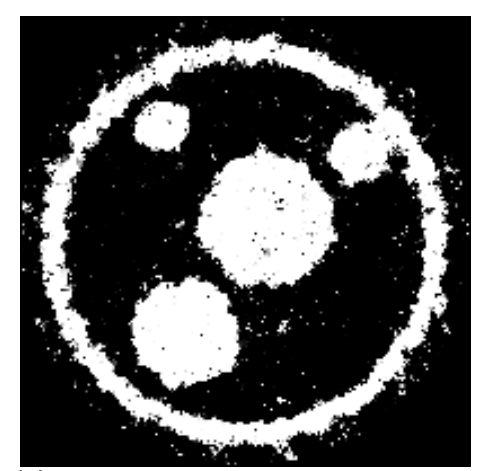

(c) $\gamma=10.0$, average $\mathrm{RME}=$ 10.4659 .

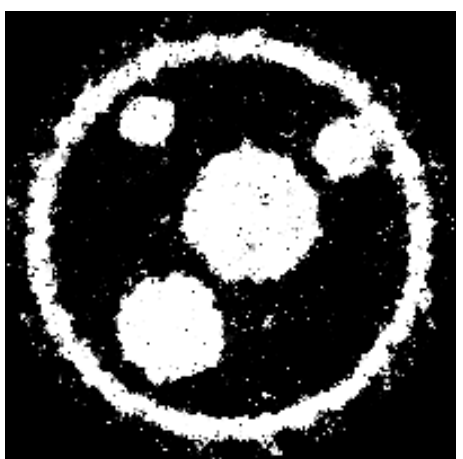

(b) $\gamma=4.0$, average RME $=$ 18.4101 .

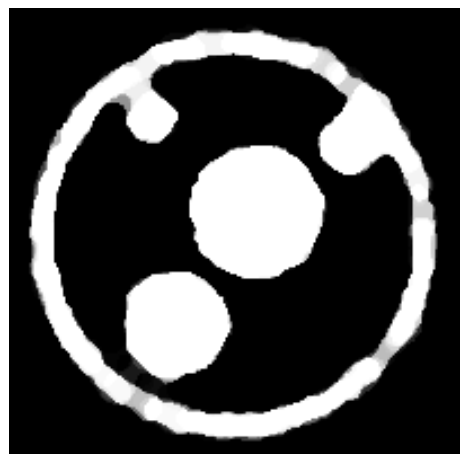

(d) $\gamma=20.0$, average $\mathrm{RME}=$ 10.5076 .

Figure A.3: Average reconstruction results of circles from $\sigma=100$ noisy projections obtained using the pixel-based method (16 projections, 400 measurements/projection). 



\section{Appendix B}

\section{Noisy multi-level reconstructions}

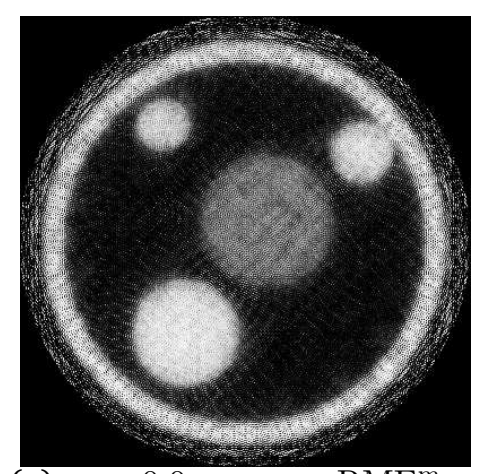

(a) $\gamma=0.0$, average $\mathrm{RME}^{\mathrm{m}}=$ 63.5219 .

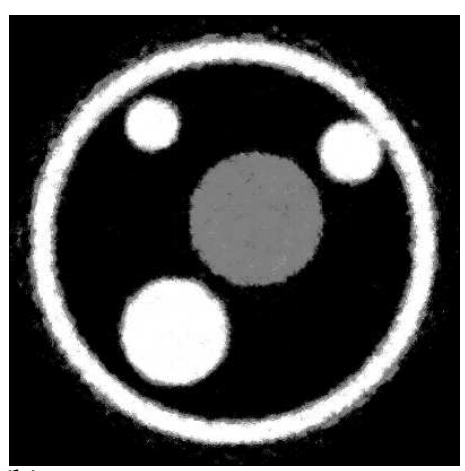

(b) $\gamma=2.0$, average $\mathrm{RME}^{\mathrm{m}}=$ 14.4316 .

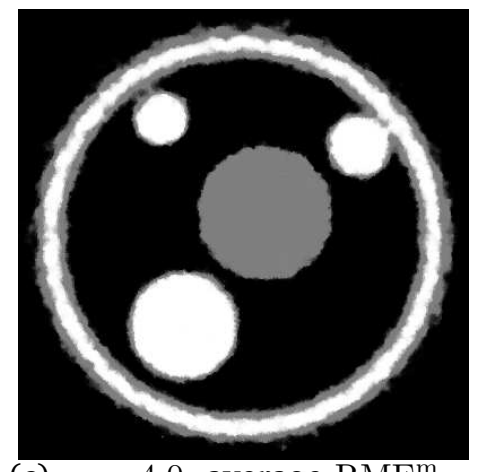

(c) $\gamma=4.0$, average $\mathrm{RME}^{\mathrm{m}}=$ 22.6173 .

Figure B.1: Average reconstruction results of circles from $\sigma=5$ noisy projections obtained using the pixel-based method (16 projections, 400 measurements/projection). 


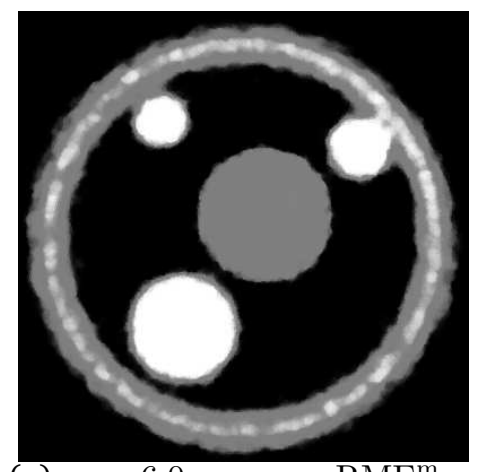

(a) $\gamma=6.0$, average $\mathrm{RME}^{\mathrm{m}}=$ 22.6173 .

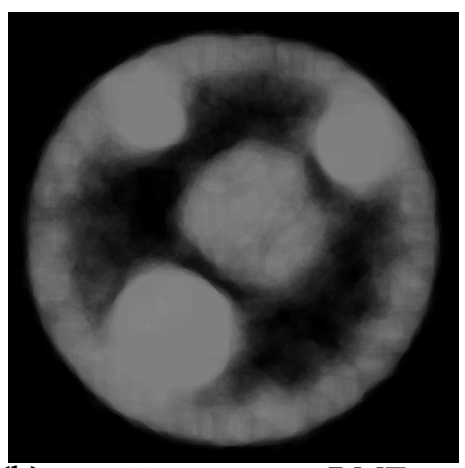

(b) $\gamma=20.0$, average $\mathrm{RME}^{\mathrm{m}}=$ 84.7240 .

Figure B.1: (Cont.) Average reconstruction results of circles from $\sigma=5$ noisy projections obtained using the pixel-based method (16 projections, 400 measurements/projection). 


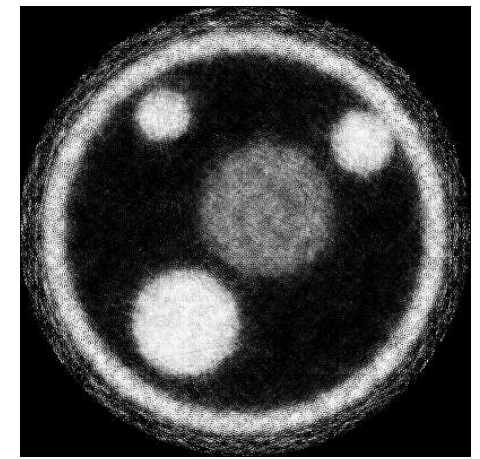

(a) $\gamma=0.0$, average $\mathrm{RME}^{\mathrm{m}}=$ 66.2146 .

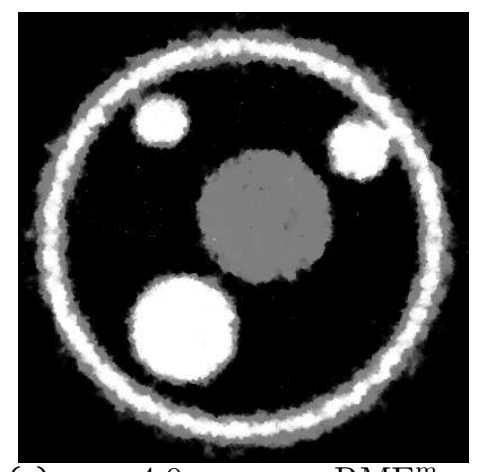

(c) $\gamma=4.0$, average $\mathrm{RME}^{\mathrm{m}}=$ 25.3682 .

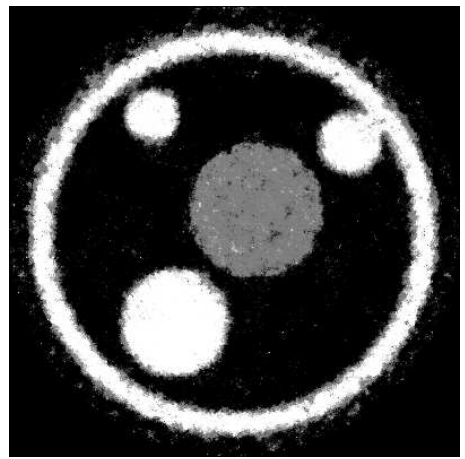

(b) $\gamma=2.0$, average $\mathrm{RME}^{\mathrm{m}}=$ 18.5684 .

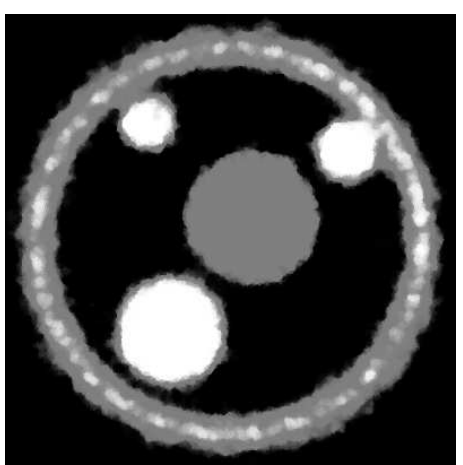

(d) $\gamma=6.0$, average $\mathrm{RME}^{\mathrm{m}}=$ 44.3227 .

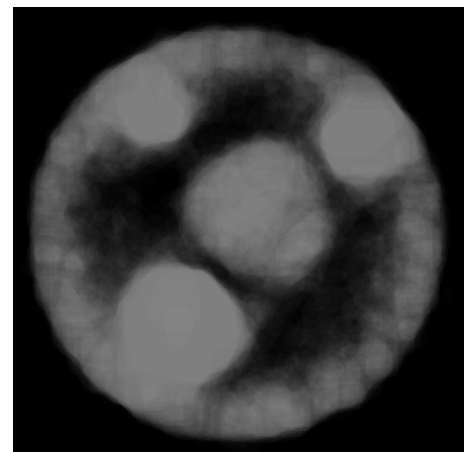

(e) $\gamma=20.0$, average $\mathrm{RME}^{\mathrm{m}}=$ 86.4631 .

Figure B.2: Average reconstruction results of circles from $\sigma=30$ noisy projections obtained using the pixel-based method (16 projections, 400 measurements/projection). 



\title{
Appendix C
}

\section{SNARK command files}

\author{
PICTURE RECONSTRUCTION 1551.0 \\ PROJECTION REAL \\ EXECUTE CONVOLUTION \\ Experimental reference_cylinder \\ COSINE $0.5 \quad 3$ \\ END
}

Listing C.1: SNARK93 command file used for the FBP reconstructions of the Plexiglas reference cylinder.

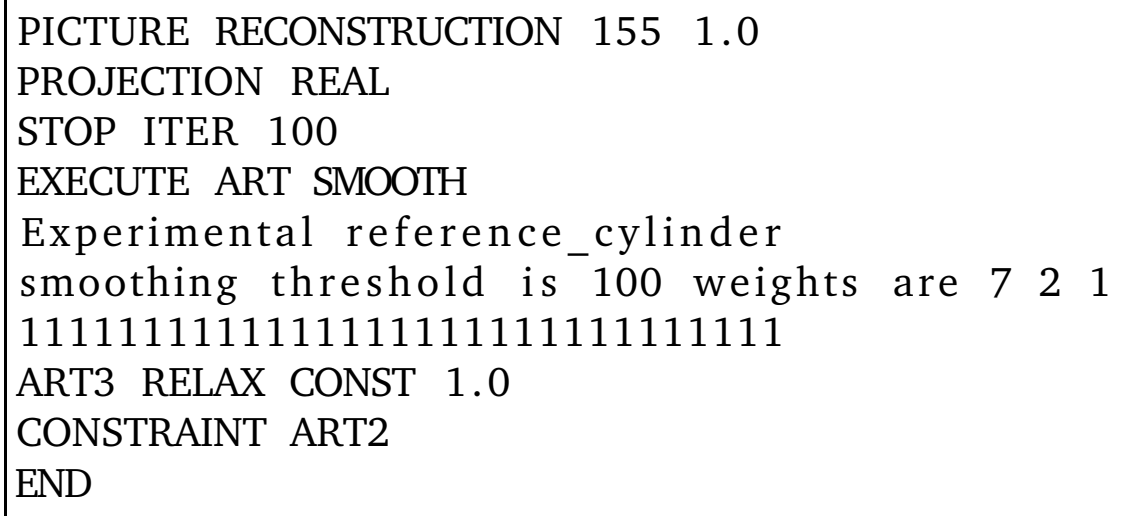

Listing C.2: SNARK93 command file used for the ART reconstructions of the Plexiglas reference cylinder. 



\section{Bibliography}

[1] 3D Slicer. http://www.slicer.org.

[2] DICOM - Digital Imaging and Communications in Medicine. http://medical. nema.org.

[3] The DIRECT framework. http://www.inf.u-szeged.hu/direct.

[4] Extensible markup language (XML). http://www.w3.org/XML.

[5] The extensible stylesheet language family (XSL). http://www.w3.org/Style/ XSL.

[6] PeakFit. http://www. sigmaplot.com.

[7] The SNARK reconstruction system. http://www. snark05.com.

[8] SPSS Statistics. http://www.spss.com.

[9] XML Schema Part 0: Primer Second Edition. http://www.w3.org/TR/ xmlschema- 0 .

[10] A. H. Andersen and A. C. Kak. Simultaneous algebraic reconstruction technique (sart). Ultrason. Img., 6:81-94, 1984.

[11] M. Balaskó, A. Kuba, A. Nagy, Z. Kiss, L. Rodek, and L. Ruskó. Neutron-, gamma- and X-ray three-dimensional computed tomography at the Budapest research reactor site. Nuclear Instruments and Methods in Physics Research A, 542:22-27, 2005.

[12] M. Balaskó, A. Kuba, A. Tanács, Z. Kiss, A. Nagy, and B. Schillinger. Comparison Radiography and Tomography Possibilities of FRM-II (20 MW) and Budapest (10 MW) Research Reactor. In Proceedings of the Eighth World Conference WCNR-8, pages 18-27, 2008.

[13] M. Balaskó, E. Sváb, Z. Kiss, A. Tanács, A. Nagy, and A. Kuba. Study of the inner structure of a damaged control rod by neutron and X-ray radiography and discrete tomography. In Proceedings of the Eighth World Conference WCNR8, pages 294-303, 2008. 
[14] M. Balaskó, E. Sváb, A. Kuba, Z. Kiss, L. Rodek, and A. Nagy. Pipe corrosion and deposit study using neutron- and gamma- radiation sources. Nuclear Instruments and Methods in Physics Research A, 542:302-308, 2005.

[15] E. Balogh, A. Kuba, Cs. Dévényi, and A. Del Lungo. Comparison of algorithms for reconstructing hv-convex discrete sets. Linear Algebra and Its Applications, 339:23-35, 2001.

[16] E. Barucci, A. Frosini, A. Kuba, A. Nagy, S. Rinaldi, M. Samal, and S. Zopf. Emission Discrete Tomography in [37], pages 333-366. Birkhäuser, Boston, 1999.

[17] J. Baumann, Z. Kiss, S. Krimmel, A. Kuba, A. Nagy, L. Rodek, B. Schillinger, and S. Juergen. Discrete tomography methods for non-destructive testing in [37], pages 303-332. Birkhäuser, Boston, 2007.

[18] R. Bracewell. Convolution Theorem in [19], pages 108-112. McGraw-Hill, New York, 1999.

[19] R. Bracewell. The Fourier Transform and Its Applications, 3rd ed. McGraw-Hill, New York, 1999.

[20] L. G. Brown. A survey of image registration techniques. ACM Computing Surveys, 24:325-376, 1992.

[21] M. T. Chan, G. T. Herman, and E. Levitan. Probabilistic Modeling of Discrete Images in [35], pages 213-235. Birkhäuser, Boston, 1999.

[22] A. P. Dempster, N. M. Laird, and D. B. Rubin. Maximum likelihood from incomplete data via the EM algorithm. Journal of the Royal Statistical Society, 39(Series B):1-38, 1977.

[23] T. A. Feo and M. G. C. Resende. Greedy randomized adaptive search procedures. Journal of Global Optimization, 6:109-133, 1995.

[24] R. A. Fisher. On an absolute criterion for fitting frequency curves. Messenger of Mathematics, 41:155-160, 1912.

[25] T. Frese, C. A. Bouman, and K. Sauer. Multiscale Bayesian Methods for Discrete Tomography in [35], pages 237-264. Birkhäuser, Boston, 1999.

[26] R. J. Gardner and P. Gritzmann. Discrete tomography: Determinations of finite sets by X-rays. Trans. Amer. Math. Soc., 349:2271-3395, 1997.

[27] R. J. Gardner and P. Gritzmann. Uniqueness and complexity in discrete tomography in [35], pages 3-34. Birkhäuser, Boston, 1999.

[28] R. J. Gardner and P. McMullen. On Hammer's X-ray problem. J. London Math. Soc., 21:171-175, 1980. 
[29] S. Geman and D. Geman. Stochastic relaxation, Gibbs distributions, and the Bayesian restoration of images. IEEE Trans. on PAMI, 6:721-741, 1984.

[30] P. Gilbert. Iterative methods for the three-dimensional reconstruction of an object from projections. J. Theor. Biol., 6:105-117, 1972.

[31] D. E. Goldberg. Genetic Algorithms in Search, Optimization and Machine Learning, Kluwer Academic Publishers. Kluwer Academic Publishers, Boston, 1989.

[32] R. Gordon, R. Bender, and G. T. Herman. Algebraic reconstruction techniques (ART) for three-dimensional electron microscopy and X-ray photography. Journal of Theoretical Biology, 29:471-481, 1970.

[33] G. T. Herman. Image Reconstruction from Projections. Academic Press, Boston, 1980.

[34] G. T. Herman, M. Chan, Y. Censor, E. Levitan, R. M. Lewitt, and T. K. Narayan. Maximum a posteriori image reconstruction from projections in [57], pages 5389. Springer-Verlag, New York, 1996.

[35] G. T. Herman and A. Kuba, editors. Discrete Tomography. Foundations, Algorithms, and Applications. Birkhäuser, Boston, 1999.

[36] G. T. Herman and A. Kuba. Discrete tomography in medical imaging. Proceedings of the IEEE, 91(2):1612-1626, 2003.

[37] G. T. Herman and A. Kuba, editors. Advances in discrete tomography and its applications. Birkhäuser, Boston, 2007.

[38] S. Kaczmarz. Angenaherte Auflösung von Systemen linearer Gleichungen. Bull. Acad. Pol. Sci. Lett. A, 6-8A:355-357, 1937.

[39] A. C. Kak and M. Slaney. Principles of Computerized Tomographic Imaging. Society for Industrial and Applied Mathematics, 2001.

[40] A. Kaneko and L. Huang. Reconstruction of plane figures from two projections in [35], pages 115-135. Birkhäuser, Boston, 1999.

[41] S. Kirkpatrick, C. D. Gelatt, and M. P. Vecchi. Optimization by simulated annealing. Science, 220:671-680, 1983.

[42] Z. Kiss, L. Rodek, and A. Kuba. Image reconstruction and correction methods in neutron and X-ray tomography. Acta Cybernetica, 17:557-587, 2006.

[43] Z. Kiss, L. Rodek, A. Nagy, A. Kuba, and M. Balaskó. Reconstruction of pixelbased and geometric objects by discrete tomography. Simulation and physical experiments. Electronic Notes in Discrete Mathematics, 20:475-491, 2005.

[44] T. Y. Kong and G. T. Herman. Tomographic equivalence and switching operations in [35], pages 3-34. Birkhäuser, Boston, 1999. 
[45] S. Krimmel, J. Baumann, Z. Kiss, A. Kuba, A. Nagy, and J. Stephan. Discrete tomography for reconstruction from limited view angles in non-destructive testing. Electronic Notes in Discrete Mathematics, 20:455-474, 2005.

[46] A. Kuba. Reconstruction of two-directionally connected binary patterns from their two orthogonal projections. Comp. Vision Graph. and Image Proc., 27:249-265, 1984.

[47] A. Kuba and G. T. Herman. Discrete Tomography: A historical overview in [35], pages 3-34. Birkhäuser, Boston, 1999.

[48] A. Kuba and A. Nagy. Reconstruction of hv-convex binary matrices from their absorbed projections. Electronic Notes in Theoretical Computer Science, 46:1$10,2001$.

[49] A. Kuba, A. Nagy, and E. Balogh. Reconstructing hv-convex binary matrices from their absorbed projections. Discrete Applied Mathematics (Special Issue), 139:137-148, 2004.

[50] A. Kuba and M. Nivat. Reconstruction of discrete sets with absorption. Linear Algebra and Its Applications, 339:171-194, 2001.

[51] A. Kuba, L. G. Nyúl, and K. Palágyi, editors. Discrete Geometry for Computer Imagery, 13th International Conference, DGCI 2006, Szeged, Hungary, October 25-27, 2006, Proceedings, volume 4245 of Lecture Notes in Computer Science. Springer, 2006.

[52] A. Kuba, L. Rodek, Z. Kiss, L. Ruskó, A. Nagy, and M. Balaskó. Discrete tomography in neutron radiography. Nuclear Instruments and Methods in Physics Research A, 542:376-382, 2005.

[53] A. Kuba, L. Ruskó, Z. Kiss, and A. Nagy. Discrete reconstruction techniques. Electronic Notes in Discrete Mathematics, 20:385-398, 2005.

[54] A. Kuba, L. Ruskó, L. Rodek, and Z. Kiss. Application of Discrete Tomography in Neutron Imaging. In Proceedings of the Seventh World Conference WCNR-7, pages 361-371, 2002.

[55] A. Kuba, L. Ruskó, L. Rodek, and Z. Kiss. Preliminary studies of discrete tomography in neutron imaging. IEEE Trans. Nucl. Sci., 52:380-385, 2005.

[56] Á. Kurusa. The radon transform on half sphere. Acta Sci. Math., 58:143-158, 1993.

[57] S. E. Levinson and L. Shepp, editors. Image Models (and their Speech Model Cousins). Springer-Verlag, New York, 1996.

[58] E. Levitan and G. T. Herman. A maximum a posteriori probability expectation maximization for image reconstruction in emission tomography. IEEE Trans. on Medical Imaging, 6:185-192, 1987. 
[59] G. G. Lorentz. A problem of plane measure. Amer. J. Math., 71:417-426, 1949.

[60] S. Matej, A. Vardi, G. T. Herman, and E. Vardi. Binary Tomography Using Gibbs Priors in [35], pages 191-212. Birkhäuser, Boston, 1999.

[61] N. Metropolis, A. Rosenbluth, M. Rosenbluth, A. Teller, and E. Teller. Equation of state calculation by fast computing machines. J. Chem. Phys., 21:10871092, 1953.

[62] A. Nagy and A. Kuba. Reconstruction of binary matrices from fan-beam projections. Acta Cybernetica, 17(2):359-385, 2005.

[63] A. Nagy and A. Kuba. Parameter settings for reconstructing binary matrices from fan-beam projections. Journal of Computing and Information Technology, 14:101-110, 2006.

[64] J. Poskanzer. Description of the Portable Gray Map (PGM) format. http: //netpbm.sourceforge.net/doc/pgm.html, 1989, 1991.

[65] J. Radon. Über die bestimmung von funktionen durch ihre integralwerte längs gewisser manningfaltigkeiten. Ber. Vehr. Sächs. Akad. Wiss. Leipzig Math. Phys. Kl., 69:262-277, 1917.

[66] N. Robert, F. Peyrin, and M. J. Yaffe. Binary vascular reconstruction from a limited number of cone beam projections. Medical Physics, 21:1839-1851, 1994.

[67] H. J. Ryser. Combinatorial properties of matrices of zeros and ones. Canad. J. Math, 9:371-377, 1957.

[68] L. Shepp and Y. Vardi. Maximum likelihood reconstruction in emission tomography. IEEE Trans. on Medical Imaging, 1:113-121, 1982.

[69] A. Tanács and A. Kuba. Evaluation of a fully automatic medical image registration algorithm based on mutual information. Acta Cybernetica, 16:327-336, 2003.

[70] M. J. M. van Laarhoven and E. H. L. Aarts. Simulated Annealing: Theory and Applications. D. Reidel Publishing Company, Dordrecht, Holland, 1987.

[71] S. Weber, A. Nagy, T. Schüle, C. Schnörr, and A. Kuba. A benchmark evaluation of large-scale optimization approaches to binary tomography. In DGCI, pages 146-156, 2006. 



\section{Summary in English}

Discrete tomography is a relatively new area of image processing, and does not yet have many physical applications. So the goal of the study was to develop a new pixel-based DT reconstruction method designed for the reconstruction of industrial objects (usually made of a few materials) from a small number of projections.

\section{Simulation studies}

After the elaboration of the theoretical background and the reconstruction technique, the author investigated the behaviour of the method by simulating the ideal and simplest conditions, where the projections were noiseless and the object to be reconstructed was a binary image. The most important task was to gain some experience with the parameterization of the SA optimizer, estimate the initial range of the annealing parameters, and elaborate a suitable annealing schedule. Otherwise, the improper choice of any of the parameters could allow the method to needlessly run for a very long time or get stuck in a local minimum and terminate prematurely. However, a careful choice of parameter values almost always led to good results.

In order to mimic the real-life physical conditions, a statistical noise model was developed and incorporated into the simulation environment to distort the projections by additive Gaussian noise. Under noisy conditions, the projections usually become inconsistent and perfect results (where the objective takes 0) cannot be expected. To improve the corrupted reconstructions, the objective functional was supplemented by a regularization term, which incorporated a priori information, preferring the homogeneous regions to non-homogeneous areas. This is the usual case for industrial objects just made of a few materials. Furthermore, the author introduced a possible extension to enable the reconstruction of images containing more than two intensity levels.

The author published his results in $[17,42,43]$.

\section{Pre-processing}

The author had the opportunity to test the reconstruction technique on real measurements. However, the acquired physical projections were affected by a number of distortions caused by the physical properties of the imaging system. To lessen the degradations, a series of pre-processing steps were carried out that could correct the major problems identified. The benefits of the pre-processing steps were 
proven via the classical FBP reconstructions of a VIDICON tube, where the author introduced two new pre-processing steps. The intensity correction equalized the total intensities in the projections that corrected the varying flux occurred during the acquisition, while the motion correction could be applied when the projections were the translated and/or rotated versions of the expected images.

The results were published in $[11,52]$ by the author.

\section{Applications}

After the projections were prepared for reconstruction, the author often encountered the problem that the attenuation coefficients of the materials constituting the object were unknown, but the literature attenuation values could not be used due to the polychromaticity of the projections beams. Since having a known set of intensity levels is one of the basic DT assumptions, a technique had to be devised to estimate the levels for the image reconstructions. The intention was to get estimates for them from the accumulation points in the histogram generated by the pixel-based reconstruction, employing the smoothing term and using an enlarged number of intensity levels.

The first real applications were performed on three reference cylinders containing bores of different depths. The objects had the same and known geometry, but three different radiation sources (X-ray, gamma-ray and neutron) were applied for imaging the cylinders. All the projection sequences were affected by several distortions, but most of them could be reduced by using an adequate pre-processing step. In order to compare the DT results with the classical ones, both FBP and ART reconstructions were generated using the widely applied and accepted SNARK reconstruction framework. In general, we found that the DT reconstruction outperformed the classical methods in cases where there were too few projections available. Additionally, if the goal of the reconstruction was to carry out a 3-dimensional model from the results, DT yielded more suitable slices than FBP or ART did. The latter two produced streaky slices that could be softened by smoothing techniques, but the smoothing operator destroyed the region borders and sharp edges became almost unidentifiable.

The author was also supplied with a real (non-reference) object, which was a boron-carbide control rod of an atomic reactor. The task was to identify possible helium accumulations in the lower section of the rod. Although the object contained few materials, their homogeneous distribution could not be guaranteed, so attenuation coefficients and the corresponding discrete set of intensity levels could not be determined. Instead, the author applied 256 intensities along with the smoothness penalty, and then built a 3-dimensional model from the reconstruction results. In this way, the helium bubbles became clearly visible, which was persuasive proof for the physicists and justified their original suppositions.

The author also reconstructed a cardiac pacemaker battery composed of two materials, but the homogeneity of materials could again not be presumed. The aim was to confirm the assumption that the intrinsic part, containing the electrically charged material, had a highly irregular distribution. The DT method managed to 
prove this suspicion via a volume-rendered model, even when only 10-20 projections were provided for the reconstruction.

The author also participated in the development of the DIRECT framework, which is a programming environment to evaluate discrete tomographic techniques. He developed an XSD-based tool to perform grammatic and semantic checks on the DIRECT data files and an XSL/XSLT data converter to enable the data files be visualized in Web browsers. Then the pixel-based method was incorporated into the DIRECT system and published via the DIRECT Web interface.

The author published his results in $[13,17,42,43,52,53]$.

\section{Conclusions}

A new pixel-based DT technique was developed that is suitable for reconstructing objects comprising a small number of homogeneous materials from a few projections. The author inspected the capabilities of the technique on software as well as physical phantoms, and also tested it using real physical measurements. In conclusion one can say that the pixel-based DT method can produce acceptable reconstruction results, even if the classical ones fail when there is a small number of projections. Under such circumstances, the DT technique reflects the real absorption values more properly than FBP and ART, because it cannot show false intensity levels. This fact gives the pixel-based technique an advantage especially for 3-dimensional visualization, when ART and FBP do not perform well.

\section{Key points of the dissertation}

\section{The reconstruction method and simulations}

The results were published in [42, 43] and in a book chapter [17].

I/1. The author devised and developed a new pixel-based DT reconstruction technique that is suitable for reconstructing discrete images containing a few intensity levels from a limited number of parallel projections. In order to evaluate the technique on simulated data, he also implemented a parallel beam projection system to generate tomographic projections for arbitrary grey-level images. [17, 42] (sections 2.3 and 3.1)

I/2. The author analyzed the input parameters, and determined a possible set-up of initial reconstruction arguments. In a simulation environment, the author tested the pixel-based reconstruction technique to see how it performed when its parameters were changed within some reasonable range. The subjects of the investigation were the number of projections used for a reconstruction, the initial temperature, the cooling factor, the termination criterion, the variance needed to determine the equilibrium state, and the amount of noise added to the projections. In addition, he also tested whether the method displayed 
any sensitivity to the geometrical structure of the object to be reconstructed. $[17,42]$ (sections 3.2.3 and 3.3)

I/3. For the simulation of the greatest distorting effect of real measurements, the author developed a noise generator, which was designed to corrupt the perfect projections by additive Gaussian noise. Since the results reflected a strong sensitivity to statistical noise, he proposed, developed, and tested a smoothness prior as a regularization term in the objective functional. [43] (Section 3.4)

I/4. The author constructed two possible extensions to enable the technique to reconstruct multi-level discrete images, and tested the extension on 3-level phantoms under ideal noiseless as well as noisy conditions. [43] (Section 3.5)

\section{Pre-processing}

The results were published in $[11,52]$.

II/1. As the tomographic projections are usually corrupted by a number of different effects, the author devised a possible sequence of pre-processing steps for the common distortions encountered in the physical measurements. He also introduced two new pre-processing steps, namely intensity and motion corrections. [52] (Section 4.5)

II/2. The author examined the benefits of utilizing the pre-processing steps on the classical FBP reconstructions of VIDICON tube cross-sections. [11, 52] (Section 4.6)

\section{Applications}

The results were published in $[13,42,43,52,53]$ and in a book chapter [17].

III/1. The author provided and applied a technique that is capable of determining the approximate values of the intensity levels, which are usually unknown in the case of physical examinations. [17] (Section 5.1.2)

III/2. The author performed the pre-processing steps and reconstructed the X-ray, neutron and gamma-ray projections of a Plexiglas, an iron, and an aluminum reference cylinder, respectively. In order to compare the pixel-based method with the classical ones, FBP and ART reconstructions were also constructed using the SNARK93 programming system. [43, 52] (Chapter 5)

III/3. Within the cooperation of the Hahn-Meitner Institute (Berlin), the author reconstructed a cardiac pacemaker battery from a limited number of X-ray projections, where the homogeneity of the materials could not be assumed. Based on the reconstructed cross-sections, the author constructed a spatial model, which clearly revealed the presumed irregular distribution of the electrically charged intrinsic material. [42] (Section 6.1) 
III/4. The author performed reconstructions from a small number of neutron projections of a boron-carbide control rod provided by the Hungarian Academy of Sciences KFKI Atomic Energy Research Institute (Budapest). He also constructed a 3-dimensional visualization of the reconstructed cross-sections and confirmed the irregular absorber distribution as well as the helium accumulations in the lower section of the rod. [13] (Section 6.2)

III/5. The author participated in the development of the DIRECT system, integrated the reconstruction method with the DIRECT framework, and published the pixel-based technique via the DIRECT Web interface. [53] (Chapter 7) 



\section{Összefoglaló magyar nyelven}

A diszkrét tomográfia a képfeldolgozás egy viszonylag új területe, és mint ilyen, még nem bővelkedik a valós alkalmazásokban. A jelen tézisben tárgyalt kutatás célja egy új diszkrét tomográfiai rekonstrukciós technika kifejlesztése volt, általában kevés anyagfajtát tartalmazó ipari tárgyak néhány vetületből történő rekonstruálására.

\section{Szimulációk}

Az elméleti alapok, valamint a rekonstrukciós módszer kidolgozása után a szerző elsőként az ideális és legegyszerűbb bináris eset szimulációs vizsgálatát végezte el zajtalan vetületekből. Ennek célja a szimulált hűtés paraméterezésével kapcsolatos tapasztalatok gyújtése, illetve a kezdeti rekonstrukciós paraméterek és egy hútési ütemezés meghatározása volt. Ezen ismeretek hiányában, a paraméterek helytelen megválasztásával, a rekonstrukciók szélsőségesen hosszú ideig futhatnak, vagy a korai terminálással megrekedhetnek egy lokális minimumban. Mindazonáltal a paraméterek körültekintő beállításával majdnem mindig jó rekonstrukciós eredmények érhetők el.

A valós fizikai körülmények közelítésére egy statisztikai alapú zajgenerátor került beépítésre a szimulációs rendszerbe, amely additív normális eloszlású zajjal terheli a generált vetületeket. Zajos körülmények között a vetületek általában nem tekinthetők konzisztenseknek, így tökéletes rekonstrukciós eredmény (amikor a célfüggvény felveszi a 0 értéket) sem állítható elő mint zajtalan esetben. Ahhoz, hogy a zaj által torzított rekonstrukciós képek minősége javuljon, a szerző kiterjesztette a célfüggvényt egy simasági regularizációs taggal, amely előnyben részesíti a homogén régiókat tartalmazó képrekonstrukciókat az inhomogénekkel szemben. Ez sokszor helytálló feltételezésnek tekinthető az ipari objektumok estében. A bonyolultabb, több anyagfajtát tartalmazó objektumok rekonstruálására a szerző ugyanitt megadja a rekonstrukciós módszer egy lehetséges kiterjesztését, amellyel a binárisnál több intenzitásszintet tartalmazó diszkrét képek rekonstruálása is lehetségessé válik.

A szerző az eredményeket a [42, 43] cikkekben és a [17] könyvfejezetben publikálta. 


\section{Előfeldolgozás}

A szerzőnek lehetősége nyílt arra, hogy a rekonstrukciós módszert valós vetületi képeken is tesztelje. A fizikai projekciókat azonban gyakran éri számos, a képalkotó rendszer fizikai sajátosságaival magyarázható torzító hatás, mely hatások csökkentésére előfeldolgozási lépések egy lehetséges sorozatát dolgozta ki és valósította meg a szerző. A korrekciók rekonstrukciós képekre gyakorolt jótékony hatásai egy VIDOCON cső klasszikus szűrt visszavetítéssel (FBP) kapott eredményein keresztül kerültek bemutatásra. A szerző itt két új előfeldolgozási lépést is megadott. Az intenzitás korrekció a felvételek készítése során fellépő fluxusingadozás hatását javította, míg a mozgáskorrekció akkor volt használható, amikor a projekciók az elvárt vetületek helyett azok eltolt és/vagy elfogatott változatát tartalmazták.

A szerző az eredményeket a $[11,52]$ közleményekben publikálta.

\section{Alkalmazások}

A vetületek előkészítése után gyakran adódott a probléma, hogy a rekonstrukció során használandó intenzitás értékek ismeretlenek voltak, meghatározásukra viszont az irodalmi elnyelődési együtthatók nem voltak alkalmasak az akvizíció során alkalmazott sugárzás polikromatikus tulajdonsága miatt. Mivel azonban a DT egyik alapfeltétele ezen intenzitásszintek pontos ismerete, szükség volt egy módszer kidolgozására az alkalmazandó szürkeségi szintek becslésére. Erre a célra a szerző megvalósított egy technikát, amely a rendelkezésre álló vetületekből, az indokoltnál nagyobb számú (például 256) intenzitásszint használatával, valamint a simasági büntető tag bekapcsolásával végez rekonstrukciót. Az így kapott rekonstruált kép hisztogramjának torlódási pontjaiból meghatározhatók az intenzitásszintek közelítő értékei.

A pixel-alapú technikát elsőként három, különböző mélységű furatokat tartalmazó referencia hengerre alkalmazta a szerző. A hengerek ismert, azonos geometriájú tárgyak voltak, melyeket gamma, röntgen és neutron sugárzással világítottak át. A különböző modalitásoknak tulajdoníthatóan minden vetületi sorozaton számos torzítás volt beazonosítható, de legtöbbjük jól korrigálható volt a megfelelő előfeldolgozási lépéssel.

A klasszikus módszerek eredményeivel való összehasonlítás kedvéért, a szerző FBP és ART rekonstrukciókat is végzet a SNARK93 rekonstrukciós keretrendszer segítségével. A DT rekonstrukciók elvégzése és az eredmények elemzése után általánosságban elmondható, hogy a pixel-alapú technika kevés rendelkezésre álló vetület esetén jobb eredményt szolgáltat a klasszikus rekonstrukcióknál. Továbbá, amikor az ilyen körülmények között végzett rekonstrukció végső célja egy térbeli modell megalkotása volt, akkor kizárólag a DT módszer eredményezett erre alkalmas keresztmetszeti szeleteket. Ugyanezekben ez esetekben az FBP és ART eredményeket a felhasznált vetületek kis számából eredő, rekonstrukciókban megjelenő sávok rontották le. Ezek simítási technikákkal gyengíthetők lettek volna, viszont a simítás a régiók határait is elmosta és beazonosíthatatlanná tette. 
A szerző rendelkezésére állt egy atomreaktorokban használt bór-karbid moderátor rúdról készült vetületi sorozat is. A feladat a rúd alsó szekciójában feltételezett hélium felhalmozódás kimutatása volt. Bár a tárgy csak néhány anyagfajtát tartalmazott, ezek homogenitása nem volt garantálható, így a diszkrét elnyelődési együtthatók meghatározása sem volt lehetséges. Ezért a szerző a rekonstrukciót 256 intenzitásszinttel és bekapcsolt simasági regularizációs taggal végezte el. A kapott keresztmetszeti szeletekből felépített háromdimenziós modellben meggyőzően, tisztán láthatóvá váltak a hélium buborékok, igazolva ezzel a fizikusok eredeti sejtését.

Ugyanezen technikával végzett a szerző sikeres rekonstrukciót egy két anyagfajtát tartalmazó pészméker akkumulátoron, mely esetében ugyancsak az objektumot felépítő anyagok inhomogenitása volt feltételezhető. A vizsgálat konkrét célja az akkumulátor belső részében elhelyezkedő töltéshordozó anyag irreguláris eloszlásának kimutatása volt, mely a pixel-alapú módszer kimenetéből megkonstruált térbeli modell segítségével azonnal igazolható volt.

A szerző részt vett a DIRECT keretrendszer fejlesztésében, ami egy diszkrét tomográfiai rekonstrukciós módszerek kiértékelésére kifejlesztett program környezet. Ugyanitt elkészített egy XSD alapú grammatikai és szemantika ellenőrző eszközt, valamint egy XSL/XSLT konvertálót, amely lehetővé teszi a DIRECT adat fájlok Web böngészőben történő megjelenítését. Végezetül a pixel-alapú technika beépítésre került a DIRECT rendszerbe, és jelenleg is elérhető a DIRECT Web interfészén keresztül.

A szerző az elért eredményeket a [13, 42, 43, 52, 53] cikkekben és a [17] könyvfejezetben tette közzé.

\section{Konklúziók}

Egy új pixel-alapú DT technika került megvalósításra, amely kevés vetületből tud rekonstruálni néhány homogén anyagfajtát tartalmazó objektumokat. A szerző vizsgálta a pixel-alapú technika képességeit szoftveres és fizikai fantomokon egyaránt, továbbá tesztelte a módszert valós vetületi képeken is. A dolgozatban tárgyalt eredmények alapján elmondható, hogy a rekonstrukciós technika akkor is elfogadhatóan jó eredményt ad, amikor a klasszikus módszerek már nem alkalmazhatók a túl kevés rendelkezésre álló vetület miatt. Ilyen körülmények között a pixel-alapú technika jobban tükrözi a valódi elnyelődési együtthatókat mint a klasszikus módszerek, mivel a DT rekonstrukciók nem tudnak hamis intenzitásszinteket eredményezni. Továbbá az így rekonstruált keresztmetszeti szeletekből olyan esetekben is térbeli modell készíthető, amikor az ART és FBP módszerek erre a célra már nem adnak alkalmas eredményt. 


\section{A disszertáció eredményei}

\section{A rekonstrukciós módszer és szimulációk}

Az eredmények a [42, 43] cikkekben és a [17] könyvfejezetben kerültek publikálásra.

I/1. A szerző kidolgozott és megvalósított egy új pixel-alapú rekonstrukciós technikát, amely néhány intenzitásszintet tartalmazó diszkrét képek kevés vetületi képből való rekonstruálására alkalmas. Továbbá a rekonstrukciós technika szimulált adatokon történő tesztelése céljából a szerző kifejlesztett egy szürkeárnyalatos képek párhuzamos vetületeinek generálására felkészített tomográfiai vetítőrendszert. [17, 42] (2.3., 3.1. fejezetek)

I/2. A szerző elemezte és analitikus úton meghatározta a rekonstrukciós technika paramétereinek egy lehetséges kezdeti értékét, amelyek a későbbi szimulációs kísérletek alapját is képezték. A szerző tanulmányozta, hogy az egyes rekonstrukciós paraméterek hangolása hogyan hat a rekonstrukciós technikára és hogyan befolyásolja a rekonstrukció minőségét. A vizsgálatok tárgyát a rekonstrukcióhoz felhasznált vetületek száma, a kezdőhőmérséklet, a hütési tényező, a leállási feltétel és a vetületekhez hozzáadott zaj paraméterek képezték. A szerző ugyanitt vizsgálta a rekonstrukciós módszer rekonstruálandó objektum geometriai struktúrája iránt mutatott érzékenységét is. [17, 42] (3.2.3., 3.3. fejezetek)

I/3. A valós felvételeken előforduló legnagyobb tortzítást okozó hatás szimulálására a szerző kidolgozott és megvalósított egy zajgenerátort, amely a pontos vetületi adatokat additív normális eloszlású zajjal terheli. Mivel a módszer érzékeny a statisztikai zajra, a szerző javasolta, megvalósította és szimulációs adatokon teszelte a simaság a priori információként regularizációs tagba történő beépítését. [43] (3.4. fejezet)

I/4. A szerző megkonstruálta a pixel-alapú technika két lehetséges kiterjesztését azért, hogy az a több intenzitásszintet tartalmazó képek rekonstruálására is alkalmazható legyen. Továbbá ugyanitt rekonstrukciós teszteket végzett háromértékű képeken zajtalan és zajos vetületekből egyaránt. [43] (3.5. fejezet)

\section{Előfeldolgozás}

Az eredmények a $[11,52]$ cikkekben kerültek publikálásra.

II/1. A valós tomográfiai vetületeket érő fizikai hatások torzításának csökkentésére a szerző kidolgozta az előfeldolgozási lépések egy lehetséges sorozatát, melyek közül az intenzitás és a mozgás korrekciót a szerző alkalmazta elsőként. [52] (4.5. fejezet) 
II/2. A szerző az előfeldolgozási lépések rekonstrukcióra gyakorolt pozitív hatását egy VIDICON cső vetületein végzett klasszikus FBP rekonstrukciók kimenetein mutatta be. $[11,52]$ (4.6. fejezet)

\section{Alkalmazások}

Az eredmények a [13, 42, 43, 52, 53] cikkekben és a [17] könyvfejezetben kerültek publikálásra.

III/1. A szerző megalkotott és alkalmazott egy eljárást a valós alkalmazások esetében ismeretlen intenzitásszintek becslésére. [17] (5.1.2. fejezet)

III/2. A szerző a szükséges előfeldolgozási lépések elvégzése után azonos geometriájú plexi, vas és alumínium hengerek röntgen, neutron és gamma vetületein pixel-alapú DT rekonstrukciókat végzett. Emellett az összehasonlíthatóság érdekében elvégezte az FBP és ART rekonstrukciókat is a SNARK93 rekonstrukciós keretrendszer segítségével. [43, 52] (5. fejezet)

III/3. A Berlini Hahn-Meitner Intézettel közösen végzett kísérletben a szerző a pixelalapú módszerrel kevés számú vetületből rekonstruált egy pacemaker akkumulátort, amely esetében a tárgyat alkotó anyagfajták homogenitása nem volt feltételezhető. A szerző a rekonstruált keresztmetszeti szeletekből egy háromdimenziós modellt állított elö, amely több keresztmetszeti szeleten keresztül mutatta a belső töltéshordozó anyag feltételezett irreguláris eloszlását. [42] (6.1. fejezet)

III/4. A szerző kevés számú vetületből rekonstruált egy atomreaktorokban használt bór-karbid moderátor rudat, mely projekciókat a Magyar Tudományos Akadémia KFKI Atomenergia Kutatóintézete bocsátott a rendelkezésünkre. A rekonstruált szeletekből a szerző előállított egy térbeli modellt, melyen keresztül kimutatható volt az abszorber anyag irreguláris eloszlása és a feltételezett hélium buborékok alsó szekciókban való fokozott jelenléte. [13] (6.2. fejezet)

III/5. A szerző részt vett a DIRECT rendszer kifejlesztésében, továbbá integrálta a pixel-alapú módszert a DIRECT rendszerbe és elérhetővé tette a DIRECT Web interfészén keresztül. [53] (7. fejezet) 